ANNOTATED BIBLIOGRAPHY OF THE HYDROLOGY, GEOLOGY, AND GEOTHERMAL RESEARCH OF THE JEMEZ MOUNTAINS AND VICINITY, NOR TH-CENTRAL NEW MEXICO

\author{
By Cynthia G. Abeyta and Bruce M. Delaney
}

U.S. GEOLOGICAL SURVEY

Open-File Report 85-83

Prepared in cooperation with the U.S. BUREAU OF INDIAN AFFAIRS and the NEW MEXICO STATE ENGINEER OFFICE

Albuquerque, New Mexico

1986 


\author{
UNITED STATES DEPARTMENT OF THE INTERIOR \\ DONALD PAUL HODEL, Secretary \\ GEOLOGICAL SURVEY \\ Dallas L. Peck, Director
}

\footnotetext{
For additional information write to:
}

District Chief

U.S. Geological Survey Water Resources Division 505 Marquette NW, Room 720

Albuquerque, New Mexico 87102

\section{Copies of this report can be purchased from:}

Open-File Services Section Branch of Distribution

U.S. Geological Survey, MS 306 Box 25425, Federal Center Denver, Colorado 80225

(303) 236-7476 
CONTENTS

Page

Abstract $\ldots \ldots \ldots \ldots \ldots \ldots \ldots \ldots \ldots \ldots \ldots \ldots \ldots \ldots \ldots \ldots \ldots \ldots \ldots \ldots \ldots \ldots$

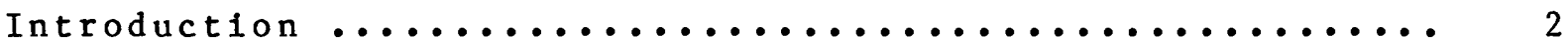

Bibliography $\ldots \ldots \ldots \ldots \ldots \ldots \ldots \ldots \ldots \ldots \ldots \ldots \ldots \ldots \ldots \ldots \ldots \ldots \ldots$

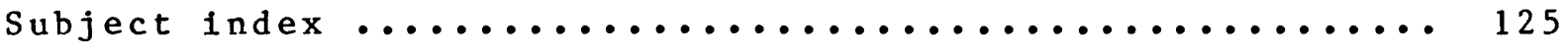

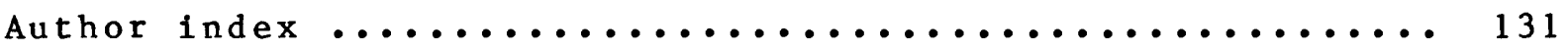

\section{F I GURES}

Figure 1. Map showing location of the Rio Grande rift and the Jemez lineament in New Mexico ...... 3

2. Map showing Jemez Mountains study area ....... 4 


\title{
ANNOTATED BIBLIOGRAPHY OF THE HYDROLOGY, GEOLOGY, AND GEOTHERMAL RESEARCH OF THE JEMEZ MOUNTAINS AND VICINITY, NORTH-CENTRAL NEW MEXICO
}

\author{
By Cynthia G. Abeyta and Bruce M. Delaney
}

\author{
AB S T RACT
}

The Jemez Mountains volcanic complex, located in north-central New Mexico at the intersection of the Rio Grande rift and Jemez lineament, is a potential location for geothermal energy exploration. This bibliography lists selected publications pertaining to the geology, hydrology, geochemistry, geothermometry, geophysics, ecology, and geothermal and hydrologic modeling aspects of the Jemez region. The bibliography is composed of 795 citations with annotations and subject and author indexes. 
The Jemez Mountains, a large dormant volcanic complex, are in north-central New Mexico at the intersection of the northtrending Rio Grande rift and the northeast-trending Jemez lineament ( $f$ igs. 1 and 2). The region is a potential location for geothermal exploration, as indicated by several boiling pools of acid-sulfate muddy water, fumaroles, and the many hot springs in the area.

This bibliography was compiled as part of a study by the U.S. Geological Survey to evaluate potential hydrologic effects of geothermal power development in the Jemez Mountains. The U.S. Bureau of Indian Affairs and New Mexico State Engineer office cooperated with the U.S. Geological Survey in conducting the study.

Criteria used for selecting publications were: (1) Application of geology, hydrology, geochemistry, geothermometry, geophysics, ecology, and geothermal and hydrologic modeling to the Jemez Mountains and vicinity; and (2) relative studies of similar environments or topics, for example: "volcanic rocks as geologic guides to geothermal exploration and evaluation."

The main body of the bibliography consists of 795 citations listed alphabetically and chronologically. Each citation is followed by an annotation in the following categories:

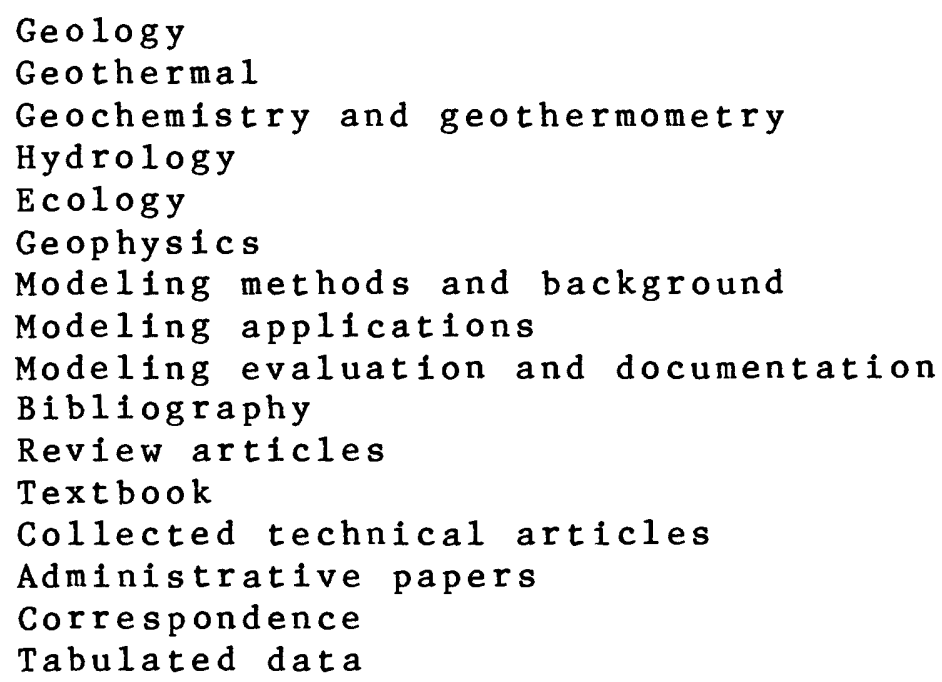




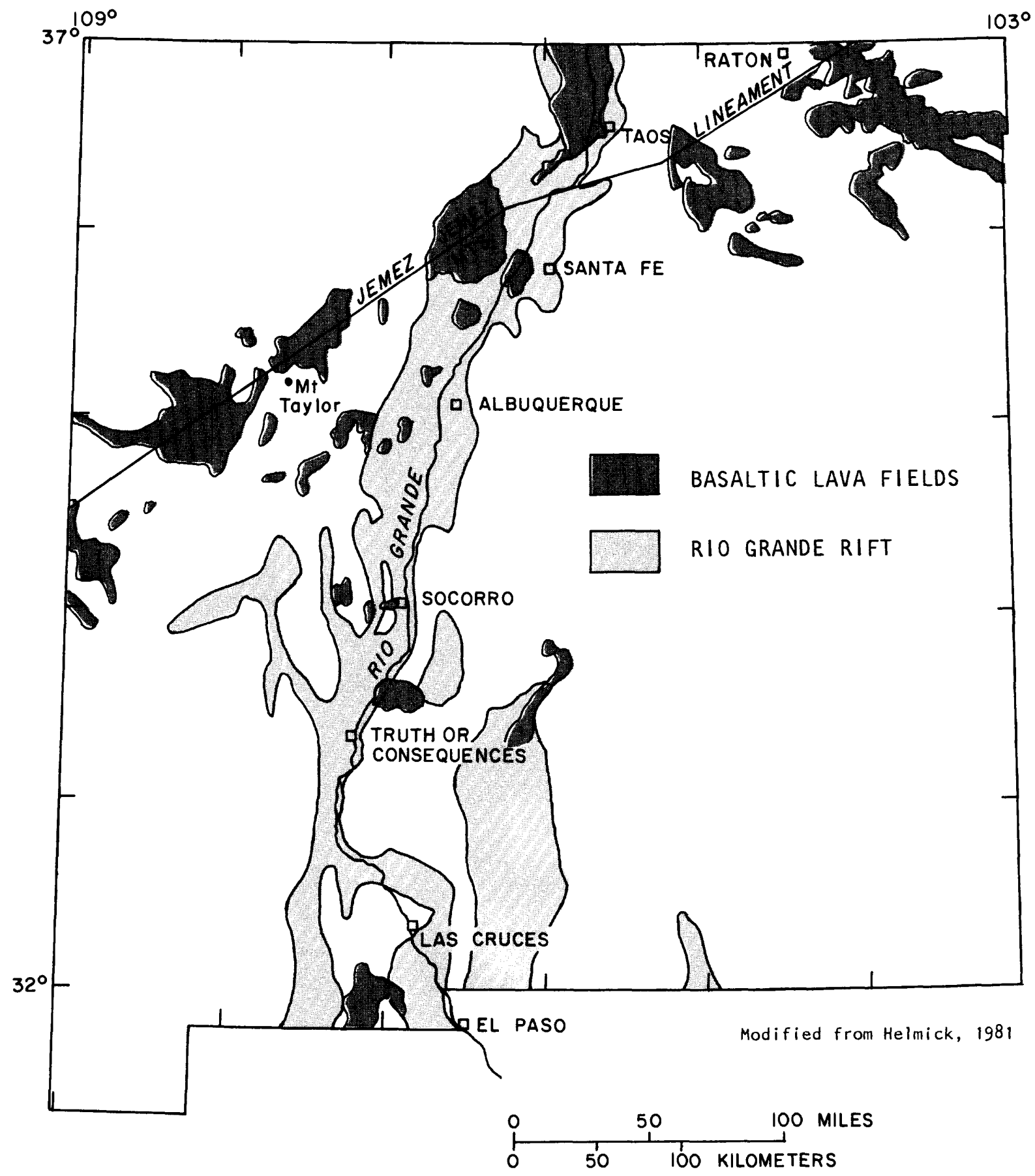

Figure 1.--Location of the Rio Grande rift and the Jemez lineament in New Mexico. 

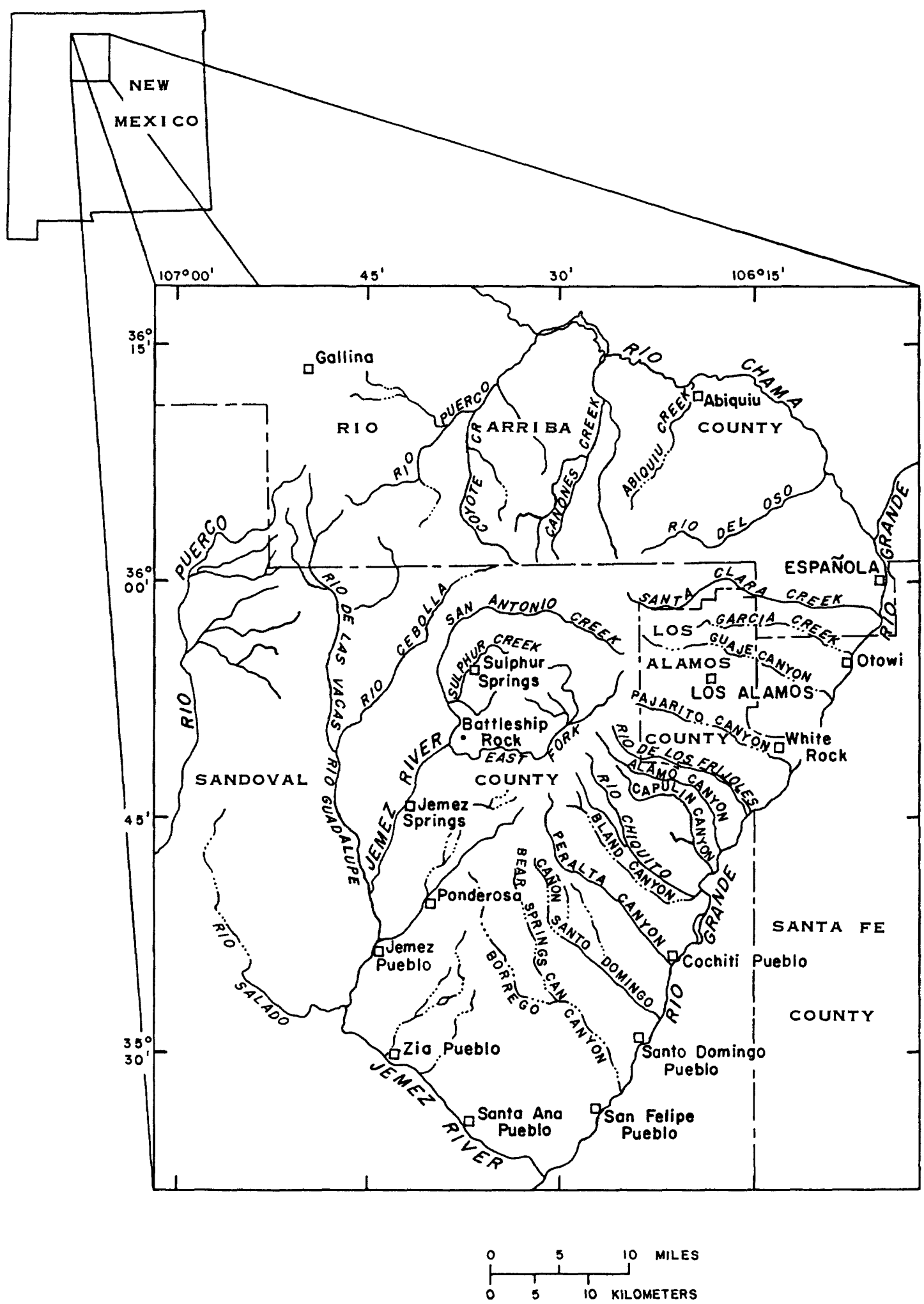

Figure 2.--Jemez Mountains study area. 
Following the bibliography are subject and author indexes; the numbers refer to the citations listed in the bibliography. The subject index includes the categories listed on page 2 . 
B I BL IOGRAPHY

1. Aamodt, R. L., 1973, Insitu measurement of earth stress and apparent surface energy in granite: American Geophysical Union Transactions, v. 54, no. 4, p. 1209.

Geology, Hydrology, Geophysics.

2. 1973, The Los Alamos Scientific Laboratory hot dry rock geothermal energy program, in Papers presented at energy crisis symposium, Albuquerque, New Mexico, 1973: New Mexico Bureau of Mines and Mineral Resources Circular 140 , p. 106-107.

Geology, Geothermal, Geochemistry and geothermometry, Hydrology, Geophysics.

3. 1976, Hydraulic fracturing in and communication between two adjacent wellbores [abs.]: American

Geophysical Union Transactions, v. 57, no. 4, p. 349 .

Geology, Geothermal, Hydrology, Geophysics.

4. Aamodt, R. L., and Potter, R. M., 1978, Anomalous

fracture-extension pressure in granitic rocks: Los Alamos

Scientific Laboratory Report LA-UR-78-548, 24 p.

Geology, Geophysics.

5. Abrahams, J. H., Jr., Weir, J. E., Jr., and Purtymun, W. D., 1961, Distribution of moisture in soil and near-surface tuff on the Pajarito plateau, Los Alamos County, New Mexico, in U.S. Geological Survey Research, 1961: U.S. Geological Survey Professional Paper 424-D, p. D142-D145. Geology, Hydrology, Tabulated data.

6. Abrahams, J. H., Jr., Ba1tz, E. H., and Purtymun, W. D., 1962 , Movement of perched ground water in alluvium near Los Alamos, New Mexico, in U.S. Geological Survey

Research, 1962 : U.S. Geological Survey Professiona1 Paper 450-B, p. B 93-B94.

Geology, Hydrology. 
7. Ahearne, John, 1979, Fenton Hil1, drilling for energy at 13,000 feet, in Expanding the Hot, Dry Rock Program: Los A1 amos Scientific Laboratory LASL-79-60, p. 2-6. Geothermal, Geophysics.

8. Aiken, C. L. V., Laughlin, A. W., and West, F. G., 1981 , Residual Bouguer gravity anomaly map of northern New Mexico: Los Alamos Scientific Laboratory LA-6737-MAP, scale $1: 500,000,1$ sheet.

Geophysics.

9. Albright, J. N., 1975, A new and more accurate method for the direct measurement of earth temperature gradients in deep boreholes, in Proceedings, Second United Nations symposium on the development and use of geothermal resources, San Francisco, California, USA, May 20-29, 1975: U.S. Government Printing office, v. 2, p. 847-853. Geothermal, Geochemistry and geothermometry, Geophysics.

10 . 1975, Temperature measurements in the Precambrian section of geothermal test hole no. 2: Los Alamos Scientific Laboratory Informa1 Report LA-6022-MS, 11 p. Geothermal, Geochemistry and geothermometry.

11 . 1976, Preliminary seismic mapping of the main fracture in GT-2 [abs.]: American Geophysical Union Transactions, v. 57 , no. 4, p. 349 . Geology, Geophysics.

12. Albright, J. N., Hanold, R. J., and Linville, B., eds., 1976, Seismic mapping of hydraulic fractures made in basement rocks, in Proceedings of the Second ERDA Symposium on Enhanced 011 and Gas Recovery, Tulsa, Oklahoma, Sept. 9-10, 1976: U.S. Energy Research and Development Administration, p. C8.1-C8.13.

Geology, Geophysics.

13. Albright, J. N., and others, in Hot Dry Rock Geothermal Annual Report for FY-1977: Laboratory Progress Report Hydrology, Ecology.
1978 , Environmental studies, Energy Development Project, Los Alamos Scientific LA-7 109-PR, P. 249-267. 
14. Albuquerque Journa1, 1983, Jemez hot-rock project, biggest ever: Albuquerque Journa1, Albuquerque, New Mexico, December $13,1983, \mathrm{p} . \mathrm{A}-1, \mathrm{~A}-5$.

Geotherma1, Geophysics.

15. A1drich, M. J., Jr., 1982, Orientation of least-principal horizontal stress - Arizona, New Mexico, and the Trans-Pecos area of west Texas (stress data and references): Los Alamos National Laboratory LA-8158-MAP, 19 p. and 1 sheet.

Geology, Geophysics, Tabulated data.

16. Ander, M. E., 1981, Geophysical study of the crust and upper mantle beneath the Central Rio Grande Rift and adjacent Great Plains and Colorado Plateau: Los Alamos Scientific Laboratory Thesis LA-8676-T, 218 p. Geology, Geothermal, Geophysics, Tabulated data.

17. Ander, M. E., and Huestis, S. P., 1983, Recent mafic intrusion beneath the Lucero Uplift, New Mexico and its possible structural relationship to a northeast-trending Precambrian shear system: submitted to Geological society of America Bulletin (in preparation). Geology, Geophysics.

18. Ander, M. E., and others, 1980 , Magnetotelluric/audiomagnetotelluric study of the Zuni hot dry rock geothermal prospect, in Preprints

Geothermal Resources Council Annual Meeting, Salt Lake City, Utah, September 9-11, 1980: Los Alamos Scientific Laboratory Report LASL-80-36, p. 25-28.

Geothermal, Geophysics, Tabulated data.

19.

1981 , Geologic and geophysical investigations of the Zuni-Bandera volcanic field, New Mexico: Los Alamos Scientific Laboratory Informal Report LA-8827-MS, 34 p. Geology, Geophysics, Tabulated data.

20. Anderson, J. B., 1970, Stratigraphy of the western margin of the Nacimiento Uplift [abs.]: Geological Society of America Rocky Mountain Section Abstracts with Programs for $1970, p \cdot 324$.

Geology 
21 . 1970 , Structure and stratigraphy of the western margin of the Nacimiento Uplift, New Mexico: Albuquerque, N. Mex., University of New Mexico, M.S. thesis, 44 p. Geology.

22. Anderson, R. Y., 1961, Physiography, climate and vegetation of the Albuquerque Region, in Guidebook of Albuquerque Country: New Mexico Geological Society, 12 th Field Conference, p. 63-71. Geology, Hydrology, Ecology.

23. Andrews, Bob, 1982, Briefing notes on the nationa1 continental scientific research drilling program - For the Valles Caldera workshop, Los Alamos, New Mexico, 5-7 october 1982: National Academy of Sciences, Continental Scientific Drilling Committee, Washington, D.C., Draft document 0963A, $16 \mathrm{p}$.

Geology, Geothermal, Geophysics.

24. Andrews, Charles, n.d., Sensing and predicting thermal pollution of groundwater: Madison, Wis., University of Wisconsin, 5 p. Hydrology, Ecology, Modeling methods and background, Modeling applications.

25. Anonymous, 1961, Structural problems of the Rio Grande Trough in the Albuquerque Country, in Guidebook of Albuquerque Country: New Mexico Geological Society, 12 th Field Conference, p. 144-147.

Geology.

26. Applied Geophysics, Inc., 1974, Mercury soil gas survey, Baca Prospect, Sandova1 County, New Mexico: consultant report for Union Oil Company of California, Union Geothermal Division, Los Angeles, California, 20 p. Geothermal, Geochemistry and geothermometry, Hydrology.

27. Apt, K. E., and Lee, V. J., 1976, Environmenta1 surveillance at Los Alamos during 1975: Los Alamos Scientific Laboratory Informal Report LA-6321-MS, 54 p. Hydrology, Ecology, Tabulated data. 
28. Armenta, Eddie, Icerman, Larry, and Starkey, Arlene, 1981 , Geothermal test well drilling program for the viliage of Jemez Springs, New Mexico: New Mexico Energy Research and Development Institute EMD 2-67-2537, 29 p.

Geology, Geothermal, Geochemistry and geothermometry, Hydrology, Tabulated data.

29. Armstead, H. C. H., 1973, Geothermal energy: Paris, France, UNESCO Press, 186 p.

Geology, Geothermal, Hydrology, Bibliography, Textbook, Collected technical articles, Tabulated data.

30. Armstrong, A. K., 1955, Preliminary observations on the Mississippian System of northern New Mexico: New Mexico Bureau of Mines and Mineral Resources Circular 39, 49 p. Geology.

31. Armstrong, A. K., and Mamet, B. L., 1974, Biostratigraphy of the Arroyo Peñasco Group, Lower Carboniferous (Mississippian), north-central New Mexico, in Guidebook of Ghost Ranch: New Mexico Geological Society, $25 \mathrm{th}$ Field Conference, p. 145-158.

Geology.

32. Armstrong, R. L., 1969, Geochronology of the eastern Basin and Range Province, eastern Nevada, western Utah, and the Colorado Plateau, Utah, Colorado, Arizona, and New Mexico: Geological Society of America Rocky Mountain Section Abstracts with Programs for 1969, part 5, p. 2 . Geology.

33. Atkinson, P. G., 1980, Geothermal reservoir initial state, Baca Location No. 1, New Mexico, Redondo Creek Field: Geothermal Resources Council Transactions, v. 4, p. 435-438.

Geothermal, Hydrology. 
34. Atkinson, P. G., and Galati, M. S., 1979, Status report on geothermal development in the Valles Caldera, New Mexico, in Proceedings, Fifth Workshop, Geothermal Reservoir Engineering, December 12-14, 1979: Stanford, Calif., Stanford University SPG-TR-40, p. 257-260. Geothermal.

35. Bachman, G. 0., and Mehnert, H. H., 1978, New K-AR dates and the late Pliocene to Holocene geomorphic history of the central Rio Grande region, New Mexico: Geological Society of America Bulletin, v. 89, no. 2, p. 283-292. Geology, Geochemistry and geothermometry, Tabulated data.

36. Bailey, R. A., 1954, Fusion of arkosic sandstone by intrusive andesite, Valles Mountain, New Mexico: Ithaca, N. Y., Cornell University, unpublished M.S. thesis, $87 \mathrm{p}$.

Geology.

37 .

1959, Contact fusion of argillaceous and arkosic sediments by an andesite intrusion, Valles Mountains, New Mexico [abs.]: Geological Society of America Bulletin, v. 70 , no. 12, pt. 2, p. 1565 .

Geology.

38 .

1961, Hot springs and solfataric areas in the Valles Caldera, Jemez Mountains, New Mexico: U.S. Geological Survey open-File Report 61-4, 1 sheet. Geology, Geothermal, Hydrology.

39 .

1976, On the mechanisms of postsubsidence, central

doming and volcanism in resurgent calderns [abs.]:

Geological Society of America Rocky Mountain Section Abstracts with Programs for 1976, v. 8, no. 5, p. 567. Geology, Geophysics.

40. Bailey, R. A., and Smith, R. L., 1978, Volcanic geology of the Jemez Mountains, New Mexico, in Guidebook to the Rio Grande Rift in New Mexico and Colorado: New Mexico Bureau of Mines and Mineral Resources Circular 163, p. 184-195.

Geology, Geothermal, Geophysics, Collected technical articles. 
41. Bailey, R. A., Smith, R. L., and Ross, C. S., 1969, Stratigraphic nomenclature of volcanic rocks in the Jemez Mountains, New Mexico, in Contributions to Stratigraphy: U.S. Geologica1 Survey $\overline{B u} 1$ letin 1274-P, p. P1-P19. Geology.

42. Ba1agna, J. C. R., and Vida1e, Rosemary, 1976, Geotherma1 chemistry activities at LASL. January--December 1975: Los Alamos Scientific Laboratory Progress Report $\mathrm{LA}-6448-\mathrm{PR}, 30 \mathrm{p}$. Geothermal, Geochemistry and geothermometry, Hydrology.

43. Baldridge, W. S., 1979, Petrology and petrogenesis of Plio-Pleistocene basaltic rocks from the central Rio Grande Rift, New Mexico, and their relation to rift structure, in Rieker, R. E., ed., Rio Grande RiftTectonics and Magmatism: American Geophysical Union, p. 323-353. Geology, Geophysics.

44. Baldridge, W. S., Perry, F. V., and Gladney, E. S., 1980, Petrology of the Cat Hills and Lucero Volcanic Fields of central New Mexico [abs.]: American Geophysical Union Transactions, v. 61 , no. 46, p. 1141 .

Geology.

45. Bal1, J. W., and others, 1975, Sampling and preserving techniques for waters in geysers and hot springs, in Proceedings of the first workshop on sampling geothermal effluents, october 20-21, 1975 , Las Vegas, Nevada: Environmenta1 Protection Agency Report EPA-600/9-76-011, p. 218-234. Geothermal, Geochemistry and Geothermometry, Hydrology.

46. Baltz, E. H., 1967, Stratigraphy and regional tectonic implications of part of Upper-Cretaceous and Tertiary rocks, east-central San Juan Basin, New Mexico: U.S. Geological Survey Professional Paper 552, 101 . Geology. 
47. Baltz, E. H., Abrahams, J.H., Jr., and Purtymun, W. D., 1963, Preliminary report on the geology and hydrology of Mortandad Canyon near Los Alamos, New Mexico, with reference to disposal of liquid, low-level radioactive waste: U.S. Geological Survey Open-File Report 63-6, $105 \mathrm{p}$.

Geology, Hydrology, Ecology, Tabulated data.

48. Barker, Colin, 1976, Gas content of quartz from the GT-2 geothermal test hole, Fenton Hill, New Mexico [abs.]: American Geophysical Union Transactions, v. 57, no. 4, p. 353 .

Geology, Geothermal, Geochemistry and geothermometry, Hydrology, Geophysics.

49. Beaumont, E. C., and Read, C. B., eds., 1960, Guidebook of Rio Chama Country: New Mexico Geological Society, 11 th Field Conference, 129 p.

Geology, Collected technical articles.

50. Becker, N. M., Purtymun, W. D., and Ballance, W. C., 1981, Aquifer evaluation at Fenton Hill, October and November 1980: Los Alamos National Laboratory LA-8964-MS, 15 p. Geology, Geochemistry and geothermometry, Hydrology, Tabulated data.

51. Beltrame, R. J., and others, 1976, Volatiles released by step-heating a cortierite to 1200 degrees C. [abs.]: American Geophysical Union Transactions, v. 57, no. 4, p. 352 .

Geology, Geothermal, Geochemistry and geothermometry, Hydrology, Geophysics.

52. Berger, L. R., 1981, Baca geothermal demonstration project, Jemez watershed monitoring program, water year 1979-1980: Union Geothermal Company of New Mexico (Union 0il Company of California, Union Geothermal Division, Los Angeles, California), 9 p., tables.

Hydrology, Tabulated data. 
53. Berry, G. W., Grim, P. J., and Ike1man, J. A., compilers, 1980 , Thermal springs list for the United States:

National Oceanic and Atmospheric Administration Key to Geophysical Records Documentation No. 12, 59 p.

Geothermal, Tabulated data.

54. Best, M. G., 1975, Migration of hydrous fluids in the upper mantle and potassium variation in calc-alkalic rocks:

Geology, v. 3, no. 8, p. 429-432.

Geology, Geochemistry and geothermometry, Geophysics.

55. Bickford, M. E., and Wetheri11, G. W., 1965 , Compilation of Precambrian geochronological data for North America, in Geochronology of North America: National Academy of Sciences, National Research Council Publication 1276 , Nuclear Science Series Report 41, p. 21-179.

Geology.

56. Bingler, E. C., 1964, Superposed folding in the Precambrian of the La Madera Quadrangle, Rio Arriba County, New Mexico [abs.]: Geological Society of America Special Paper 76, p. 265 .

Geology.

57. 1965, Precambrian geology of La Madera Quadrangle, Rio Arriba County, New Mexico: New Mexico Bureau of Mines and Mineral Resources Bulletin $80,132 \mathrm{p}$. Geology.

58. 1968, Geologic map of El Rito Quadrangle, Rio Arriba County, New Mexico: New Mexico Bureau of Mines and Mineral Resources Geologic Map GM-20, scale $1: 24,000,1$ sheet.

Geology.

59.

1968, Geologic map of Valle Grande Peak Quadrangle, Rio Arriba County, New Mexico: New Mexico Bureau of Mines and Mineral Resources Geologic Map GM-21, scale 1:24,000, 1 sheet.

Geology. 
60 . 1968, Geology and mineral resources of Rio Arriba County, New Mexico: New Mexico Bureau of Mines and Mineral Resources Bulletin 91, 158 p. Geology, Tabulated data.

61. Birdseye, H. S., 1971, Geotherma1 power in New Mexico: New Mexico Academy of Sciences Bulletin, v. 12, no. 1, p. 1-8. Geothermal.

62. Birdwe11 Division, 1972, Caliper log, Jemez Granite No. 1, Jemez Plateau, Sandoval County, New Mexico, 6-3-72 [Field print for Los Alamos Scientific Laboratory]: Tulsa, okla., Birdwell Division, 1 sheet.

Geology, Geophysics, Tabulated data.

63. 1972 , Density log, Jemez Granite No. 1, Jemez

Plateau, Sandoval County, New Mexico, 6-3-72 [Field print for Los Alamos Scientific Laboratory]: Tulsa, Okla., Birdwell Division, 1 sheet. Geology, Geophysics, Tabulated data.

64 . 1972 , Nuclear Log, Jemez Granite No. 1, Jemez Plateau, Sandoval County, New Mexico, 6-29-72 [Field print for Los Alamos Scientific Laboratory]: Tulsa, okla., Birdwell Division, 1 sheet. Geology, Geophysics, Tabulated data.

65 . 1972, Temperature $10 \mathrm{~g}$, Jemez Granite No. 1, Jemez

Plateau, Sandoval County, New Mexico, 6-30-72 [Field print for Los Alamos Scientific Laboratory]: Tulsa, Okla., Birdwel1 Division, 1 sheet. Geothermal, Geochemistry and geothermometry, Geophysics, Tabulated data.

66 . 1972, Three-dimensional velocity 1 og, Jemez Granite No. 1, Sandoval County, New Mexico, Run 1 and 2, 6-30-72 [Field print for Los Alamos Scientific Laboratory]: Tulsa, 0kla., Birdwell Division, 1 sheet. Hydrology, Geophysics, Tabulated data. 
67 .

1972, Three-dimensional velocity $10 \mathrm{~g}$, Jemez Granite No. 1, Sandoval County, New Mexico, Run 3 and 4, 6-30-72 [Field print for Los Alamos Scientific Laboratory]: Tu1sa, 0k1a., Birdwe11 Division, 1 sheet. Hydrology, Geophysics, Tabulated data.

68. Black and Veatch Consulting Engineers, 1950, Ground-water observation wells, Los Alamos, New Mexico: consultant report for U.S. Atomic Energy Commission, 28 p. Hydrology.

69. B1ack, B. A., 1975, Structural and stratigraphic implications of surface geology in northern Albuquerque-Belen, Santo Domingo, and southern Española Basins, New Mexico [abs.]: American Association of Petroleum Geologists Bulletin, v. 59, no. 5, p. 905. Geology.

70. B1air, A. G., Tester, J. W., and Mortensen, J. J., 1976, LASL hot dry rock geothermal project, July 1, 1975 - June 30, 1976: Los Alamos Scientific Laboratory Progress Report LA-6525-PR, 238 p.

Geology, Geothermal, Geochemistry and geothermometry, Hydrology, Ecology, Geophysics, Tabulated data.

71. B1air, P. M., and Weinaug, C. F., 1969, Solution of two-phase flow problems using implicit difference equations: Society of Petroleum Engineers Journa1, v. 9 , no. 4, p. 417-424.

Hydrology, Modeling methods and background, Modeling applications, Modeling evaluation and documentation, Tabulated data.

72. Bliss, J. D., 1983, New Mexico-- Basic data for thermal springs and we $11 \mathrm{~s}$ as recorded in GEOTHERM:

U.S. Geological Survey Open-File Report 83-434, 175 p. Geology, Geothermal, Geochemistry and geothermometry, Hydrology, Tabulated data. 
73. Bloodgood, D. W., 1930, The ground water of the middle Rio Grande Valley and its relation to drainage: Las Cruces, N. Mex., New Mexico State University, New Mexico College of Agriculture and Mechanic Arts Bulletin 184, 60 p. Hydrology.

74. Bodvarsson, G. S., O'Sullivan, M. J., and Tsang, C. F., 1980 , The sensitivity of geothermal reservoir behavior to relative permeability parameters, in Proceedings, 6 th Workshop, Geothermal Reservoir Engineering, December 15-16, 1980: Stanford Calif., Stanford University SPG-TR-50, p. 224-237.

Geothermal, Modeling methods and background, Modeling evaluation and documentation.

75. Bodvarsson, G. S., and others, 1980, Preliminary estimation of the reservoir capacity and the longevity of the Baca Geothermal Field, New Mexico: Dallas, Tex., Society of Petroleum Engineers SPE 9273, 12 p. Geothermal, Modeling methods and background, Modeling applications.

76 . 1982, Preliminary studies of the reservoir capacity and the generating potential of the Baca Geothermal Field, New Mexico: Water Resources Research, v. 18, no. 6, p. 1713-1723.

Geology, Geothermal, Geophysics, Tabulated data.

77. Borton, R. L., 1968, General geology and hydrology of north-central Santa Fe County, New Mexico: New Mexico State Engineer office open-file report, 21 p.

Geology, Hydrology.

78 . 1974, A 1 isting of geohydrologic data for 106 exploratory holes drilled by Nuclear Dynamics, Inc. in Rio Arriba, Sandoval and Santa Fe Counties, 1970-1972: New Mexico State Engineer Office open-file report, 9 p. Geology, Hydrology, Geophysics, Tabulated data. 
79 . 1974 , General geology and ground water conditions in the Truchas-Española-Velarde Area of Rio Arriba County, New Mexico, in Guidebook of Ghost Ranch: New Mexico Geological society, 25th Field Conference, p. 351-354. Geology, Hydrology, Tabulated data.

80 . 1978 , Bibliography of ground-water studies in New Mexico, 1873-1977: New Mexico State Engineer Special Publication, $121 \mathrm{p}$. Hydrology, Bibliography.

81 . 1980 , Bibliography of ground-water studies in New Mexico, 1848-1979: New Mexico State Engineer Special Publication, 46 p. Hydrology, Bibliography.

82 . 1983 , Bibliography of ground-water studies in New Mexico, 1903-1982: New Mexico State Engineer Special Publication, 84 p. Hydrology, Bibliography.

83. Boyle, J. M., and Saleem, B. A., 1979, Determination of recharge rates using temperature-depth profiles in wells: Water Resources Research, v. 15, no. 6, p. 1616-1622. Geothermal, Hydrology, Modeling methods and background, Modeling applications.

84. Bredehoeft, J. D., and Papadopulos, I. S., 1965, Rates of vertical groundwater movement estimated from the earth's thermal profile: Water Resources Research, v. 1, no. 2, p. 325-328.

Geothermal, Hydrology, Modeling methods and background.

85. Bridwell, R. J., and others, 1975, The Rio Grande Rift in Cenozoic continental rift tectonics: Los Alamos Scientific Laboratory LA-UR-75-2136, 14 p. Geology. 
86.

1975, Finite element modeling of heat flow across

the Rio Grande Rift near the Valles Caldera [abs.]:

Geological Society of America Abstracts with Programs, v. 7, no. 7, p. 1009-1010.

Geology, Geothermal, Geophysics, Modeling applications.

87. Brittenham, T. L., Williams, R. E., Rowley, J. C., and Neudecker, J. W., 1980, Directional drilling operations hot dry rock well EE-2, in Preprints, Geothermal

Resources Council Annual Meeting, Salt Lake City, Utah, September 9-11, 1980: Los Alamos Scientific Laboratory LASL-80-36, p. 5-8.

Geotherma1, Geophysics, Tabulated data.

88. Brookins, D. G., 1974, Summary of recent Rb-Sr age determinations from Precambrian rocks of north-central New Mexico, in Guidebook of Ghost Ranch: New Mexico Geological Society, 25th Field Conference, p. 119-121. Geology, Geophysics, Tabulated data.

89. Brookins, D. G., and Laugh1in, A. W., 1976, High 87/86 strontium ratios in seated fracture-filling calcite from GT-2 [abs.]: American Geophysical Union Transactions, v. 57 , no. 4, p. 352-353.

Geology, Geothermal, Geochemistry and geothermometry, Geophysics.

90. 1976, Rubidium-strontium geochronological study of GT-1 and GT-2 hole rocks [abs.]: American Geophysical Union Transactions, v. 57 , no. 4, p. 352 .

Geology, Geothermal, Geochemistry and geothermometry, Geophysics.

91. Brown, D. W., 1973, The potential for hot-dry rock geothermal energy in the Western United States: Los Alamos Scientific Laboratory LA-UR-73-1075, 21 p. Geothermal.

92 . 1976, Recent advances in the deep drilling of hot crystalline rocks [abs.]: American Geophysical Union Transactions, v. 57 , no. 4, p. 349 . Geology, Geothermal, Hydrology. 
93. Brown, D. W., and Potter, R. M., 1973, The LASL geothermal energy program, A summary of in-situ experiments in the first exploratory hole [abs.]: American Geophysical Union Transactions, v. 54, no. 11, p. 1214 .

Geothermal, Geophysics.

94.

1974, Results from hydraulic fracturing experiments in deep crystalline rock [abs.]: American Geophysical

Union Transactions, v. 55, no. 4, p. 425. Geology, Geophysics.

95. Brown, D. W., Smith, M. C., and Potter, R. M., 1973, A new method for extracting energy from 'Dry' geothermal

reservoirs: Los Alamos Scientific Laboratory

LA-DC-72-1157, $22 \mathrm{p}$.

Geotherma1, Geophysics.

96. Brown, L. D., and others, 1980, Deep structure of the Rio Grande Rift from seismic reflection profiling: Journal of Geophysical Research, v. 85, no. B9, p. 4773-4800. Geology, Geophysics.

97. Brown, M. C., and others, compilers, 1979, Hot dry rock geothermal energy development program, Annual report, Fiscal year 1978: Los Alamos Scientific Laboratory LA-7807-HDR, 129 p.

Geotherma1, Geophysics.

98. Brown, W. T., Jr., and Kudo, A. M., 1969, Inclusions of ultramafic and sedimentary rocks in volcanic necks, Sandoval and Valencia Counties, New Mexico [abs.]: Geological Society of America Abstracts with Programs, $1969, \mathrm{p} \cdot 10$.

Geology.

99. Browne11, D. H., Jr., Garg, S. K., and Pritchett, J. W., 1975 , Computer simulation of geothermal reservolrs:

Ventura, California, $45 \mathrm{th}$ Annual Regional Meeting of the Society of Petroleum Engineers, paper SPE5381.

Geothermal, Modeling applications. 
100. Bryan, Kirk, 1938, Geology and ground-water conditions of the Rio Grande depression in Colorado and New Mexico, in Regional Planning, Part 6, Upper Rio Grande: Washington National Resources Commission, p. 197-225.

Geology, Hydrology.

101. Budding, A. J., 1959, Structural geology of the southeast Chama Basin [abs.], in Guidebook of west-central New Mexico: New Mexico Geological Society, 10th Field Conference, p. 160 .

Geology, Tabulated data.

102 . 1978 , Gravity survey of the Pajarito Plateau, Los Alamos and Santa Fe Counties, New Mexico: Los Alamos Scientific Laboratory Informal Report LA-7419-MS, $15 \mathrm{p}$. Geology, Hydrology, Geophysics, Tabulated data.

103. Budding, A. J., and others, 1960, Geology of the southeast part of the Chama Basin, in Guidebook of Rio Chama Country: New Mexico Geological Society, $11 \mathrm{th}$ Field Conference, p. 79-92. Geology.

104 . 1975, Seismicity of Los Alamos area estimated from fault movement [abs.]: New Mexico Academy of Science Bulletin, v. 15, p. 14-15.

Geology, Geophysics.

105. Bufe, C. G., 1983, Geothermal Energy: Geotimes, v. 28, no. 2, p. 22-24. Geothermal.

106. Burkham, D. E., 1967, Hydrology of Cornfield Wash Area and effects of land-treatment practices, Sandoval County, New Mexico, 1951-60: U.S. Geological Survey Water-supply Paper $1831,87 \mathrm{p}$. Geology, Hydrology, Tabulated data. 
107. Bushman, F. X., and Foster, F. W., 1957, Ground-water conditions at Cuba (Sandoval County) independent rural schools' new well site: New Mexico Bureau of Mines and Mineral Resources open-file report.

Geophysics.

108. Cady, G. V., 1969, Model studies of geothermal fluid production: Stanford, Calif., Stanford University, unpublished M.S. thesis, $82 \mathrm{p}$.

Geothermal, Modeling applications, Tabulated data.

109. Callender, J. F., 1975, Overview of the Rio Grande Rift, in Field trips to central New Mexico: American Association of Petroleum Geologists Rocky Mountain Section Meeting, 1975 , part 2, p. 1-4.

Geology, Geophysics.

110. Callender, J. F., and Zilinski, R. E., Jr., 1976, Kinematics of Tertiary and Quaternary deformation along the eastern edge of the Lucero Uplift, central New Mexico, in Tectonics and mineral resources of southwestern North America, 1976: Geological Society Special Publication 6, p. 53-61.

Geology.

111. Callender, J. F., and others, eds., 1978, Guidebook of Land of Cochise (southeastern Arizona): New Mexico Geological Society, $29 \mathrm{th}$ Field Conference, $348 \mathrm{p}$.

Geology, Collected technical articles.

112. Camil1i, Eileen, 1979, Transmission system archaeological analysis, for the proposed Baca geothermal project: consultant report for Union 011 Company of California, Los Angeles, California and Public Service Company of New Mexico, Albuquerque, New Mexico, 98 p.

Geology, Ecology, Tabulated data.

113. Campbe11, J.A., 1967 , Structural geology of part of the Rio Puerco fault belt, west-central New Mexico: Geological Society of America Rocky Mountain Section $12 \mathrm{th}$ Annual Meeting, Program with Abstracts, p. 23.

Geology. 
114. Cantu, J. M., 1979, Visual resource inventory for the proposed Baca geothermal project: Albuquerque, N. Mex., Public Service Company of New Mexico, Environmenta 1 Affairs Department, 35 p. Hydrology, Ecology.

115. Cash, D. J., and others, 1982, Earthquake catalog for northern New Mexico, October - December 1981: Los Alamos Nationa1 Laboratory Progress Report LA-9467-PR, 20 p. Geophysics, Tabulated data.

116. Chapin, C. E., 1971, Asymmetry of the Rio Grande Rift, tectonic implications: Geological Society of America Abstracts with Programs, v. 3, no. 7, p. 765-767. Geology.

117. Chapin, C. E., and Cather, S. M., 1981, Eocene tectonics and sedimentation in the Colorado Plateau, Rocky Mountain Area, in Relations of tectonics to ore deposits in the southern cordillera: Arizona Geological Society Digest, v. $14, \mathrm{p} \cdot 173-198$. Geology.

118. Chapin, C. E., and others, 1978, Exploration framework of the Socorro Geothermal Area, New Mexico, in Field guide to selected cauldrons and mining districts of the Datil-Mogollon Volcanic Field, New Mexico: New Mexico Geological Society Specia1 Publication 7, p. 114-129. Geology, Geothermal.

119. Charles, R. W., 1978, Experimental alteration of a granodiorite in a circulation system, in Geothermal energy, A novelty becomes resource: Geothermal Resources Council, Annual Meeting, 25-27 July, 1978, Hilo, Hawail, v. 2, section 1, p. 87-90.

Geology, Geotherma1, Hydrology. 
120. Charles, R. W., and Herrick, C. C., 1976, Attempts to correlate experimental observations with computer modeling for the prediction of mass transport in some feldspar systems [abs.]: American Geophysical Union Transactions, v. 57 , no. 4. p. 353 .

Geology, Geothermal, Geochemistry and geothermometry, Geophysics, Modeling applications.

121. Chasteen, A. J., 1974, Baca project interim report of test results: Los Angeles, Calif., Union 0il Company of California, Union Geothermal Division, 61 p.

Geothermal, Geochemistry and geothermometry, Hydrology, Geophysics, Tabulated data.

122. Chaturvedi, Lokesh, 1980, Estimation of geothermal potential from geothermal aquifer characteristics and ground water temperature changes with time [abs.]: Internationa 1 Geological Congress Abs.-Congr. Internat. Resumes $26, v \cdot 3$, p. 1096 .

Geothermal, Geochemistry and geothermometry, Hydrology •

123 . 1981 , Geothermal hydrology, in State-coupled low-temperature geothermal resource assessment program, Fiscal Year 1979: New Mexico Energy Research and Development Institute Report EMD 2-66-2211, ch. 8, p. $1-22$.

Geothermal, Hydrology.

124. Chaturvedi, Lokesh, and others, 1979, Use of geothermal energy for desalination in New Mexico - A feasibility study: New Mexico Energy Institute NMEI-42, 136 p. Geology, Geotherma1, Geochemistry and geothermometry, Hydrology, Geophysics, Tabulated data.

125. Cheng, Ping, and Chau, W. C., 1977, Similarity solutions for convection of groundwater adjacent to horizontal impermeable surfaces with axisymmetric temperature distribution: Water Resources Research, v. 13, no. 4, p. 768-772.

Geothermal, Modeling methods and background. 
126. Chenoweth, W. L., 1974, Uranium occurrences of the Nacimiento-Jemez region, Sandoval and Rio Arriba Counties, New Mexico, in Guidebook of Ghost Ranch: New Mexico Geological Society, $25 \mathrm{th}$ Field Conference, p. 309-313. Geology •

127. Christiansen, R. L., and Lipman, P. W., 1972, Cenozoic volcanism and platetectonic evolution of the Western United States. II. Late Cenozoic: Philosophical Transactions of the Royal Society of London, Series A, v. 271, no. 1213, p. 249-284. Geology, Geophysics.

128. Church, F. S., and Hack, J. T., 1939, An exhumed erosion surface in the Jemez Mountains: Journal of Geology, v. 47, no. 6, p. 613-629. Geology.

129. Clark, J. D., 1929, The saline springs of the Rio Salado, Sandoval County, New Mexico: Albuquerque, N. Mex., University of New Mexico Bulletin 163, 29 p. Geology, Geothermal, Geochemistry and geothermometry, Tabulated data.

130. Clark, J. D., and Mauger, Harry, 1932, The chemical characteristics of the waters of the Middle Rio Grande Conservancy District: Albuquerque, N. Mex., University of New Mexico Bulletin, Chemistry Series, v. 2, no. 2, $40 \mathrm{p}$.

Geochemistry and geothermometry, Hydrology, Tabulated data.

131. Clark, J. D., and Priest, K. F., 1932, Public water supplies of New Mexico: Albuquerque, N. Mex., University of New Mexico Bulletin, v. 2, no. 1, 40 p. Geochemistry and geothermometry, Hydrology, Tabulated data.

132. C1iff, W. C., Apley, W. J., and Creer, J. M., 1979, Evaluation of potential geothermal well-head flow sampling and colorimeter methods: Lawrence Berkeley Laboratory LBL-9248, 25 p. Geothermal, Geochemistry and geothermometry, Hydrology. 
133. Co11ie, M. J., 1978, Geotherma1 energy, recent development: Park Ridge, N.J., Noyes Data Corporation, $444 \mathrm{p}$.

Geothermal.

134. Combs, Jim, 1975, Temperatures, geothermal gradients, and heat flow: Bulletin of the Geothermal Resource Council, GTS Technical Memorandum No. $1,3 \mathrm{p}$.

Geotherma1, Hydrology.

135. Conover, C. S., Theis, C. V., and Griggs, R. L., 1963, Geology and hydrology of Valle Grande and Valle Toledo, Sandoval County, New Mexico: U.S. Geological Survey Water-Supply Paper 1619-Y, $37 \mathrm{p}$. Geology, Hydrology, Tabulated data.

136. Controls for Environmental Pollution, Inc., 1974, Baca Ranch geothermal site geothermal radiological monitoring program: consultant report for Union oil Company of California, Union Geothermal Division, Los Angeles, California, 117 p.

Geochemistry and geothermometry, Ecology, Tabulated data.

137. Cook, F. A., 1975, Transient heat-flow models and gravity models in the Rio Grande Rift of southern New Mexico: Laramie, Wyo., University of Wyoming, unpublished M.S. thesis, $114 \mathrm{p}$. Geology, Geotherma1.

138. Coplen, T. B., 1973, Exploration for geothermal systems in the Imperial Valley Area, California, using the $\mathrm{Na}-\mathrm{K}-\mathrm{Ca}$ technique [abs.]: American Geophysical Union Transactions, v. 54, no. 11 , p. 1213 . Geothermal, Geochemistry and geothermometry.

139. Corde11, Lindrith, 1970, Gravity and aeromagnetic investigations of the Rio Grande depression in northern New Mexico [abs.], in Guidebook of Tyrone-Big Hatchet Mountains-Florida Mountains region: New Mexico Geological Society, 21 st Field Conference, p. 158. Geology, Geophysics. 
140 . 1978, Regional geophysical setting of the Rio Grande Rift: Geological Society of America Bulletin, v. 89, p. 1073-1090.

Geophysics.

141 . 1980, Extension of the Rio Grande Rift: Journal of Geophysical Research, v. 87, p. 8561-8569. Geology, Geophysics.

142. Cordel1, Lindrith, and Kottlowski, F. E., 1975, Geology of the Rio Grande Graben: Geology, v. 3, no. 8, p. 420-421. Geology.

143. Cordell, Lindrith, Keller, G. R., and Hildenbrand, T. G., 1982 , Bouguer gravity map of the Rio Grande Rift, Colorado, New Mexico, and Texas: U.S. Geological Survey Map GP-949, scale $1: 1,000,000,1$ sheet [supersedes OF 78-958]. Geology, Geophysics.

144. Core Laboratory, Inc., 1975, Special core analysis study for Union Oil Company of California, Baca No. 13 Well, Redondo Creek Field, Sandoval County, New Mexico: Core analysis for Union Oil Company of California, Union Geothermal Division, Los Angeles, California, 11 p. Geology, Geophysics, Tabulated data.

145. Corwin, R. F., and Hoover, D. B., 1978, The self-potential method in geothermal exploration: Lawrence Berkeley Laboratory LBL-7075, 56 p. Geothermal, Geophysics.

146. Costain, J. K., Glover, Lynn, III, and Sinha, A. K., 1978, Evaluation and targeting of geothermal energy resources in the southeastern United states, Progress report for July 1- September 30, 1978: report by Virginia Polytechnic Institute and State University for U.S. Department of Energy, VPI-SU-5648-4, 141 p. Geothermal, Tabulated data. 
147. Cowan, M. J., compiler, 1946, Geology of the Nacimiento Mountains, San Pedro Mountains, and adjacent plateaus in parts of Sandoval and Rio Arriba Counties, New Mexico: U.S. Geological Survey $0 i 1$ and Gas Investigations Map oM-57, scale 1:95,040, 1 sheet.

Geology.

148. Crow, B. M., and others, 1978, Hot dry rock resource assessment and site selection, in Hot dry rock geothermal energy development project, annual report, fiscal year 1977: Los Alamos Scientific Laboratory Progress Report LA-7109-PR, P. 13-41.

Geology, Geothermal, Hydrology, Tabulated data.

149. Cummings, R. G., 1979, Mining earth's heat, Hot dry rock geothermal energy: Technology Review, MIT Press, v. 81 , no. 4, p. 2-19.

Geothermal, Tabulated data.

150. Cushman, R. L., 1965, An evaluation of aquifer and well characteristics of municipal well fields in Los Alamos and Guaje Canyons, near Los Alamos, New Mexico: U.S. Geological Survey Water-Supply Paper 1809-D, 50 p. Geology, Hydrology, Tabulated data.

151. Cushman, R. L., and Purtymun, W. D., 1975, Evaluation of yield and water-level relations: Los Alamos Scientific Laboratory Informal Report LA-6086-MS, 14 p. Hydrology, Tabulated data.

152. D'Amore, Franco, and Truesdel1, A. H., 1980, Gas geothermometry for drillhole fluids from vapor dominated and hot water geothermal fields, in Proceedings, $6 \mathrm{th}$ Workshop, Geothermal Reservoir Engineering, December 16-18, 1980: Stanford, Calif., Stanford University SPG-TR-50, p. 351-360.

Geothermal, Geochemistry and geothermometry, Tabulated data.

153. Darton, N. H., 1922, Geologic structure of parts of New Mexico, in Contributions to economic geology (short papers and preliminary reports), Part II. Mineral fuels: U.S. Geological Survey Bulletin 726, p. 173-275. Geology 
154.

1922, Geothermal data of the United States,

including many original determinations of underground

temperature: U.S. Geological Survey Bulletin 701, 97 p.

Geology, Geothermal, Hydrology, Tabulated data.

155.

1928, 'Red beds' and associated formations in New

Mexico: U.S. Geological Survey Bulletin 794, 356 p.

Geology, Tabulated data.

156. Daugherty, L. A., and Buchanan, B. A., 1979, Soil inventory for the proposed Baca geothermal project: consultant report for Union Oil Company of California, Union Geothermal Division, Los Angeles, California, and Public Service Company of New Mexico, Albuquerque, New Mexico, $137 \mathrm{p}$.

Hydrology, Tabulated data.

157. Decker, E. R., 1973, Geothermal studies in the southern Rocky Mountain Region 1971-1973 [abs.]: Geologica1 Society of America Abstracts with Programs, v. 5, no. 6, p. 475-476.

Geology, Geothermal, Geophysics.

158. Dellechaie, F. A., 1977, A geological and hydrological geochemical study of the Animas Geothermal Area, Hidalgo County, New Mexico: Geothermal Resources Council Transactions, v. 1, p. 73-76.

Geology, Geothermal, Geochemistry and geothermometry, Hydrology.

159. Dennis, B. R., and Murphy, H. D., 1978, Borehole temperature survey analysis, hot dry rock geothermal reservoir, in Geothermal energy, A novelty becomes resource: Geothermal Resources Council, Annual Meeting, July 25-27, 1978, v. 1, section 1, p. 149-152. Geology, Geothermal.

160. Denny, C. S., 1938, Santa Fe Formation [abs.]: Geological Society of America Bulletin, v. 49, no. 12, p. 1877 . Geology. 
161 1968 , A descriptive catalog of selected aerial photographs of geologic features in the United States : U.S. Geological Survey Professional Paper 590, 120 p. Geology .

162. Denton, R., 1980, Preliminary subsurface geology and structure of the Bandelier Tuff, Redondo Creek Field, New Mexico: Los Angeles, Calif., Union Oil Company of California, Union Geothermal Division, 69 p. Geology, Geothermal, Tabulated data.

163. Dickson, F. W., and Arnston, R. H., 1967, Solubility of magnesite in $\mathrm{CO} 2-\mathrm{H} 20$ at 150,200 , and 250 degrees C., and 100,500 , and 1000 bars [abs.], in Program, Geological Society of America, meeting in New orleans, 1967 : Geological Society of America, p. 48 .

Geothermal, Geochemistry and geothermometry.

164. Dinwiddie, G. A., 1964, Availability of ground water for irrigation on the Pojoaque Pueblo Grant, Santa Fe County, New Mexico: U.S. Geological Survey Open-File Report $64-43,14 \mathrm{p}$.

Geology, Geochemistry and geothermometry, Hydrology, Tabulated data.

165. Dinwiddie, G. A., Mourant, W. A., and Basler, J. A., 1966, Municipal water supplies and uses, northwestern New Mexico: New Mexico State Engineer office Technical Report $29 \mathrm{C}, 197 \mathrm{p}$.

Geochemistry and geothermometry, Hydrology, Tabulated data.

166. Dipippo, R., 1978, Geothermal power plants of the United States, A technical survey of existing and planned installations: Providence, R.I., Brown University Report No. C00-4051-20, 129 p.

Geotherma1.

167. Doe, B. R., 1967, Lead-isotope studies of Cenozoic rocks in the Rocky Mountain region--A summary: Geological Society of America Rocky Mountain Section, 1967 Meeting Paper, p. 32 .

Geology, Geochemistry and geothermometry. 
168 . 1967, The bearing of lead isotopes on the source of granitic magma: Journal of Petrology, v. 8, pt. 1, p. $51-83$. Geology, Geothermal, Geochemistry and geothermometry.

169 . 1968 , Lead and strontium isotopic studies of Cenozoic volcanic rocks in the Rocky Mountain region--A Summary, in Cenozoic volcanism in the southern Rocky Mountains: Colorado School of Mines Quarterly, v. 63, no. 3, p. 149-174. Geology, Geochemistry and geothermometry.

170. Doe, B. R., and others, 1969 , Primitive and contaminated basalts from the southern Rocky Mountains, USA:

Contributions to Mineralogy Petrology, v. 21, p. 142-156. Geology.

171. Doe11, R. R., and others, 1968, Paleomagnetism, potassium-argon ages, and geology of rhyolites and associated rocks of the Valles Caldera, New Mexico, in Studies of Volcanology: Geological Society of America Memoir 116, p. 211-246. Geology, Tabulated data.

172. Domenico, P. A., and Palciauskas, V. V., 1973, Theoretical analysis of forced convective heat transfer in regional ground-water flow: Geological Society of America Bulletin, v. 84, p. 3803-3814.

Modeling methods and background.

173. Donaldson, I. G., 1962, Temperature gradients in the upper layers of the earth's crust due to convective water flows: Journal of Geophysical Research, v. 67, p. 3449 . Geology, Geothermal, Geophysics.

174. 1968, The flow of steam-water mixtures through permeable beds, a simple simulation of a natural undisturbed hydrothermal region: New Zealand Journal of Science, v. 11 , no. 1, p. 3 . Geothermal, Modeling methods and background, Modeling applications. 
175 .

1971, The simulation of geothermal systems with a simple convective model, in Proceedings of the United Nations symposium on the development and utilization of geothermal resources, Pisa (Italy), September 22 october 1, 1970: Geothermics International Journa1 of Geotherma1 Research, Special Issue 2, part 1, p. 649-654. Geothermal, Modeling methods and background, Modeling applications, Review articles, Collected technical articles.

176. Dondanville, R. F., 1971, Hydrothermal geology of the Valles Caldera, New Mexico: Los Angeles, Calif., Union 0il Company of California, Union Geothermal Division, 36 p., 4 appendices.

Geology, Geothermal, Hydrology, Tabulated data.

177 . 1978, Geologic characteristics of the Valles Caldera Geothermal System, New Mexico: Geothermal Resources Council Transactions, v. 2, p 157-159. Geology, Geothermal.

178. Duchene, H. R., 1974, Pennsylvanian rocks of north-central New Mexico, in Guidebook of Ghost Ranch: New Mexico Geological Society, 25th Field Conference, p. 159-165. Geology.

179 . 1974, Structure of the Guadalupe Box Area, Sandoval County, New Mexico, in Guidebook of Ghost Ranch: New Mexico Geological Society, $25 \mathrm{th}$ Field Conference, p. 131-135. Geology

180. Dunigan Enterprises, Inc., 1971, Summary sheets for Baca Wells number 1 to 3: Abilene, Tex., Dunigan Enterprises, Inc., Baca Land and Cattle Company, 6 p. Geology, Geothermal, Hydrology, Tabulated data.

181. Duschatko, R. W., 1953, Fracture studies in the Lucero Uplift, New Mexico - Final report: New York, N.Y., Columbia University, U.S. Atomic Energy Commission RME-3072, $49 \mathrm{p}$.

Geology. 
182. Eaton, G. P., and others, 1972, Comparative geophysical expression of ash flow-related calderas, Southwestern United States [abs.]: Geological Society of America Abstracts with Programs, v. 4, no. 7, p. 496. Geology, Geophysics.

183. Eddy, Andrea, Laughlin, A. W., and Hershman, A., 1978, Core studies applied to hot dry rock geothermal energy extraction: Abstracts of Papers of the $144 \mathrm{th}$ National Meeting of the Association for the Advancement of Science, February 1978 , p. 178 . Geology, Geothermal, Geophysics.

184. Edwards, C. L., and others, 1978, Terrestrial heat flow and crustal radioactivity in northeastern New Mexico and southeastern Colorado: Geological Society of America Bulletin, v. 89, no. 9, p. 1341-1350. Geology, Geotherma1, Geophysics.

185. Eichelberger, J. C., and Westrich, H. R., 1980, Geology of the Rio Grande Rift, in Continental scientific drilling program thermal regimes - Comparative site assessment geology of five magma-hydrothermal systems: Los Alamos Scientific Laboratory Conference Proceedings LA-8550-OBES, p. 37-50.

Geology, Geothermal, Geochemistry and geothermometry, Hydrology, Geophysics.

186. Elder, J. W., 1981, Geothermal systems: New York, N.Y., Academic Press, 508 p.

Geology, Geothermal, Geochemistry and geothermometry, Hydrology, Geophysics, Modeling methods and background, Modeling applications, Modeling evaluation and documentation, Textbook, Tabulated data.

187. E11is, A. J., 1975, Geothermal systems and power development: American Scientist, v. 16, p. 510-521. Geothermal, Modeling applications, Review articles. 
188. E1sner, D. B., 1978, Proceedings of hot dry rock geotherma1 workshop, Los Alamos, New Mexico, Apri1 20-21, 1978: Los Alamos Scientific Laboratory LA-7470-C, 63 p.

Geotherma1, Geochemistry and geothermometry, Hydrology, Geophysics, Collected technical articles.

189. E1ston, W. E., 1961, Minera1 resources of Berna1i11o, Sandoval and Santa Fe Counties, New Mexico (exclusive of oil and gas), in Guidebook of Albuquerque Country: New Mexico Geological Society, 12 th Field Conference, p. $155-167$.

Geology.

190 . 1970 , Determination of flow direction of rhyolite ash-flow tuffs from fluidal textures: Geological Society of America Bulletin, v. 81, no. 11, p. 3393-3406. Geology, Geophysics.

191 . 1974, Structura1 control of the pre-20 million year volcanic centers, clue to early evolution of the Rio Grande Trough, in Guidebook of Tyrone-Big Hatchet Mountains-F1orida Mountains region: New Mexico Geological Sóciety, 21st Field Conference, p. 157-158. Geology, Geophysics.

192 . 1974, Volcano-tectonic control of ore deposits, southwestern New Mexico, in Guidebook of Tyrone-Big Hatchet Mountains-F1orida Mountains region: New Mexico Geologica 1 Society, 21 st Field Conference, p. 147-153. Geology.

193. Fagadau, S. P., 1954, Geology of the Rio Grande Depression in New Mexico [abs.]: American Association of Petroleum Geologists Bulletin, v. 38, no. 5, p. 944-945. Geology. 
194. Faust, C. R., and Mercer, James W., 1975, Mathematica1 modeling of geothermal systems, in Proceedings, Second United Nations symposium on the development and use of geothermal resources, San Francisco, California, USA, May 20-29, 1975: U.S. Government Printing office, v. 3, p. $1635-1641$.

Geothermal, Hydrology, Modeling methods and background, Modeling applications, Tabulated data.

195. 1979, Geothermal reservoir simulation, 1.

Mathematical models for liquid-and vapor-dominated hydrothermal systems: Water Resources Research, v. 15 , no. 1, p. 23-30. Geothermal, Modeling methods and background.

196. 1979, Geothermal reservoir simulation, 2. Numerical solution techniques for liquid-and vapor-dominated hydrothermal systems: Water Resources Research, v. 15 , no. $1, p \cdot 31-46$.

Geothermal, Modeling methods and background.

197. Faust, C. R., Mercer, James W., and Miller, W. J., 1980, Geothermal reservoir engineering computer code comparison and validation (Final report): U.S. Department of Energy DE-80F11452, $56 \mathrm{p}$. (Errata in second volume). Geothermal, Modeling evaluation and documentation.

198. Faust, C. R., Mercer, James W., and Thomas, S. D., 1983, Final report, Quantitative analysis of geothermal development in the Jemez Mountains: U.S. Bureau of Indian Affairs, $85 \mathrm{p}$. and 5 appendices.

Geothermal, Hydrology, Tabulated data.

199. Fischer, E. E., and Borland, J. P., 1983, Estimation of natural streamflow in the Jemez River at the boundaries of Indian lands, central New Mexico: U.S. Geological Survey Water-Resources Investigations 82-4113, 27 p. Hydrology, Tabulated data. 
200. Flavil, P., and Whitford, W. G., 1978, The biota of Redondo Creek, Union Geothermal Exploration Site, Sandoval County, New Mexico: Las Cruces, N. Mex., Whitford Ecological Consultants, 63 p.

Ecology.

201. Flesch, G. A., 1974, Stratigraphy and sedimentology of the Morrison Formation (Jurassic), ojito Spring Quadrangle, Sandoval County, New Mexico, a preliminary discussion, in Guidebook of Ghost Ranch: New Mexico Geological Society, 25th Field Conference, p. 185-195. Geology •

202. F1esch, G. A., and Wilson, M. D., 1974, Petrography of Morrison Formation (Jurassic) Sandstone of the ojito Spring Quadrangle, Sandoval County, New Mexico, in Guidebook of Ghost Ranch: New Mexico Geological Society, 25th Field Conference, p. 197-210. Geology.

203. Foote, H. P., Wukelic, G. E., and Blair, S. C., 1982, Digital techniques for the integration and display of multisource data: Richland, Wash., Pacific Northwest Laboratory, $10 \mathrm{p}$. Geology, Hydrology, Geophysics.

204. Fournier, R. 0., 1977, Chemical geothermometers and mixing models for geothermal systems: Geothermics, v. 5, p. $41-50$. Geotherma1, Geochemistry and geothermometry.

205 . 1980 , Application of water geochemistry to geothermal exploration and reservoir engineering, in Geothermal systems, principles and case histories: New York, John Wiley, p. 109-143.

Geotherma1, Geochemistry and geothermometry, Tabulated data.

206. Fournier, R. 0., and Potter, R. W., II, 1979, Magnesium correction to the $\mathrm{Na}-\mathrm{K}-\mathrm{Ca}$ chemical geothermometer: Geochimica et Cosmochimica Acta [Peragmon Press, Great Britain], v. 43, p. 1543-1550.

Geothermal, Geochemistry and geothermometry, Tabulated data. 
207. Fournier, R. O., and Rowe, J. J., 1966, Estimation of underground temperatures from the silica content of water from hot springs and wet-steam wells: American Journal of Science, v. 264, p. 685-697. Geothermal, Geochemistry and geothermometry, Tabulated data.

208. Fournier, R. 0., and Truesdel1, A. H., 1970, Chemical indicators of subsurface temperature applied to hot spring waters of Yellowstone National Park, Wyoming, USA, in Proceedings, Second United Nations symposium on the development and utilization of geothermal resources, Pisa (Italy), September 22 - october 1, 1970: Geothermics International Journal of Geothermal Research, Special Issue 2, part 1 , p. 529-535.

Geothermal, Geochemistry and geothermometry, Tabulated data.

209 . 1973, An empirical $\mathrm{Na}-\mathrm{K}-\mathrm{Ca}$ geothermometer for natural waters: Geochimica et Cosmochimica Acta [Pergamon Press, Great Britain], v. 37, p. 1255-1275.

Geothermal, Geochemistry and geothermometry.

210

1974, Geochemical indicators of subsurface

temperature, part 2, Estimation of temperature and fraction of hot water mixed with cold water: Journal of Geophysical Research, v. 2, no. 3, p. 263-270. Geothermal, Geochemistry and geothermometry, Tabulated data.

211. Fournier, R. 0., White, D. E., and Truesde11, A. H., 1974 , Geochemical indicators of subsurface temperature, part 1 , Basic assumptions: U.S. Geological Survey Journal of Research, v. 2, no. 3, p. 259-262.

Geothermal, Geochemistry and geothermometry.

212. Fournier, R. O., and others, 1979, Chemical and isotopic prediction of aquifer temperatures in the geothermal system at Long Valley, California: Journal of Volcanology and Geothermal Research, v. 5, p. 17-34.

Geothermal, Geochemistry and geothermometry, Tabulated data. 
213. Friewald, D. A., 1978, Hot dry rock geothermal energy, the potential for the United States: Los Alamos Scientific Laboratory Mini-review LASL-78-24, 4 p. Geothermal, Geophysics, Tabulated data.

214. Fritz, Peter, and Fontes, J. C., eds., 1980, Handbook of environmental isotope geochemistry, Volume 1 , The terrestrial environment, A.: New York, N.Y., Elsevier Scientific Publishing Company, $545 \mathrm{p}$. Geothermal, Ecology, Geophysics, Tabulated data.

215. Fuchs, R. L., and Huttrer, G. W., 1975, Geothermal energy, Slow-growing industry finally heats up: Engineering Mining Journa1, v. 176, no. 1, p. 89-93. Geothermal.

216 . 1975 , Geothermal energy, The challenges that lie ahead: Engineering Mining Journal, v. 176, no. 2, p. $78-82$. Geotherma1.

217. Galusha, Ted, and Blick, J. C., 1971, Stratigraphy of the Santa Fe Group, New Mexico: American Museum of Natural History Bulletin, v. 144, article 1, 127 p. Geology.

218. Gamble, T. D., Goubeau, W. M., and Clarke, J., 1979, Error analysis for remote reference magnetotellurics:

Geophysics, v. 44, p. 959-968.

Geophysics.

219 . 1979, Magnetotellurics with remote reference: Geophysics, v. 44, p. 53-68. Geophysics. 
220. Garg, S. K., and Pritchett, J. W., 1980, Pressure transient analysis for hot water and two-phase wells, Some numerical results: Systems, Science and Software SSS-R-81-4708 consultant report for Union Geothermal Company of New Mexico (see Union Oil Company of California, Union Geothermal Division, Los Angeles, California), Public Service Company of New Mexico, Albuquerque, New Mexico, and U.S. Department of Energy, $60 \mathrm{p}$. Geothermal, Tabulated data.

221. Garg, S. K., Pritchett, J. W., and Brownel1, D. H., Jr., 1975, Transport of mass and energy in porous media, in Proceedings, Second United Nations symposium on the development and use of geothermal resources, San Francisco, California, USA, May 20-29, 1975: U.S. Government Printing Office, v. 3, p. 1651-1656.

Geophysics.

222. Gentry, R. V., and others, 1976, Dwarf radiohalos [abs.]: American Geophysical Union Transactions, v. 57, no. 4, p. 352 .

Geology, Geochemistry and geothermometry, Geophysics.

223. Geonomics Inc., 1976, Magnetotelluric-telluric profile survey of the Valles Caldera prospect, Sandoval County, New Mexico: consultant report for Union 0il Company of New Mexico, Union Geothermal Division, Los Angeles, California, $133 \mathrm{p}$.

Geology, Geothermal, Geophysics, Tabulated data.

224 .

1978, Geothermal environmental impact assessment, Baseline data for four geothermal areas in the United States, interagency energy-environment research and development program report: U.S. Environmental Protection Agency EPA-600/7-78-188, 339 p. and plates. Geology, Geothermal, Hydrology, Ecology, Geophysics, Tabulated data. 
225 . 1978, Geothermal environmental impact assessment, Sub-surface environmental assessment for four geothermal systems, interagency energy-environment research and development program report: U.S. Environmental Protection Agency EPA-600/7-78-207, 239 p. Geology, Geothermal, Hydrology, Ecology, Tabulated data.

226. Geothermal Resources Council, 1978, Geothermal energy, A novelty becomes resource: Geothermal Resources Council, Annual Meeting, Hilo, Hawaii, 25-27 July, 1978, v. 2,2 sections, 748 p.

Geology, Geothermal, Geochemistry and geothermometry, Ecology, Geophysics, Collected technical articles.

227. Geothermics, 1970, Proceedings of the United Nations symposium on the development and utilization of geothermal resources, Pisa (Italy), September 22-0ctober 1, 1970: Geothermics Internationa1 Journal of Geotherma1 Research, Special Issue 2, 2 parts, 1725 .

Geology, Geothermal, Geochemistry and geothermometry, Bibliography, Collected technical articles, Tabulated data.

228. Geotrans, Inc., 1980, Corrections to report 10-00K, Geothermal reservoir engineering computer code comparison and validation: consultant report for U.S. Department of Energy, 10 p.

Modeling evaluation and documentation.

229 .

1981 , Interim report - Status of modeling activities for Baca Location, New Mexico: Reston, Va., Geotrans, Inc., $49 \mathrm{p}$. Modeling applications, Modeling evaluation and documentation.

230. G1adney, E. S., and others, 1982, Quality assurance for environmental analytical chemistry, 1981: Los Alamos National Laboratory Informal Report LA-9579-MS, 128 p. Geochemistry and geothermometry, Hydrology, Ecology, Tabulated data. 
231. Goff, F. E., 1983, Subsurface structure of Val1es Caldera,

A resurgent cauldron in northern New Mexico [abs.]:

Geological Society of America Abstracts with Programs,

v. 15 , no. 5, p. 381 .

Geology.

232. Goff, F. E., and Bolivar, S. L., 1982, Valles Caldera field trip guidebook, October 5-7, 1982: Los Alamos National

Laboratory Earth and Space Sciences Division, 23 p.

Geology, Geothermal, Geochemistry and geothermometry, Hydrology, Geophysics.

233 .

1983, Field trip guide to the Valles Caldera and its geothermal systems: Los Alamos National Laboratory LA-9963-OBES, $53 \mathrm{p} ., 1 \mathrm{map}$.

Geology, Geothermal, Geochemistry and geothermometry, Hydrology.

234. Goff, F. E., and Donne11y, J. M., 1978, The influence of PC02, salinity, and bedrock type of the Na-K-Ca geothermometer as applied in the C1ear Lake geothermal region, California: Transactions of the Geothermal Resources Council, v. 2, p. 211-214.

Geology, Geothermal, Geochemistry and geothermometry, Hydrology, Geophysics.

235. Goff, F. E., and Gardner, J. N., 1980, Geologic map of the Sulphur Springs area, Valles Caldera geothermal system, New Mexico: Los Alamos National Laboratory LA-8634-MAP, scale $1: 5000,2$ sheets. Geology, Geothermal.

236. Goff, F. E., and Grigsby, D. O., 1982, Valles Caldera Geothermal Systems, New Mexico, USA: Journal of Hydrology, v. 56, no. 1/2, p. 119-136.

Geology, Geothermal, Geochemistry and geothermometry, Hydrology, Tabulated data.

237. Goff, F. E., and Kron, Andrea, 1980, In-progress geologic map of Canyon de San Diego, Jemez Springs, New Mexico, and lithologic 1 og of Jemez Springs geothermal we11: Los Alamos National Laboratory LA-8276-MAP, scale 1:12,000, 1 sheet.

Geology, Geothermal, Hydrology. 
238. Goff, F. E., and Sayer, Suzanne, 1980, A geothermal investigation of spring and well waters of the Los Alamos region, New Mexico: Los Alamos National Laboratory Informal Report LA-8326-MS, 21 p.

Geotherma1, Geochemistry and geothermometry, Hydrology, Tabulated data.

239. Goff, F. E., and Waters, A. C., eds., 1980, Continental scientific drilling program thermal regimes - Comparative site assessment geology of five magma-hydrothermal systems: Los Alamos Scientific Laboratory LA-8550-OBES, $100 \mathrm{p}$.

Geology, Geothermal, Geochemistry and geothermometry, Hydrology, Geophysics, Collected technical articles, Tabulated data.

240. Goff, F. E., Maxwe11, J. C., and Stewart, B. S., 1978 , Preliminary plane table map, Soda Dam, Jemez Springs, New Mexico: Los Alamos National Laboratory LA-7520-MAP, scale $1: 300,1$ sheet.

Geology, Geothermal, Hydrology.

241. Goff, F. E., and others, 1981, Geology, water geochemistry and geothermal potential of the Jemez Springs Area, Cañon de San Diego, New Mexico: Journal of Volcanology and Geotherma1 Research, v. 10, p. 227-244.

Geology, Geothermal, Geochemistry and geothermometry, Hydrology.

242 .

1982 , Geochemical data for 95 thermal and

non-thermal waters of the Valles Caldera, southern Jemez Mountains region, New Mexico: Los Alamos National

Laboratory LA-9367-OBES, 51 p

Geology, Geotherma1, Geochemistry and geothermometry, Hydrology, Tabulated data.

243 .

1983, Water geochemistry of the Lucero Uplift, New

Mexico. A geothermal investigation of low-temperature mineralized fluids: Los Alamos National Laboratory LA-9738-OBES, 26 p.

Geology, Geothermal, Geochemistry and geothermometry, Hydrology, Tabulated data. 
244. Golabi, Kama1, and others, 1981, Optimal energy extraction from a hot water geothermal reservoir: Water Resources Research, v. 17, no. 1, p. 1-10. Geothermal, Modeling applications.

245. Goldstein, N. E., Holman, W. R., and Molloy, M. W., eds., 1982 , Final report of the Department of Energy reservoir definition review team for the Baca geothermal demonstration project: Lawrence Berkeley Laboratory LBL-14132, 51 p.

Geology, Geotherma1, Geochemistry and geothermometry, Hydrology, Geophysics, Collected technical articles, Tabulated data.

246. Gottfried, David, 1958, Uranium in some volcanic rocks: U.S. Geological Survey Trace Elements Investigations Report 750, p. 95-101.

Geology.

247. Gould, T. L., 1973, Vertical two-phase steam-water flow in geothermal we11s: American Geophysical Union

Transactions, v. 54, no. 11 , p. 1215 .

Geothermal, Geochemistry and geothermometry, Hydrology, Geophysics.

248. Goya 1, K. P., Miller, D. W., and Lippmann, M. J., 1980 , Effect of measured wellhead parameters and well scaling on the computed downhole conditions in Cerro prieto wells, in Proceedings, $6 \mathrm{th}$ Workshop, Geothermal Reservoir Engineering, December 16-18, 1980: Stanford, Calif., Stanford Universtiy SPG-TR-50, p . 130-138. Geothermal.

249. Granger, H. C., 1956, Radioactive spring deposits, Perry Robb property, Jemez Springs, in Radioactive deposits in New Mexico: U.S. Geological Survey Bulletin 1009-L, p. L 358-L 361. Geology, Geothermal, Hydrology. 
250. Grant, Keith, and Owen, D. E., 1974, The Dakota Sandstone (Cretaceous) of the southern part of the Chama Basin, New. Mexico--A preliminary report on its stratigraphy, paleontology, and sedimentology, in Guidebook of Ghost Ranch: New Mexico Geological Society, $25 \mathrm{th}$ Field Conference, p. 239-249. Geology.

251. Grant, M. A., 1979, Interpretation of downhole measurements at Baca, in Proceedings, Fifth Workshop, Geothermal Reservoir Engineering, December 12-14, 1979: Stanford, Calif., Stanford University SGP-TR-40, 7 p. Geology, Geothermal, Hydrology, Geophysics.

252 . 1979, Interpretation of downhole measurements in geothermal wells: Wellington, New Zealand, Department of Scientific and Industrial Research, Report No. 88, 66 p. Geology, Geothermal, Hydrology, Geophysics.

253. Grant, M. A., and Garg, S. K., 1981, Interpretation of downhole data from the Baca geothermal field, status as of June 1981: Geothermal Resources Council Transactions, v. 5, p. 337-340. Geology, Geothermal, Geophysics.

254. Grant, M. A., and Sorey, M. L., 1979, The compressibility and hydraulic diffusivity of a water-steam flow: Water Resources Research, v. 15, no. 3, p. 684-686.

Geothermal, Hydrology, Geophysics, Tabulated data.

255. Griggs, R. L., 1956, Geology of the Los Alamos area, New Mexico [abs.]: Geological Society of America Bulletin, v. 67 , no. 12, p. 1794 .

Geology.

256 . 1964, Geology and ground-water resources of the Los Alamos area, New Mexico, with a section on quality of water by J. D. Hem: U.S. Geological Survey Water-Supply Paper $1753,107 \mathrm{p}$.

Geology, Hydrology, Tabulated data. 
257. Group Seven, Inc., 1972, Additiona1 electrical geophysical survey in the Valles Caldera area, Sandoval County, New Mexico: consultant report for Union 0il Company of California, Union Geothermal Division, Los Angeles, Calif., $112 \mathrm{p}$.

Geotherma1, Hydrology, Geophysics, Tabulated data.

258 .

1972, Electrical resistivity survey in Valles

Ca1dera, New Mexico: consultant report for Union 0il

Company of California, Union Geothermal Division, Los Angeles, California, $118 \mathrm{p}$.

Geotherma1, Hydrology, Geophysics, Tabulated data.

259. Gulati, M. R., 1975, Baca reservoir studies: Los Angeles, Calif., Union $0 i 1$ Company of California, Union Geotherma 1 Division, 7 appendices.

Geotherma1, Hydrology, Geophysics, Tabulated data.

260. Gutschick, Vincent, and Rea, K. H., 1978, Environmental assessment of dissolved gases in LASL's hot dry rock geothermal source demonstration project, in Geothermal energy, A novelty becomes resource: Geothermal Resources Council, Annual Meeting, 25-27 July, 1978, Hilo, Hawaii, v. 2, section 1, p. 249-252.

Geochemistry and geothermometry, Ecology.

261. Haas, J. L., Jr., 1971, The effect of salinity on the maximum thermal gradient of a hydrothermal system at hydrostatic pressure: Economic Geology, v. 66, p. 940-946.

Geology, Geotherma1, Geochemistry and geothermometry.

262. Hale, W. E., Reiland, L. J., and Beverage, J. P., 1965 , Characteristics of water supply in New Mexico: New Mexico State Engineer office Technical Report 31, 131 p.

Hydrology, Tabulated data.

263. Hamilton, Warren, and Myers, W. B., 1966, Cenozoic tectonics of the western United States: Reviews of Geophysics, v. 4, no. 4, p. 509-549.

Geology, Geophysics. 
264. Hammond, A. L., 1973, Dry geothermal wells, Promising experimental results: Science, v. 182, no.4107, p.43-44. Geothermal.

265. Hardee, H. C., and Larson, D. W., 1977, The extraction of heat from magmas based on heat transfer mechanisms:

Journal of Volcanology and Geothermal Research, v. 2, p. 113-144.

Geology, Geothermal, Hydrology

266. Harder, Vicki, Morgan, Pau1, and Swanberg, C. A., 1980 ,

Geothermal resources in the Rio Grande rift - Origins and potential: Geothermal Resources Council Transactions, v. 4, p. 61-64.

Geology, Geothermal.

267. Hare, R. F., and Mitche11, S. R., 1912, Composition of some New Mexico waters: Las Cruces, N. Mex., New Mexico State University, Agricultural Experiment Station Bulletin 83 , $76 \mathrm{p}$. Geochemistry and geothermometry, Hydrology, Tabulated data.

268. Harlow, F. H., and Pracht, W. E., 1972, A theoretical study of geothermal energy extraction: Journal of Geophysical Research, v. 77, no. 35, p. 7038-7048. Geology, Geotherma1, Hydrology, Geophysics, Tabulated data.

269. Harrington, E. R., 1943, Geology of the high country: New Mexico Magazine, v. 19, no. 1, p. 24-25, 39-40. Geology.

270 . 1943, Springs of the Jemez plateau: New Mexico Magazine, v. 21, no. 1, p. 7-9. Geothermal, Hydrology. 
271. Hartz, J. D., 1976, Geotherma1 reservoir evaluation of the Redondo Creek area, Sandoval County, New Mexico:

Los Angeles, Calif., Union Oil Company of California, Union Geothermal Division, 87 p., 8 appendices.

Geology, Geothermal, Geochemistry and geothermometry, Hydrology, Tabulated data.

272 .

1977 , Baca We11 No. 15 production test and reservoir evaluation: Los Angeles, Calif., Union 0il Company of California, Union Geothermal Division, 32 p., figures and 2 appendices.

Geotherma1, Geochemistry and geothermometry, Hydrology, Geophysics, Tabulated data.

273.

1977 , Baca We11 No. 5A, Pressure falloff and

injection: Los Angeles, Calif., Union Oil Company of

California, Union Geothermal Division, 7 p.

Geothermal, Geochemistry and geothermometry, Hydrology, Tabulated data.

274 .

1977, Effects of turbine power cycle on development

we11 requirements in Redondo Creek: Los Angeles, Calif., Union 0il Company of California, Union Geothermal

Division, 25 p.

Geotherma1, Hydrology, Tabulated data.

275. Harvey, D. J., 1979, LASL manages the national program, in Expanding the Hot Dry Rock Program: Los Alamos Scientific Laboratory LASL-79-60, p. 8-11.

Geothermal, Tabulated data.

276. Hatton, K. S., 1978, Geothermal energy, in New Mexico's energy resources $177,--0 f f i c e$ of the state Geologist: New Mexico Bureau of Mines and Mineral Resources Circular 167 , p. $42-47$.

Geotherma1.

277 . 1980, Geothermal energy, in New Mexico's energy resources $179,--A n n u a l$ report of Bureau of Geology in the Mining and Minerals Division of New Mexico Energy and Minerals Department: New Mexico Bureau of Mines and Mineral Resources Circular 172, p. 49-53. Geothermal. 
278 1981, Geothermal energy, in New Mexico's energy resources ' $80,--$ Annual report of Bureau of Geology in the Mining and Minerals Division of New Mexico Energy and Minerals Department: New Mexico Bureau of Mines and Minera1 Resources Circular 181, p. 50-57. Geothermal, Tabulated data.

279 . 1982, Geothermal energy, in New Mexico's energy resources 181: --Annual report of Bureau of Geology in the Mining and Minerals Division of New Mexico Energy and Minerals Department: New Mexico Bureau of Mines and Mineral Resources Annual Report, p. 52-59. Geotherma1, Tabulated data.

280. Hawley, J. W., compiler, 1978, Guidebook to the Rio Grande Rift in New Mexico and Colorado: New Mexico Bureau of Mines and Mineral Resources Circular 163, 241 p. Geophysics, Review articles, Collected technical articles.

281. Healy, F. G., 1927, Log and drilling records of water wells at Cuba and La Jara, New Mexico: New Mexico State Engineer office open-file report, $6 \mathrm{p}$.

Geology, Hydrology, Geophysics.

282. Hearne, G. A., 1985, Mathematical model of the Tesuque aquifer system near Pojoaque, New Mexico: U.S. Geological Survey Water-Supply Paper 2205,75 p.

Hydrology, Modeling applications, Tabulated data.

283 .

1985, Simulation of an aquifer test on the Tesuque Pueblo Grant, New Mexico: U.S. Geological Survey Water-Supp1y Paper 2206, 24 p.

Hydrology, Modeling methods and background, Modeling applications, Modeling evaluation and documentation, Tabulated data.

284. Heiken, Grant, and Goff, F. E., 1983, Hot dry rock geothermal energy in the Jemez Volcanic Field, New Mexico: Journal of Volcanology and Geothermal Research, v. 15, p. 223-246.

Geology, Geothermal. 
285. Helmick, Catherine, 1981, Rio Grande Rift, A window into the earth: Los Alamos Scientific Laboratory Mini-review LAL $-81-18,4 \mathrm{p}$. Geology.

286. Hemley, J. J., 1967, Aqueous solutions and hydrothermal activity: American Geophysical Union Transactions, v. 48 , no. 2, p. 647-653.

Geotherma1, Geochemistry and geothermometry, Hydrology, Bibliography, Review articles.

287. Henbest, L. G., and Read, C. B., 1944, Stratigraphic distribution of the Pennsylvanian Fusulinidae in part of the Sierra Nacimiento of Sandoval and Rio Arriba Counties, New Mexico: U.S. Geological Survey 0il and Gas Investigations Chart oc-2, scale $1: 1,000,000,1$ sheet. Geology.

288. Henderson, Janius, 1913, Geology and topography of the Rio Grande region in New Mexico: Bureau of American Ethnology Bulletin 54, p. 23-39. Geology.

289. Herceg, J. E., 1972, Environmental monitoring in the vicinity of the Los Alamos Scientific Laboratory, July through December 1971: Los Alamos Scientific Laboratory LA-4970, $46 \mathrm{p}$. Hydrology, Ecology, Tabulated data.

290 . 1973 , Environmental monitoring in the vicinity of the Los Alamos Scientific Laboratory, calender year 1972: Los Alamos Scientific Laboratory LA-5184, 54 p. Geology, Geothermal, Geochemistry and geothermometry, Hydrology, Ecology, Tabulated data.

291. Hermance, J. F., 1979, Toward assessing the geotherma1 potential of the Jemez Mountains volcanic complex, A telluric-magnetotelluric survey: Los Alamos Scientific Laboratory LA-79-36375, 86 p.

Geology, Geothermal, Geophysics. 
292. Hicks, J. D., 1970, Optimization for planning and location of precipitation stations in the Jemez Mountains: Las Cruces, N. Mex., New Mexico State University, unpub1ished M.S. thesis, $176 \mathrm{p}$. Hydrology.

293. Hightower, M. M., 1977, Geothermal desalination potential in New Mexico: Las Cruces, N. Mex., New Mexico State University, unpublished M.S. thesis, $86 \mathrm{p}$. Geothermal.

294. Hill, J. H., 1978, The LASL hot dry rock geothermal energy development project, in Geothermal energy, A novelty becomes resource: Geothermal Resources Council, Annual Meeting, Ju1y 25-27, 1978, Hilo, Hawail, v. 2, section 1, p. 275-277. Geothermal.

295. Hiss, W. L., Trainer, F. W., Black, B. A., and Posson, D. R., 1975, Chemical quality of ground water in the northern part of the Albuquerque-Belen Basin, Bernalillo and Sandoval Counties, New Mexico, in Guidebook of Las Cruces Country: New Mexico Geological Society, 26 th Field Conference, p. 219-235. Geology, Geochemistry and geothermometry, Hydrology, Tabulated data.

296. Holland, H. D., 1959, Some applications of thermochemical data to problems of ore deposits. I. Stability relations among the oxides, sulfides, sulfates and carbonates of ore and gangue metals: Economic Geology, v. 54, p. 184-233. Geology, Geothermal, Geochemistry and geothermometry, Tabulated data.

297. Horne, R. N., and others, 1980, Geothermal reservoir engineering computer code comparison and validation using the Genoz simulator program (Final report): U.S. Department of Energy DE-AC03-805F11451, 53 p. Modeling evaluation and documentation. 
298. Howard W. Henry and Company, 1979, Public hearing on the environmental impact statement, geothermal demonstration project, August 30,1979 , transcript of proceedings : prepared by Howard $W$. Henry and Company, Albuquerque, N. Mex., for U.S. Department of Energy, 288 p. Ecology.

299.

1980 , Public hearing on the application of Marcel and Thomas Abousleman for an alternative point and new place and purpose of use from surface water to geothermal water and to appropriate the underground waters of the State of New Mexico: Albuquerque, N. Mex., Howard W. Henry and Company, nos. 02541-B RG-32624,634 p. Geology, Geothermal, Hydrology.

300. Hulen, J. B., and Nielson, D. L., 1982, Stratigraphic permeability in the Baca geothermal system, Redondo Creek area, Valles Caldera, New Mexico: Transactions, Geothermal Resources Council, v. 6, p. 27-30.

Geology, Geothermal.

301. Huyakorn, P. S., and Gelhar, L. W., 1981, Development and application of a computer model for simulating a geothermal system in New Mexico; Final report to the New Mexico Bureau of Mines and Mineral Resources: New Mexico Energy and Minerals Department EMD-2-66-2314,75 p. Modeling methods and background.

302. Icerman, Larry, 1982, A bibliography for low-temperature geothermal resource assessment in New Mexico: New Mexico Energy Research and Development Institute, 48 p.

Geotherma1, Bibliography, Tabulated data.

303. Ingersol1, R. V., ed., 1979, Guidebook of Santa Fe Country: New Mexico Geological Society, 30 th Field Conference, $310 \mathrm{p}$.

Geology, Collected technical articles.

304. Jaffe, F. C., 1971, Geothermal energy, A review: Bulletin Vereinigun Schweiz. Petroleum-Geoligen und Ingenieure de L'association Suisse des Geologues et Ingenieurs du Petrole, v. 38, no. 93, p. 17-40.

Geothermal, Review articles. 
305. James, Russe11, 1980, Significance of the maximum discharge-pressure of geothermal wells, in Proceedings, $6 \mathrm{th}$ Workshop, Geothermal Reservoir Engineering, December 16-18, 1980: Stanford, Calif., Stanford University SPG-TR-50, P. 145-149.

Geothermal, Geophysics, Tabulated data.

306. Jensen, M. L., 1959, Sulfur isotopes and hydrothermal mineral deposits (Santa Rita Mine): Economic Geology, v. 54, no. 3, p. 374-394.

Geology, Geothermal, Geochemistry and geothermometry, Hydrology.

307 .

1958, Sulfur isotopes and the origin of

sandstone-type uranium deposits: Economic Geology, v. 53, no. 5, p. 598-616.

Geology, Geothermal, Geochemistry and geothermometry, Tabulated data.

308. Jiracek, G. R., 1974, Geophysical studies in the Jemez Mountains region, New Mexico, in Guidebook of Ghost Ranch: New Mexico Geological Society, 25 th Field Conference, p. 137-144. Geology, Geophysics.

309 . 1975 , Deep electrical resistivity investigations coupled with geothermal reservoir experiments in New Mexico: National Science Foundation Technical Progress Report, 47 p.

Geology, Geothermal, Geophysics, Tabulated data.

310. Jiracek, G. R., and Smith, Christian, 1975, Deep resistivity investigations at two known geothermal resource areas (KGRAS) in New Mexico, Radium Springs and Lightning Dock, in Tectonics and mineral resources of southwestern North America: New Mexico Geological Society Special Publication No. 6, p. 71-76.

Geothermal, Geophysics, Tabulated data. 
311. Jiracek, G. R., Gustafson, E. P., and Parker, M. D., 1982 , Geophysical exploration for geothermal prospects west of Albuquerque, New Mexico, in Guidebook of Albuquerque Country II: New Mexico Geological Society, 33rd Field Conference, p. 333-342.

Geology, Geothermal, Geophysics.

312. Jiracek, G. R., Smith, Christian, and Dorn, G. A., 1975, Deep geothermal exploration in New Mexico using electrical resistivity, in Proceedings, Second United Nations symposium on the development and use of geothermal resources, San Francisco, California, USA, May 20-29, 1975: U.S. Government Printing Office, v. 2, p. $1095-1102$.

Geology, Geothermal, Geophysics, Tabulated data.

313. Jiracek, G. R., and others, 1975, Geothermal resistivity investigations in New Mexico [abs.]: American Association of Petroleum Geologists Rocky Mountain Section Annual Meeting, v. 59, no. 5, p. 912-913.

Geology, Geothermal, Geophysics.

314. Jobin, D. A., 1962, Relation of the transmissive character of the sedimentary rocks of the Colorado Plateau to the distribution of uranium deposits: U.S. Geological Survey Bulletin $1124,152 \mathrm{p}$.

Geology, Hydrology, Tabulated data.

315. John, E. C., Enyart, Eugene, and Purtymun, W. D., 1967 , Records of wells, test holes, springs, and surface-water stations in the Los Alamos area, New Mexico: U.S. Geological Survey Open-File Report 67-123, 129 p. Geology, Geothermal, Geochemistry and geothermometry, Hydrology, Tabulated data.

316. Johnson, A. I., 1965, Determination of hydrologic and physical properties of volcanic rocks by laboratory methods, in Dr. D. N. Wadia Commemorative Volume: Calcutta, India, Mining Geology and Metallurgical Institute of India, p. 49-66.

Geology, Hydrology, Geophysics. 
317. Johnson, R. B., and Read, C. B., eds., 1952, Guidebook of Rio Grande Country: New Mexico Geological Society, $3 r d$ Field Conference, 126 p.

Geology, Collected technical articles.

318. Johnson, Tom, 1983, Hot water power from the earth: Popular Science, v. 222 , no. 1, p. 70-74.

Geothermal.

319. Kaczmarek, Zdzislaw, 1977, Statistical methods in hydrology and meteorology: Published for the U.S. Geological Survey by the Department of the National Center for Scientific, Technical and Economic Information, 320 p.

Hydrology, Modeling methods and background, Textbook, Collected technical articles.

320. Kappelmeyer, 0., and Haenel, R., 1974, Geothermics with special reference to application: Berlin, Gebrueder Borntraeger, $238 \mathrm{p}$.

Geology, Geothermal, Hydrology, Geophysics,

Tabulated data.

321. Kassoy, D. R., and Goya1, K. P., 1979, Modeling heat and mass transfer at the Mesa geothermal anomaly, Imperial Valley, California: Lawrence Berkeley Laboratory LBL-8784, 171 p.

Geothermal, Modeling applications, Tabulated data.

322. Kaufman, A1vin, 1964, Geothermal power in economic evaluation: U.S. Bureau of Mines Information Circular $8230,24 \mathrm{p}$.

Geology, Geotherma1, Tabulated data.

323. Kaufman, E. L., and Siciliano, C. L. B., 1979, Environmental analysis of the Fenton Hill hot dry rock geothermal site: Los Alamos Scientific Laboratory LA-7830-HDR, $57 \mathrm{p}$.

Geology, Geotherma1, Ecology, Geophysics, Tabulated data. 
324. Ke11er, C. E., and Davis, A. H., 1973, The calculation of steam flow and hydraulic fracturing in a porous medium with KRAK code [abs.]: American Geophysical Union Transactions, v. 54, no. 11 , p. 1209 .

Geology, Geothermal, Geochemistry and geothermometry, Hydrology, Geophysics.

325. Ke1ler, M. D., 1968, Geologic studies and material property investigations of Mesita de Los Alamos: Los Alamos

Scientific Laboratory LA-3728, 49 p.

Geology, Geophysics, Tabulated data.

326. Keller, M. D., and others, 1968, Ground vibration

characteristics of Mesita de Los Alamos, in International symposium on wave propagation and dynamic properties of earth materials: Albuquerque, N. Mex., University of

New Mexico Press, p. 469-482.

Geophysics.

327. Kelley, V. C., 1948, Geology and pumice deposits of the Pajarito Plateau, Sandoval, Santa Fe, and Rio Arriba Counties: Albuquerque, N. Mex., University of New Mexico, $16 \mathrm{p}$. , maps in pocket.

Geology.

328 .

1952, Tectonics of the Rio Grande depression of central New Mexico, in Guidebook of Rio Grande Country: New Mexico Geological Society, 3rd Field Conference, p. 93-105. Geology, Geophysics.

329 . 1954, Tectonic map of a part of the upper Rio Grande area, New Mexico: U.S. Geological Survey 0il and Gas Investigations Map 157, scale 1:190,080, 1 sheet. Geology.

330 . 1970 , Highlights of the Rio Grande depression [abs.], in Guidebook of Tyrone-Big Hatchet Mountains-Florida Mountains region: New Mexico Geological Society, 21 st Field Conference, p. 157 . Geology. 
331. Kelley, V. C., and Clinton, N. J., 1980, Fracture systems and tectonic elements of the Colorado Plateau: Albuquerque, N. Mex., University of New Mexico Press, 456 p. Geology.

332. Ke1ley, V. C., and Kudo, A. M., 1978, Volcanos and related basalts of the Albuquerque Basin, New Mexico: New Mexico Bureau of Mines and Mineral Resources Circular 156,30 p. Geology, Tabulated data.

333. Kelley, V. C., Baltz, E. H., Jr., and Bailey, R. A., 1961, Road $\log$, Jemez Mountains and vicinity, in Guidebook of Albuquerque Country: New Mexico Geological Society, $12 \mathrm{th}$ Field Conference, p. 47-62.

Geology.

334. Ke11y, Clyde, and Anspach, E. V., 1913, A preliminary study of the waters of the Jemez Plateau, New Mexico: Albuquerque, N. Mex., University of New Mexico, Chemical Series Bulletin, v. 1, no. 1, 72 p.

Hydrology, Tabulated data.

335. Ke11y, P. P., compiler, 1968, Geologic studies and material properties investigations of Mesita de Los Alamos: Los Alamos Scientific Laboratory LA-3728, 49 p. Geology.

336. Ke11y, T. E., 1975, Evaluation of monitoring of radioactive solid-waste burial sites at Los Alamos, New Mexico: U.S. Geological Survey Open-File Report 75-406, 82 p.

Geology, Geochemistry and geothermometry, Hydrology, Ecology

337. Kennon, F. W., 1960, Hydrology of Cornfield Wash, Sandoval County, New Mexico, 1951-1955: U.S. Geological Survey Water-Supply Paper 1475-B, $103 \mathrm{p}$.

Geology, Hydrology, Tabulated data.

338. Kerr, R. A., 1982, Extracting geothermal energy can be hard: Science, v. 218, p. 668-669.

Geothermal. 
339. Keys, W. S., 1968, We11-logging in ground-water hydrology: Ground Water, v. 6, no. 1, p. 10-18.

Geology, Geophysics.

340. Kintzinger, P. R., 1976, Geophysical measurements at Fenton Hill [abs.]: American Geophysical Union Transactions, v. 57 , no. 4, p. 349 .

Geology, Hydrology, Geophysics.

341. Kintzinger, P. R., and others, 1978 , Mise-a-la-masse detection and modeling of hydraulic fractures at LASL geothermal site [abs.]: Society of Exploration Geophysicists, $48 \mathrm{th}$ Annual Meeting, p. 107 .

Geology, Geothermal, Hydrology, Modeling applications.

342 .

1978, Seismic reflection surveys near LASL

geothermal site: Los Alamos Scientific Laboratory

Informal Report LA-7228-MS, 17 p.

Geology, Geotherma1, Geophysics.

343. Kirkpatrick, T. 0., 1965, The economic and social value of hunting and fishing in New Mexico: Albuquerque, N. Mex., University of New Mexico, Bureau of Business Research, $94 \mathrm{p}$.

Hydrology, Ecology.

344. Koenig, J. B., 1970, Geothermal exploration in the Western United States, in Proceedings of the United Nations symposium on the development and utilization of geothermal resources, Pisa (Italy), September 22 0ctober 1, 1970: Geothermics Internationa1 Journal of Geothermal Research, Special Issue 2, part 1, p. 1-13. Geotherma1, Geochemistry and geothermometry, Tabulated data.

345. Kolstad, C. D., and McGetchin, T. R., 1978, Therma1 evolution models for the Valles Caldera with reference to a hot-dry-rock geothermal experiment: Journal of Volcanology and Geothermal Research, v. 3, p. 197-218. Geology, Geothermal, Modeling applications, Tabulated data. 
346. Kolstad, C. D., Albright, J. N., and McGetchin, T. R., 1975, Numerical studies of the thermal evolution of intrusions in relationship to observed temperatures in GT-2 [abs.]: American Geophysical Union Transactions, v. 56 , no. 4. p. 461 . Geology, Geotherma1, Geophysics, Modeling applications.

347. Ko1stad, C. D., McGetchin, T. R., and Laugh1in, A. W., 1976, Pluton thermal evolution modeling and observations in GT-2 [abs.]: American Geophysical Union Transactions, v. 57 , no. 4, p. 350 .

Geology, Geothermal, Geochemistry and geothermometry, Hydrology.

348. Koopman, F. C., and Ba11ance, W. C., 1968, Hydrologic tests in hole GB-1, Project Gasbuggy, Rio Arriba County, New Mexico: U.S. Department of Energy Report PNE-G-26, $33 \mathrm{p}$.

Geology, Hydrology, Tabulated data.

349 . 1968, Hydrologic tests in hole GB-2, Project Gasbuggy, Rio Arriba County, New Mexico [abs.]: Petroleum Abstracts, v. 9, no. 22 , p. 1439 . Geology, Geothermal.

350. Koster, W. J., 1957, Guide to fishes of New Mexico: Albuquerque, N. Mex., University of New Mexico Press, $116 \mathrm{p}$. Hydrology, Ecology.

351. Kott1owski, F. E., 1961 , Pennsy1vanian rocks in north-central New Mexico, in Guidebook of Albuquerque Country: New Mexico Geological Society, 12 th Field Conference, p. 97-104. Geology.

352. Kott1owski, F. E., and others, 1965, Quaternary geology of the Southwest, in The Quaternary of the United States [revised volume]: Princeton, N.J., Princeton University Press, p. 287-298.

Geology. 
353. Kron, Andrea, and Heiken, Grant, 1980, Geothermal gradient map of the conterminous United States: Los Alamos Scientific Laboratory LA-8476-MAP, scale $1: 5,000,000,1$ sheet.

Geotherma1, Geophysics.

354. Kruger, Paul, and 0tte, Care1, 1973, Geothermal energy: Stanford, Calif., Stanford University Press, 300 p. Geothermal, Modeling methods and background, Bibliography, Textbook, Collected technical articles, Tabulated data.

355. Kruger, Pau1, Stoker, A. K., and Umana, A., 1979, Radon in geothermal engineering: Geothermics, v . 5, p. 13-19.

Geothermal, Geochemistry and geothermometry.

356. Kudo, A. M., 1974, Outline of the igneous geology of the Jemez Mountain Volcanic Field, in Guidebook of Ghost Ranch: New Mexico Geological Society, $25 t h$ Field Conference, p. 287-289. Geology.

357. Kunk1er, J. L., 1969, Measurement of atmospheric pressure and subsurface gas pressure in the unsaturated zone of the Bandelier Tuff, Los Alamos, New Mexico, in Geological Survey Research 1969, Chapter D: U.S. Geological Survey Professional Paper 650-D, p. D283-D287.

Geology, Geochemistry and geothermometry, Geophysics.

358 . 1969 , The sources of carbon dioxide in the zone of areation of the Bandelier Tuff near Los Alamos, New Mexico, in Geological Survey Research 1969, Chapter B: U.S. Geological Survey Professional Paper 650-B, P. B $185-B 188$.

Geochemistry and geothermometry, Geophysics, Tabulated data.

359. Kutina, Jan, 1969, Hydrothermal ore deposits in the Western United States, A new concept of structural control of distribution: Science, v. 165, p. 1113-1119.

Geology, Geothermal, Hydrology. 
360. Lakatos, Stephen, 1976, Annealing characteristics of fission tracks in kyanite [abs.]: American Geophysical Union Transactions, v. 57, no. 4, p. 352 .

Geology, Geochemistry and geothermometry, Geophysics.

361. Lambert, P. W., 1966, Notes on the Late Cenozoic geology of the Taos-Questa area, New Mexico, in Guidebook of Taos-Raton-Spanish Peaks Country ( Colorado): New Mexico Geological Society, 17 th Field Conference, p. 43-50.

Geology, Tabulated data.

362. Lambert, S. J., and Epstein, Samue1, 1969, Stable isotope studies of an active hydrothermal system in New Mexico [abs.]: American Geophysical Union Transactions, v. 56, no. 6, p. 460 .

Geothermal, Geochemistry and geothermometry, Tabulated data.

363 . 1980 , Stable isotope investigations of an active geothermal system in Valles Caldera, Jemez Mountains, New Mexico: Journal of Volcanology and Geothermal Research, v. 8 , p. 111-129. Geothermal, Geochemistry and geothermometry, Tabulated data.

364. Lamers, M. D., 1979, Measurement requirements and methods for geothermal reservoir system parameters, an appraisal: Lawrence Berkeley Laboratory LBL-9090, 42 p. Geothermal.

365. Laney, Randy, and Laughlin, A. W., 1981, Natural annealing of pleochroic haloes in biotite samples from deep drill holes, Fenton Hill, New Mexico: Geophysical Research Letters, v. 8, no. 5, p. 501-504.

Geothermal, Geophysics.

366. Langhorst, G. J., 1980, Preliminary study of the potential environmental concerns associated with surface waters and geothermal development of the Valles Caldera: Los Alamos Scientific Laboratory Informal Report LA-8389-MS, 13 p. Geothermal, Geochemistry and geothermometry, Hydrology, Ecology, Tabulated data. 
367. Lanphere Reporting Service, 1980, Hearing before the New Mexico Public Service Commission, Santa Fe, New Mexico, in the matter of petition of the Public Service Company of New Mexico for authorizations necessary to participate in Baca Unit 1: Santa Fe, N. Mex., Lanphere Reporting Service, $99 \mathrm{p}$. Hydrology.

368. Larsen, E. S., III, 1958, Thorium in igneous rocks

(California-New Mexico), in Geologic investigations of radioactive deposits, semiannual progress report, Dec. 1, 1957 to May 31, 1958: U.S. Geological Survey Trace Elements Investigations 740, p . 308-310. Geology, Geochemistry and geothermometry, Tabulated data.

369. Lasseter, T. J., Witherspoon, P. A., and Lippmann, M. J., 1975 , The numerical simulation of heat and mass transfer in multidimensional two-phase geothermal reservoirs, in Proceedings, Second United Nations symposium on the development and use of geothermal resources, San Francisco, California, USA, May 20-29, 1975: U.S. Government Printing office, v. 3, p. 1715-1725.

Geothermal, Modeling methods and background, Modeling applications.

370. Lattanner, A. V., 1980, Va11es Ca1dera geophysical interpretation: Los Angeles, Calif., Union 0il Company of California, Union Geothermal Division, 5 p. and figures. Geotherma1, Geophysics.

371. Laugh1in, A. W., 1975, Hot dry rock tested for geotherma1 energy: Geotimes, v. 20, no. 3, p. 20-21.

Geotherma1, Geochemistry and geothermometry, Geophysics.

372 . 1981 , The geothermal system of the Jemez Mountains, New Mexico and its exploration, in Rybach, L., and Muffler, L. I. P., eds., Geotherma1 systems, principles and case histories: New York, John Wiley, p. 295-320. Geology, Geothermal, Review articles. 
373. Laughlin, A. W., Brookins, D. G., and Causey, J. D., 1972 , Late Cenozoic basalts from the Bandera Lava Field, Valencia County, New Mexico: Geological Society of America Bulletin, v. 83, p. 1543-1552. Geology.

374. Laughlin, A. W., and Eddy, Andrea, 1977, Petrography and geochemistry of Precambrian rocks from GT-2 and EE-1: Los Alamos Scientific Laboratory Informal Report LA-5124-MS, $50 \mathrm{p}$. Geology, Geochemistry and geothermometry.

375. Laugh1in, A. W., and West, F. G., 1977, Hot dry rock (HDR) geothermal energy, exploitation and exploration [abs.]: American Association of Petroleum Geologists Bulletin, v. 61, no. 5, p. 807-808. Geothermal, Hydrology.

376. Laughlin, A. W., Pettitt, R. A., and West, F. G., 1975 , Current status of the Los Alamos dry hot rock geothermal energy experiment [abs.]: Economic Geology, v.70, no.7, p. 1323 .

Geothermal.

377 . 1977, Status of the Los Alamos experiment to extract geothermal energy from hot dry rock: Geology, v. 5, no. 4, p. 237-240. Geotherma1.

378. Laughlin, A. W., and others, 1975, Current status of the Los Alamos hot dry rock geothermal experiment [abs.]: Geological Society of America Abstracts with Programs, v. 7 , no. 7, p. 1162-1163. Geotherma1.

379 . 1979, Late Cenozoic volcanism of the central Jemez zone, Arizona-New Mexico: Isochron West, p. 5-8. Geology. 
380 . 1982, Tectonic setting and history of Late-cenozoic volcanism in west-central New Mexico: Guidebook of Albuquerque Country II, New Mexico Geological Society, 33 rd Field Conference, p. 279-284. Geology, Geothermal.

381 . 1983 , Geology of the Fenton Hill, New Mexico, hot dry rock site: Journal of Volcanology and Geothermal Research, v. 15, p. 21-40. Geology, Geothermal.

382. Laumbach, D. D., 1975, A high-accuracy, finite-difference technique for treating the convection-diffusion equation: Society of Petroleum Engineers, v. 15, no. 6, p. 517-531.

Geothermal, Modeling methods and background.

383. Lawrence Berkeley Laboratory, 1975, Proceedings, Second United Nations symposium on the development and use of geothermal resources, San Francisco, California, USA, May 20-29, 1975: U.S. Government Printing office, 3 volumes, 2466 p.

Geology, Geothermal, Geochemistry and geothermometry, Bibliography, Collected technical articles, Tabulated data.

384 . 1978 , Geothermal exploration technology, Annual Report, 1978: Lawrence Berkeley Laboratory LBL-8603, $42 \mathrm{p}$.

Geotherma1, Geochemistry and geothermometry, Geophysics, Modeling methods and background, Modeling applications, Collected technical articles.

385. Lee, W. T., 1907, Note on the red beds of the Rio Grande region in central New Mexico: Journal of Geology, v. 15, p. $52-58$. Geology. 
386. Levitte, D., and Gambi11, D. T., 1980, Geotherma1 potential of west-central New Mexico from geochemical and thermal gradient data: Los Alamos Scientific Laboratory LA-8608-MS, 102 p.

Geothermal, Geochemistry and geothermometry, Geophysics, Tabulated data.

387. Lewis, T. J., and Beck, A. E., 1977, Analysis of heat flow data - Detailed observations in many holes in a small area: Tectonphysics, v. 41, p. 41-59.

Geothermal, Geophysics, Modeling methods and background.

388. Lindgren, Waldemar, 1908 , A recent vein at ojo Caliente,

New Mexico [abs.]: Science, new series, v. 27, p. 348-349. Geology, Geotherma1.

389 . 1910, The hot springs at ojo Caliente and their deposits: Economic Geology, v. 5, p. 22-27. Geology, Geothermal, Geochemistry and geothermometry, Tabulated data.

390. Lipman, P. W., Pal1ister, J. S., and Sargent, K. A., 1979 , Geologic map of the Mount Taylor Quadrangle, Valencia County, New Mexico: U.S. Geological Survey Geologic Quadrangle Map GQ-1523, scale $1: 24,000,1$ sheet. Geology.

391. Lipman, P. W., Prostka, H. J •, and Christiansen, R. L., 1972 , Cenozoic volcanism and plate-tectonics evolution of the Western United States, I. Early and Middle Cenozoic: Philosophical Transactions of the Royal Society of London, Series A, v. 271, no. 1213, p. 217-248. Geology, Geophysics, Tabulated data.

392. Long, P. E., 1974, Contrasting types of Precambrian granite rocks in the Dixon-Peñasco area, northern New Mexico, in Guidebook of Ghost Ranch: New Mexico Geological Societ $\bar{y}$, 25th Field Conference, p. 101-108. Geology, Tabulated data. 
393. Lookingbi11, J. L., 1953, Stratigraphy and structure of the Gallinas Uplift, Rio Arriba County, New Mexico:

Albuquerque, N. Mex., University of New Mexico, unpublished M.S. thesis, $118 \mathrm{p}$. Geology.

394 . 1955, Geology of the Gallinas Uplift, Rio Arriba County, New Mexico: The Compass of Sigma Gamma Epsilon, v. 33, no. 1, p. 40-54. Geology.

395. Los Alamos National Laboratory, 1981, Environmental surveillance at Los Alamos during 1980: Los Alamos Nationa1 Laboratory LA-8810-ENV, 153 p.

Geology, Hydrology, Ecology, Tabulated data.

396.

1982, Environmental surveillance at Los Alamos during 1981: Los Alamos National Laboratory LA-9349-ENV, $166 \mathrm{p}$. Geology, Hydrology, Ecology, Tabulated data.

397 . 1982, Va11es Ca1dera workshop, October 5-7, 1982:

Los Alamos National Laboratory, Earth and Space Sciences Division, $14 \mathrm{p}$.

Geothermal, Review articles, Collected technical articles, Tabulated data.

398. Los Alamos Scientific Laboratory, 1962, U1tra high temperature reactor experiment (UHTREX) hazard report:

Los Alamos Scientific Laboratory LA-2689, l64 p. Ecology.

399 .

1977, Environmental surveillance at Los Alamos during 1976: Los Alamos Scientific Laboratory Informa1 Report LA-6801-MS, 60 p. Hydrology, Ecology, Tabulated data.

400. 1978, Environmental surveillance at Los Alamos during 1977: Los Alamos Scientific Laboratory Informal Report LA-7263-MS, 83 p. Geology, Hydrology, Ecology, Tabulated data. 
401 .

1978, Geothermal energy, furnace at our feet: Los Alamos Scientific Laboratory LASL-77-23, 11 p.

Geology, Geothermal, Geophysics, Tabulated data.

402 .

1978, Hot dry rock geothermal energy development project, annual report fiscal year 1977: Los Alamos Scientific Laboratory Progress Report LA-7109-PR, 294 p. Geothermal, Geophysics.

403

1979 , Environmental survelllance at Los Alamos during 1978: Los Alamos Scientific Laboratory LA-7800-ENV, $110 \mathrm{p}$.

Geology, Hydrology, Ecology, Tabulated data.

404 .

1979, Expanding the hot dry rock program (Reprinted From "The Atom," June 1979): Los Alamos Scientific

Laboratory LASL-79-60, 16 p.

Geothermal, Collected technical articles.

405 . 1980 , Environmental surveillance at Los Alamos during 1979: Los Alamos Scientific Laboratory LA-8200-ENV, $136 \mathrm{p}$.

Geology, Hydrology, Ecology, Tabulated data.

406 . 1980 , Preprints, Geothermal Resources Council Annual Meeting, Salt Lake City, Utah, September 9-11, 1980: Los Alamos Scientific Laboratory LASL-80-36, 35 p. Geology, Geothermal, Geochemistry and geothermometry, Hydrology, Geophysics, Collected technical articles, Tabulated data.

407 . n.d., Environmental aspects of hot dry geothermal energy (pamphlet): Los Alamos Scientific Laboratory, 8 p. Geology, Geothermal, Ecology, Geophysics.

408. Lovering, T. G., 1956, Description of mines and prospects, Sandoval County, in Radioactive deposits in New Mexico: U.S. Geological Survey Bulletin 1009-L, p. 357-366. Geology, Geothermal, Geochemistry and geothermometry, Tabulated data. 
409. Luedke, R. G., and Smith, R. L., 1978, Map showing distribution, composition, and age of Late-Cenozoic volcanic centers in Arizona and New Mexico: U.S. Geological Survey Miscellaneous Investigation Series Map I-1091-A, scale $1: 1,000,000,2$ sheets. Geology

410. Machette, M. N., 1978, Dating Quaternary faults in the Southwestern United States by using buried calcic paleosols: U.S. Geological Survey Journal of Research, v. 6 , no. 3, p. 369-381.

Geology.

411. Maddox, J. D., and Wilbur, A. C., 1979, Baca geothermal demonstration power plant data gathering, evaluation, and dissemination: Geothermal Resources Council Transactions, v. 3, p. 405-408.

Geothermal, Hydrology.

412. Mahon, W. A. J., 1970 , Chemistry in the exploration and exploitation of hydrothermal systems, in Proceedings of the United Nations symposium on the development and utilization of geothermal resources, Pisa (Italy), September 22-0ctober 1, 1970: Geothermics Internationa1 Journal of Geothermal Research, Special Issue 2, part 2, p. $1310-1322$.

Geothermal, Geochemistry and geothermometry, Hydrology.

413. Mangold, D. C., 1980, A discussion of the comments on the hydrology of the Baca Site GDPP: Lawrence Berkeley Laboratory Report LBL-18109, $37 \mathrm{p}$. Hydrology, Review articles.

414. Manley, Kim, 1982, Geologic map of the Cañones Quadrangle, Rio Arriba County, New Mexico: U.S. Geological Survey Miscellaneous Field Studies Map MF-1440, scale 1:24,000, 1 sheet.

Geology.

415. Manley, Kim, and Lane, M. E., 1983, Mineral resource potential and geologic map of the Caballo and Polvadera roadless areas, Los Alamos and Rio Arriba Counties, New Mexico: U.S. Geological Survey Miscellaneous Field Studies Map MF-1516, scale $1: 62,500,1$ sheet, 4 p. text.

Geology • 
416. Mansfie1d, G. R., 1918, Sulphur in Jemez Canyon, Sandoval County: U.S. Geological Survey Mineral Resources 1918, part 2, p. 367-369.

Geology, Geochemistry and geothermometry.

417 . 1918, Sulphur in Jemez Canyon: Engineering Mining Journal, v. 106 , p. 449 .

Geology, Geochemistry and geothermometry.

418. Mansure, A. J., and Reiter, Marshall, n.d., A vertical ground-water movement correction for heat flow: New Mexico Bureau of Mines and Mineral Resources, 28 p. Hydrology, Geophysics.

419. Martin, J. C., 1975, Analysis of internal steam drive in geothermal reservoirs: Journal of Petroleum Technology, p. 1493-1499.

Geothermal, Modeling methods and background.

420. Maxwe11, B. W., 1959, Availability of ground water for irrigation near Zia Pueblo, Sandoval County, New Mexico: U.S. Geological Survey Open-File Report 60-97, 17 p. Geology, Hydrology, Tabulated data.

421. Maxwe11, J. C., 1979, Geothermal exploration methods and results--Inland states, in LASL Reprints from a symposium of geothermal energy and its direct uses in the Eastern United States: Los Alamos Scientific Laboratory LA-UR-79-665, p. 1-2. Geotherma1.

422. Mazor, E., and others, 1980, Mixing models and ionic geothermometers applied to warm (up to 60 degrees Celsius) springs, Jordan Rift Valley, Israel: Journal of Hydrology, v. 45, p. 1-19.

Geothermal, Geochemistry and geothermometry, Tabulated data. 
423. McGetchin, T. R., 1975, The mechanism of caldera forming ash-blast volcanic eruptions [abs.]: American Geophysical Union Transactions, v. 56, no. 6, p. 461 .

Geology, Geophysics.

424. McGetchin, T. R., compiler, 1975, Solid earth geosciences research activities at Los Alamos Scientific Laboratory, Ju1y 1 - December 31, 1974: Los Alamos Scientific Laboratory, $93 \mathrm{p}$. Geology, Geophysics.

425. McKenzie, W. F., and Truesde11, A. H., 1977, Geotherma1 reservoir temperatures estimated from the oxygen isotope compositions of dissolved sulfate and water from hot springs and shallow drill holes: Geothermics, v. 5, p. $51-61$.

Geotherma1, Geochemistry and geothermometry, Tabulated data.

426. McPhar Geophysics, 1973, Report on the reconnaissance resistivity survey of the Baca property, Valles Caldera area, Sandova1 County, New Mexico: consultant report for Union $0 i 1$ Company of California, Union Geothermal

Division, Los Angeles, California, $7 \mathrm{p}$.

Geothermal, Geochemistry and geothermometry, Hydrology, Geophysics.

427 .

1973, Supplemental report on the reconnaissance resistivity and Schlumberger depth sounding surveys of the Baca property, Valles Caldera area, Sandoval County, New Mexico: consultant report for Union oil Company of California, Union Geothermal Division, Los Angeles, California, 16 p.

Geotherma1, Geochemistry and geothermometry, Hydrology, Geophysics, Tabulated data.

428. Mercer, James W., 1973, Finite element approach to the modeling of hydrothermal systems: Urbana-Champaign, I11., University of Illinois, unpublished Ph.D. thesis, $115 \mathrm{p}$. Geotherma1, Modeling methods and background, Modeling applications. 
429. Mercer, James W., and Faust, C. R., 1980, Ground-water modeling - An overview: Ground Water, v. 18, no. 2, p. $108-115$.

Hydrology, Modeling evaluation and documentation.

430 . 1980 , Ground-water modeling - Applications: Ground Water, v. 18, no. 5, p. 486-497. Modeling applications.

431 . 1980, Ground-water modeling - Mathematical models: Ground Water, v. 18, no. 3, p. 212-227. Modeling methods and background, Modeling applications, Modeling evaluation and documentation.

432 . 1980 , Ground-water modeling - Numerical models: Ground water, v. 18, no. 4, p. 395-409.

Modeling methods and background, Modeling applications, Modeling evaluation and documentation.

433 . 1980 , Ground-water modeling - Recent developments : Ground water, v. 18, no. 6, p. 569-577.

Modeling methods and background, Modeling applications, Modeling evaluation and documentation.

434. Mercer, James W., Faust, C. R., and Pinder, G. F., 1974 , Geothermal reservoir simulation, in Proceedings of the National science Foundation conference on research for the development of geothermal energy resources, Pasadena, California, September 23-25, 1974: National Science Foundation, p. 256-267.

Geothermal, Modeling methods and background.

435. Mercer, James W., Pinder, G. F., and Donaldson, I. G., 1975, A galerkin-finite element analysis of the hydrothermal system at Wairakei, New Zealand: Journal of Geophysical Research, v. 80, no. 17, p. 2608-2621.

Geothermal, Modeling applications. 
436. Mercer, Jerry W., 1967, Technical letter, Gasbuggy-3, inventory of wells and springs within a 10-mile radius of Project Gasbuggy, Rio Arriba County, New Mexico: U.S. Geological Survey open-file report, 13 . Hydrology, Tabulated data.

437 . 1967, Technical letter, Gasbuggy-4, Geology and hydrology of the Project Gasbuggy, Rio Arriba County, New Mexico: U.S. Geological Survey open-file report, 16 p. Geology, Hydrology, Tabulated data.

438 . 1969, Hydrology of Project Gasbuggy site, Rio Arriba County, New Mexico: Springfield, Va., U.S. Department of Commerce, U.S. Atomic Energy Commission Technical Information Service PNE-1013, $45 \mathrm{p}$. Geology, Hydrology.

439. Miller, F. L., Jr., and Zimmerman, D. E., 1982, Geothermal system failures, Implications for ground-water monitoring: Ground Water Monitoring Review, Spring 1982 , p. $23-29$.

Geotherma1, Hydrology.

440. Mize11, N. H., 1980, Inventory of geothermal leasing and driling activity in New Mexico: New Mexico Geology, November 1980 , p. 53-54.

Geothermal, Review articles.

441 .

1980 , Documentation for computerization of geothermal activity in New Mexico: New Mexico Bureau of Mines and Mineral Resources Open-File Report 121,27 p. Geothermal, Modeling methods and background.

442. Mortensen, J. J., 1978, Hot dry rock, A new geothermal energy source: Energy, v. 3, no. 5, p. 639-644. Geology, Geothermal. 
443. Mountain West Research, Inc., 1979, Socioeconomic analysis for the proposed geothermal project: consultant report for Union oil Company of California, Union Geothermal Division, Los Angeles, California, and Public Service Company of New Mexico, Albuquerque, New Mexico, 114 p. Geothermal, Ecology, Tabulated data.

444. Mourant, W. A., 1980, Hydrologic maps and data for Santa Fe County, New Mexico: New Mexico State Engineer Office Basic Data Report, 180 p.

Geology, Geochemistry and geothermometry, Hydrology, Tabulated data.

445. Muehlberger, W. R., 1960, Precambrian rocks of the Tusas Mountains, Rio Arriba County, New Mexico, in Guidebook of Rio Chama Country: New Mexico Geological Society, $11 \mathrm{th}$ Fie1d Conference, p. 45-47.

Geology.

446 . 1960 , Structure of the central Chama platform, northern Rio Arriba County, New Mexico, in Guidebook of Rio Chama Country: New Mexico Geologica1 Society, 11 th Field Conference, p. 103-110.

Geology.

447. Muehlberger, W. R., and others, 1960, Stratigraphy of the Chama Quadrangle, northern Rio Arriba County, New Mexico, in Guidebook of Rio Chama Country: New Mexico Geological Society, lith Field Conference, p. 93-102. Geology.

448. Muffler, L. I. P., and White, D. E., 1972, Geothermal Energy [reprint]: The Science Teacher, v. 39, no. 3. Geothermal, Review articles.

449. Muir, K. S., and Coplen, T. B., 1981, Tracing ground-water movement by using the stable isotopes of oxygen and hydrogen, Upper Penitencia Creek alluvial fan, Santa Clara Valley, California: U.S. Geological Survey WaterSupply Paper 2075,18 p.

Geothermal, Geochemistry and geothermometry, Hydrology, Tabulated data. 
450. Murphy, H. D., 1976, Extracting energy from hydraulical1y-fractured geothermal reservoirs [abs.]: American Geophysical Union Transactions, v. 57, no. 4 , p. 349-350.

Geology, Geothermal, Geophysics.

451. 1978, Thermal stress cracking and the enhancement of heat extraction from fractured geothermal reservoirs: Los Alamos Scientific Laboratory Informal Report LA-7235-MS, $17 \mathrm{p}$. Geotherma1, Geophysics.

452. Murphy, H. D., and Tester, J. W., 1979, Heat production from a geothermal reservoir formed by hydraulic fracturing - Comparison of field and theoretical results: Dallas, Tex., Society of Petroleum Engineers SPE 8265 , $10 \mathrm{p}$. Geothermal, Geophysics, Modeling applications •

453. Murphy, H. D., Tester, J. W., and Potter, R. M., n.d., Comparison of two hot dry rock geothermal reservoirs [preprint]: Los Alamos Scientific Laboratory Preprint, 7 p. Geotherma1.

454. Murphy, H. D., and others, 1980, Preliminary evaluation of the second hot dry rock geothermal energy reservoir, Results of phase 1, run segment 4: Los Alamos Scientific Laboratory Informal Report LA-8354-MS, 88 p.

Geothermal.

455. Naeser, C. W., and Forbes, R. B., 1976, Variation of fission track ages with depth in two deep drill holes [abs.]: American Geophysical Union Transactions, v. 57 , no. $4, \mathrm{p} .358$.

Geology, Geotherma1, Geochemistry and geothermometry, Hydrology, Geophysics.

456. Nakata, J. K., and others, 1982, Quaternary fault map of the Basin and Range and the Rio Grande Rift Provinces, Western United States: U.S. Geological Survey open-File Report 82-579, scale $1: 2,500,000,2$ oversized sheets. Geology. 
457. Narasimhan, T. N., and Witherspoon, P. A., 1979, Geothermal well testing: Journal of Hydrology, v. 43, p. 537-553. Geothermal, Hydrology.

458. Neher, L. I., 1980, Origin and occurrence of pumice in New Mexico: New Mexico Professional Engineer and Contractor, v. 3, no. 3, p. 7-9. Geology.

459. Nelson, Jack, 1975, Geothermal update - Putting on the pressure: The Atom, v. 12, no. 1, p. 16-18.

Geothermal.

460. New Mexico Energy Institute, 1980, Geothermal resources of New Mexico, 1980: New Mexico Energy Institute Map, 1 sheet.

Geothermal.

461. New Mexico Interstate Stream Commission and New Mexico State Engineer Office, 1974 , County profile, Sandoval County, Water resources assessment for planning purposes: New Mexico Interstate Stream Commission and New Mexico State Engineer office, 30 p. Hydrology, Tabulated data.

462 . 1975, County profile, Los Alamos County, Water resources assessment for planning purposes: New Mexico Interstate Stream Commission and New Mexico State Engineer office, $30 \mathrm{p}$. Hydrology, Tabulated data.

463. New Mexico State Engineer Office, 1966 , Nambe-Pojoaque-Tesuque section of the upper Rio Grande hydrographic survey report: New Mexico State Engineer Office, $786 \mathrm{pe}, 30$ sheets and 2 appendices.

Hydrology.

464 . 1967 , Water resources of New Mexico, occurrence, development and use: New Mexico state Planning office, $321 \mathrm{p}$. Geology, Hydrology, Tabulated data. 
465 .

1980 , In the matter of application of Marcel and

Thomas Abousleman for an alternate point of diversion and new place and purpose of use from surface water to

geothermal water and to appropriate the underground waters of the State of New Mexico (No. 02541B and RG-32624):

New Mexico State Engineer Office, 9 p.

Geothermal, Hydrology, Tabulated data.

466. Newton, C. A., and others, 1976, LASL seismic programs in the vicinity of Los Alamos, New Mexico: Los Alamos

Scientific Laboratory Informal Report LA-6406-MS, 42 p.

Geology, Geophysics.

467. Nishimura, Masakichi, Nakaya, Syu, and Tanaka, Kazuhiko, 1973 , Boron in the atmosphere and precipitation. Is the sea the source of atmospheric boron?, in Proceedings of symposium on hydrogeochemistry and biogeochemistry, Tokyo, Japan, September 7-9, 1970: Washington, D.C., The Clark Company, v. 1, p. 547-557.

Geochemistry and geothermometry, Hydrology, Tabulated data.

468. Norman, D. I., Alexander, E. C., Jr., and Sawkins, F. J., 1976, Helium in cordierites, A possible indicator of $10 \mathrm{w}$ temperature metamorphic events [abs.]: American

Geophysica 1 Union Transactions, v. 57, no. 4, p. 352.

Geology, Geothermal, Geochemistry and geothermometry, Geophysics.

469. Norman, D. I., and Bernhardt, C. A., 1982, Assessment of geothermal reservoirs by analysis of gasses in thermal waters: Las Cruces, N. Mex., New Mexico Energy Institute EMD 2-68-2305, $130 \mathrm{p}$.

Geotherma1, Geochemistry and geothermometry, Tabulated data.

470. North American Rockwe11 Corporation, 1972, Airborn infrared geothermal exploration - Valles Caldera, Jemez Mountains, New Mexico: consultant report for Union 0il Company of California, Union Geothermal Division, Los Angeles, California, 56 p.

Geology, Hydrology, Geophysics. 
471. Northrop, S. A., 1959, Minerals of New Mexico [revised edition ]: Albuquerque, N. Mex., University of New Mexico Press, $665 \mathrm{p}$.

Geology, Text book.

472 . 1961 , Mississippian and Pennsylvanian fossils of the Albuquerque Country, in Guidebook of Albuquerque Country: New Mexico Geological Society, $12 \mathrm{th}$ Field Conference, p. 105-112. Geology

473. Northrop, S. A., ed., 1961, Guidebook of Albuquerque Country: New Mexico Geological Society, 12 th Field Conference, $199 \mathrm{p}$. Geology, Collected technical articles.

474. Northrop, S. A., and Read, C. B., eds., 1966, Guidebook of Taos-Raton-Spanish Peaks Country: New Mexico Geological Society, 17 th Field Conference, $128 \mathrm{p}$. Geology, Collected technical articles.

475. Northrop, S. A., and Wood, G. H., 1950, General geology of northern New Mexico, in Guidebook for the fourth field conference of the Society of Vertebrate Paleontology in northwestern New Mexico: American Museum of Natural History and University of New Mexico, Albuquerque, New Mexico, p. 26-47.

Geology.

476. Norton, D. R., Friedman, Irving, and $01 \mathrm{mstead,F.H.,} 1981$, Ground temperature measurements: U.S. Geological Survey Professional Paper 1203,39 p.

Geothermal, Tabulated data.

477. O'Sullivan, M. J., 1981, A similarity method for geothermal well test analysis: Water Ressources Research, v. 17, no. 2, p. 390-398.

Geothermal, Modeling methods and background, Tabulated data. 
478. 01sen, K. H., and Chapin, C. E., eds., 1978, 1978

International symposium on the Rio Grande Rift, october 8-17, 1978, Santa Fe, New Mexico, USA, Program and abstracts: Los Alamos Scientific Laboratory Conference Proceedings LA-7487-C, 105 p.

Geology, Geothermal, Geochemistry and geothermometry, Hydrology, Tabulated data.

479. 01sen, K. H., and others, 1983, Seismic search for evidence of magma beneath the Jemez Mountains in the northern Rio Grande Rift [abs.]: Geological Society of America Abstracts with Programs, v. 15, no. 5, p. 381 . Geology, Geothermal, Geophysics.

480. Owen, D. E., 1969, The Dakota Sandstone of the eastern San Juan and Chama basins and its possible correlation across the southern Rocky Mountains: Mountain Geologist, v . 6 , no. 3, p. 87-92. Geology

481. Owen, L. B., and Jackson, D., 1976, Precipitation of amorphous silica from temperature-hypersaline geothermal brine [abs.]: American Geophysical Union Transactions, v. 67, p. 354 . Geothermal, Geochemistry and geothermometry.

482. Ozima, M., and others, 1967, Paleomagnetism and potassium-argon ages of some volcanic rocks from the Rio Grande Gorge, New Mexico: Journal of Geophysical Research, v. 72, no. 10, p. 2615-2621. Geology, Geochemistry and geothermometry, Geophysics, Tabulated data.

483. Pearson, Chris, and Goff, F. E., 1981, A Schlumberger resistivity study of the Jemez springs region of northwestern New Mexico: Geothermal Resources Council Transactions, v. 5, p. 119-122.

Geology, Geothermal, Geochemistry and geothermometry, Hydrology, Geophysics, Tabulated data. 
484. Pearson, Chris, and others, 1982, Rock failure during massive hydraulic stimulation of the Baca location geothermal reservoir: Los Alamos National Laboratory LA-UR-82-1578, $5 \mathrm{p}$. Geotherma1, Geophysics.

485. Pearson, F. J., Jr., Fisher, D. W., and Plummer, L. N., 1978 , Correction of ground-water chemistry and carbon isotope composition for effects of CO2 outgasing: Geochimica et Cosmochimica Acta [Pergamon Press, Great Britain], v. 42, p. 1799-1807.

Geochemistry and geothermometry, Hydrology, Tabulated data.

486. Pearson, F. J., Jr., and Rightmire, C. T., 1980, Su1phur and oxygen isotopes in aqueous sulphur compounds, in Fritz, P., and Fontes, J. C., eds., Handbook of environmental isotope geochemistry, volume 1 , The terrestrial environmental, A.: New York, Elsevier Scientific Publishing Company, p. 228-258.

Geochemistry and geothermometry, Hydrology.

487. Perkins, P. C., 1973, Petrography and some rock types of the Precambrian basement near the Los Alamos Scientific Laboratory geothermal test site, Jemez Mountains, New Mexico: Los Alamos Scientific Laboratory LA-5129, 12 p. Geology, Tabulated data.

488. Peterson, H. V., 1962, Hydrology of small watersheds in western states: U.S. Geological Survey Water-Supply Paper $1475-\mathrm{I}, 217 \mathrm{p}$.

Geology, Hydrology, Tabulated data.

489. Pettitt, R. A., 1967, Cement stabilization of volcanic materials: Journal of Construction Division, v. 94 , no. CO2, p. 248-250.

Geology, Geophysics.

490 .

1975, Planning, drilling and logging of geothermal test hole GT-2, Phase 1: Los Alamos Scientific Laboratory Progress Report LA-5819-PR, $42 \mathrm{p}$. Geology, Geothermal, Hydrology, Geophysics, Tabulated data. 
491 .

1976, Environmental monitoring for the hot dry rock geothermal energy development project, annual report for the period July 1975-June 1976: Los Alamos Scientific Laboratory LA-6504-SR, $92 \mathrm{p}$. Geothermal, Ecology.

492 . 1977, Los Alamos hot dry rock geothermal energy project, in Geothermal, state of the art: Geothermal Research Council Transactions, v. 1, p. 241-244. Geothermal.

493 . 1978, Testing, planning and redrilling of geothermal test hole GT-2, Phases IV and V: Los Alamos Scientific Laboratory Progress Report LA-7586-PR, $60 \mathrm{p}$. Geotherma1.

494 .

1979, Hot dry rock program in the Eastern United States, in LASL Reprint from a symposium of geothermal energy and its direct uses in the Eastern United States: Los Alamos Scientific Laboratory LA-UR-79-602, p. 3-7. Geothermal.

495 . 1980 , Monitoring and repairing geothermal casing cement, A case history, in Preprints - Geothermal Resources Council Annual Meeting, Salt Lake City, Utah, September 9-11, 1980: Los Alamos Scientific Laboratory LASL $-80-36$, p. 29-32.

Geothermal, Geophysics.

496. Pilz, W. R., Sabo, D. G., and Wagner, W. L., 1979, Biotic inventory: Public Service Company of New Mexico, Environmental Affairs Department, Albuquerque, New Mexico, and Union oil Company of California, Union Geothermal Division, Los Angeles, California, 86 p. Ecology, Tabulated data.

497. Pinder, G. F., 1979 , State-of-the-art review of geothermal reservoir modeling: Lawrence Berkeley Laboratory LBL-9093, $144 \mathrm{p}$.

Geothermal, Modeling methods and background. 
498. Pinder, G. F., and Bredehoeft, J. D., 1968, Application of the digital computer for aquifer evaluation: Water Resources Research, v. 4, no. 5, p. 1069-1093.

Geology, Hydrology, Modeling methods and background, Modeling applications, Modeling evaluation and documentation, Tabulated data.

499. Pinder, G. F., Frind, E. O., and Papadopu1os, S. S., 1973, Functional coefficients in the analysis of ground-water flow: Water Resources Research, v. 9, no. l, p. 222-226. Hydrology, Modeling methods and background, Modeling applications, Modeling evaluation and documentation, Tabulated data.

500. Potter, J. M., 1978, Experimental permeability studies at elevated temperature and pressure of granitic rocks: Los Alamos Scientific Laboratory LA-7224, 101 p. Geology, Geothermal, Hydrology, Geophysics.

501. Potter, J. M., Balagna, J. P., and Char1es, R. W., 1976 , Permeability of a biotite monzogranite at elevated temperatures [abs.]: American Geophysical Union Transactions, v. 57 , no. 4, p. 353 .

Geology, Geothermal, Geochemistry and geothermometry, Hydrology, Geophysics.

502. Potter, R. M., 1972, Geothermal resources created by hydraulic fracturing in hot dry rock [abs.]: American Physics Society Bulletin, series 2, v. 17, p. 1099 . Geology, Geotherma1, Geophysics.

503. 1973, Heat flow of the Jemez Plateau: American Geophysical Union Transactions, v. 54, no. 1l, p. 1214 . Geology, Geothermal, Hydrology.

504. 1976, Characteristics of seismic events associated with hydraulic fracturing [abs.]: American Geophysical Union Transactions, v. 57, no. 4, p. 349. Geology, Geothermal, Geophysics. 
505. Potter, R. W., II, Shaw, D. R., and Haas, J. L., Jr., 1975, Annotated bibliography of studies on the density and other volumetric properties for major components in geothermal waters, 1928-1974: U.S. Geological Survey Bu11etin $1417,78 \mathrm{p}$.

Geology, Geothermal, Geochemistry and geothermometry, Hydrology, Geophysics, Bibliography.

506. Prats, M., 1966, The effect of horizontal fluid flow on thermally induced convection currents in porous mediums: Journal of Geophysical Research, v. 71, no. 20, p. 4835-4838.

Geothermal, Hydrology.

507. Price, H. S., Cavendish, J. C., and Varga, R. S., 1968 , Numerical methods of higher-order accuracy for diffusion-convection equations: Society of Petroleum Engineers Journal, v. 8, no. 3, p. 293.

Geothermal, Modeling methods and background.

508. Pritchett, J. W., 1980, Geothermal reservoir engineering computer code comparison and validation calculations using MUSHRM and CHARGR geothermal reservoir simulators (final report): U.S. Department of Energy DE-ACO3-80SF11451, 126 p.

Geothermal, Modeling evaluation and documentation.

509. Pritchett, J. W., Rice, M. H., and Riney, T. D., 1981, Baca geothermal project, Equation of state for water-carbon dioxide mixtures. Implications for Baca Reservoir: Systems, Science and Software consultant report for Union Geothermal Company of New Mexico (see Union Oil Company of California, Union Geothermal Division, Los Angeles, California) and the Public Service Company of New Mexico, Albuquerque, New Mexico, 53 p.

Geothermal, Geochemistry and geothermometry, Tabulated data. 
510. Pruess, Karsten, and Truesde11, A. H., 1980, A numerical simulation of the natural evolution of vapor-dominated hydrothermal systems, in Proceedings, $6 \mathrm{th}$ workshop, Geothermal reservoir engineering, December 16-18, 1980 : Stanford, Calif., Stanford University SPG-TR-50, $383 \mathrm{p}$.

Geology, Geothermal, Hydrology, Modeling methods and background, Modeling applications, Tabulated data.

511. Purtymun, W. D., 1966, Geology and hydrology of White Rock Canyon from otowi to the confluence of Frijoles Canyon, Los Alamos and Santa Fe Counties, New Mexico: U.S. Geological Survey open-file report, 27 p.

Geology, Geochemistry and geothermometry, Hydrology, Tabulated data.

512 . 1966, Geology and physical properties of the near-surface rocks of Mesita de Los Alamos, Los Alamos County, New Mexico: U.S. Geological Survey open-File Report 67-180, $32 \mathrm{p}$.

Geology, Geophysics.

513 . 1967, Record of water-supp1y we11 PM-3, Los Alamos, New Mexico: U.S. Geological Survey Open-File Report 67-181, $22 \mathrm{p}$. Geology, Geochemistry and geothermometry, Hydrology, Tabulated data.

514 . 1971, Plutonium in stream channel alluvium in the Los Alamos area, New Mexico: Los Alamos Scientific Laboratory Informal Report LA-4561, $7 \mathrm{p}$. Geochemistry and geothermometry, Hydrology, Tabulated data.

515 . 1973, Geology of the Jemez Plateau west of Valles Caldera: Los Alamos Scientific Laboratory Informal Report LA-5124-MS, $13 \mathrm{p}$. Geology, Tabulated data. 
516 .

1973, Regional survey of tritium in surface and ground water in the Los Alamos area, New Mexico, August 1966 through May 1969: Los Alamos Scientific Laboratory Informal Report LA-5234-MS, 8 p. Geochemistry and geothermometry, Hydrology, Tabulated data.

517 . 1973, Underground movement of tritium from solid waste storage shafts: Los Alamos Scientific Laboratory Informal Report LA-5286-MS, 7 p. Geology, Geochemistry and geothermometry, Hydrology, Tabulated data.

518 . 1974, Dispersion and movement of tritium in a shallow aquifer in Mortandad Canyon at the Los Alamos Scientific Laboratory: Los Alamos Scientific Laboratory Informal Report LA-5716-MS, $10 \mathrm{p}$.

Geology, Geochemistry and geothermometry, Hydrology, Tabulated data.

519.

1974, Storm runoff and transport of radionuclides in DP Canyon, Los Alamos County, New Mexico: Los Alamos Scientific Laboratory LA-5744, 9 p. Geochemistry and geothermometry, Hydrology, Tabulated data.

520 .

1975, Geohydrology of Pajarito Plateau with references to quality of water, 1949-1972: Los Alamos Scientific Laboratory Informal Report, 344 p. Geology, Geochemistry and geothermometry, Hydrology, Tabulated data.

521 . 1975, Water supply at Los Alamos during 1974: Los Alamos Scientific Laboratory Informal Report LA-5998-MS, $20 \mathrm{p}$. Hydrology, Tabulated data. 
522 . 1976, Water supply at Los Alamos during 1975: Los Alamos Scientific Laboratory Progress Report LA-6461-PR, $27 \mathrm{p}$.

Hydrology, Tabulated data.

523 .

1977, Hydrologic characteristics of the Los Alamos well field, with reference to the occurrence of arsenic in well LA-6: Los Alamos Scientific Laboratory Informal Report LA-7012-MS, 63 p.

Geology, Geochemistry and geothermometry, Hydrology, Tabulated data.

524 .

1977 , Water supply at Los Alamos during 1976: Los Alamos Scientific Laboratory Progress Report LA-6814-PR, $28 \mathrm{p}$.

Hydrology, Tabulated data.

525 . 1978, Water supply at Los Alamos during 1977: Los Alamos Scientific Laboratory Informal Report LA-7436-MS, $38 \mathrm{p}$.

Hydrology, Tabulated data.

526 . 1979, Water supply at Los Alamos during 1978: Los A1amos Scientific Laboratory Progress Report LA-8074-PR, $46 \mathrm{p}$. Hydrology, Tabulated data.

527 . 1980, Water supply at Los Alamos during 1979: Los A1amos Scientific Laboratory Progress Report LA-8504-PR, $44 \mathrm{p}$.

Hydrology, Tabulated data.

528 . 1984 , Hydrologic characteristics of the main aquifer in the Los Alamos area, Development of ground water supplies: Los Alamos National Laboratory LA-9957-MS, $44 \mathrm{p}$.

Geology, Geothermal, Hydrology, Tabulated data. 
529. Purtymun, W. D., and Adams, W. H., 1980, Geohydrology of Bandelier National Monument, New Mexico: Los Alamos

Scientific Laboratory Informal Report LA-8461-MS, 25 p. Geology, Geochemistry and geothermometry, Hydrology, Tabulated data.

530. Purtymun, W. D., and Cooper, J. B., 1969, Development of ground-water supplies on the Pajarito Plateau, Los Alamos County, New Mexico, in Geological Survey Research 1969, Chapter B: U.S. Geological Survey Professional

Paper 650-B, p. B149-B153.

Geology, Geochemistry and geothermometry, Hydrology, Tabulated data.

531. Purtymun, W. D., and Herceg, J. E., 1972, Summary of Los Alamos municipal wel1-field characteristics, 1947-1971: Los Alamos Scientific Laboratory LA-5040-MS, 69 p. Hydrology, Tabulated data.

532 . 1972, Water supply at Los Alamos during 1971: Los Alamos Scientific Laboratory LA-5039-MS, 29 p. Hydrology, Tabulated data.

533 . 1973, Water supply at Los Alamos during 1972: Los Alamos Scientific Laboratory LA-5296-MS, 37 p. Hydrology, Tabulated data.

534 . 1974, Water supply at Los Alamos during 1973: Los Alamos Scientific Laboratory Informal Report LA-5636-MS, $30 \mathrm{p}$. Hydrology, Tabulated data.

535. Purtymun, W. D.,, and Johansen, Steven, 1974, Genera1 geohydrology of the Pajarito Plateau, in Guidebook of Ghost Ranch: New Mexico Geological Society, 25 th Field Conference, p. 347-349.

Geology, Hydrology. 
536. Purtymun, W. D., and Jordon, H. S., 1973, Seismic program of the Los Alamos Scientific Laboratory: Los Alamos Scientific Laboratory Informa1 Report LA-5386-MS, 14 p. Geophysics.

537. Purtymun, W. D., and Kennedy, W. R., 1966, Distribution of moisture and radioactivity in the soil and tuff at the contaminated waste pit near Technical Area 21 , Los Alamos, New Mexico: U.S. Geological Survey Open-File Report 66-106, 46 p.

Geology, Geochemistry and geothermometry, Hydrology, Tabulated data.

538 . 1970, Geology and hydrology of Mesita Del Buey: Los Alamos Scientific Laboratory LA-4660, 12 p.

Geothermal, Geochemistry and geothermometry, Hydrology, Tabulated data.

539. Purtymun, W. D., and Maes, Max, 1981, Water supply at Los Alamos during 1980: Los Alamos Scientific Laboratory Progress Report LA-8977-PR, 34 p. Hydrology, Tabulated data.

540. Purtymun, W. D., Adams, W. H., and Owens, J. W., 1975 , Water quality in the vicinity of Fenton Hill Site, 1974: Los Alamos Scientific Laboratory LA-6093, 16 p. Geothermal, Geochemistry and geothermometry, Hydrology, Tabulated data.

541. Purtymun, W. D., Adams, W. H., and Stoker, A. K., 1978, Water quality in the vicinity of Fenton Hill Site, 1976: Los Alamos Scientific Laboratory Informal Report LA-7307-MS, $17 \mathrm{p}$.

Geothermal, Geochemistry and geothermometry, Hydrology, Tabulated data.

542. Purtymun, W. D., Becker, N. M., and Maes, Max, 1983, Water supply at Los Alamos during 1981: Los Alamos National Laboratory Progress Report LA-9734-PR, 46 p. Geochemistry and geothermometry, Hydrology, Tabulated data. 
543 . 1984, Water supply at Los Alamos during 1982: Los Alamos National Laboratory Progress Report LA-9896-PR, $46 \mathrm{p}$. Geochemistry and geothermometry, Hydrology, Tabulated data.

544. Purtymun, W. D., Ferenbaugh, R. W., and Adams, W. H., 1981 , Water quality in the vicinity of Fenton Hill, 1980: Los Alamos Scientific Laboratory Progress Report LA-9007-PR, $16 \mathrm{p}$.

Geothermal, Geochemistry and geothermometry, Hydrology, Tabulated data.

545. Purtymun, W. D., Hansen, W. R., and Peters, R. J., 1983, Radiochemical quality of water in the shallow aquifer in Mortandad Canyon, 1967-1978: Los Alamos National Laboratory LA-9675-MS, 18 p.

Geochemistry and geothermometry, Hydrology, Tabulated data.

546. Purtymun, W. D., Peters, R. J., and Owens, J. W., 1980 , Geohydrology of White Rock Canyon of the Rio Grande from otowi to Frijoles Canyon: Los Alamos Scientific Laboratory LA-8635-MS, $15 \mathrm{p}$.

Geology, Geochemistry and geothermometry, Hydrology, Tabulated data.

547. Purtymun, W. D., Peters, R. J., and Stoker, A. K., 1980 , Radioactivity in soils and sediments in and adjacent to the Los Alamos area, 1974-1977: Los Alamos Scientific Laboratory Informa1 Report LA-8234-MS, 17 p. Geology, Geochemistry and geothermometry, Hydrology, Tabulated data.

548. Purtymun, W. D., West, F. G., and Adams, W. H., 1974 , Preliminary study of the quality of water in the drainage area of the Jemez River and Rio Guadalupe: Los Alamos Scientific Laboratory Informal Report LA-5595-MS, 26 p. Geochemistry and geothermometry, Hydrology, Tabulated data. 
549. Purtymun, W. D., West, F. G., and Pettitt, R. A., 1974 , Geology of geothermal test hole GT-2, Fenton Hill Site, Ju1y 1974: Los Alamos Scientific Laboratory Informal Report LA-5780-MS, 15 p.

Geology, Geotherma1, Geochemistry and geothermometry, Hydrology, Geophysics, Tabulated data.

550. Purtymun, W. D., and others, 1974, Air volume and energy transfer through test holes and atmospheric pressure effects on the main aquifer: Los Alamos Scientific Laboratory Informal Report LA-5725-MS, 14 p. Geology, Hydrology, Geophysics, Tabulated data.

551 . 1976, Water quality in the vicinity of Fenton Hill Site, 1975: Los Alamos Scientific Laboratory Informal Report LA-6511-MS, 21 p.

Geothermal, Geochemistry and geothermometry, Hydrology, Tabulated data.

552 1977 , Water quality in the vicinity of Fenton Hill Site, 1977: Los Alamos Scientific Laboratory Progress Report LA-7468-PR, 21 p.

Geothermal, Geochemistry and geothermometry, Hydrology, Tabulated data.

553 1980, Water quality in the vicinity of Fenton Hill Site, 1978: Los Alamos Scientific Laboratory Progress Report LA-8217-PR, $21 \mathrm{p}$.

Geotherma1, Geochemistry and geothermometry, Hydrology, Tabulated data.

554. 1980, Water quality in the vicinity of Fenton Hill, 1979: Los Alamos Scientific Laboratory Progress Report LA-8424-PR, $21 \mathrm{p}$.

Geology, Geothermal, Geochemistry and geothermometry, Hydrology, Tabulated data.

555 . 1983, Water quality in the vicinity of Fenton Hi11, 1981 and 1982: Los Alamos National Laboratory Progress Report LA-9854-PR, $30 \mathrm{p}$.

Geochemistry and geothermometry, Hydrology, Tabulated data. 
556. Rainwater, F. H., and Thatcher, L. L., 1960, Methods for collection and analysis of water samples: U.S. Geological Survey Water-Supp1y Paper $1454,301 \mathrm{p}$.

Geochemistry and geothermometry, Hydrology.

557. Ramberg, I. B., and Smithson, S. B., 1975, Gridded fau1t patterns in a late Cenozoic and a Paleozoic continental rift: Geology, v. 3, no. 4, p. 201-205.

Geology.

558. Ramberg, I. B., Cook, F. A., and Smithson, S. B., 1978 , Structure of the Rio Grande Rift in southern New Mexico and west Texas based on gravity interpretation:

Geological Society of America Bulletin, v. 89, no. 1, p. 107-123.

Geology, Geophysics, Tabulated data.

559. Ramey, H. J., Jr., and Kruger, Pau1, eds., 1980, Proceedings, $6 \mathrm{th}$ workshop, geothermal reservoir engineering, December 16-18, 1980: Stanford, Calif., Stanford University SPG-TR-50, $383 \mathrm{p}$.

Geothermal, Modeling methods and background, Modeling applications, Collected technical articles.

560. Rapport, Amy, 1982, FORTRAN program to compute chemica1 geothermometers for geothermal fluids: U.S. Geological Survey Open-File Report 82-308, 25 p.

Geothermal, Geochemistry and geothermometry, Modeling applications, Modeling evaluation and documentation, Tabulated data.

561. Rea, K. H., 1977 , Environmenta1 investigations associated with the LASL hot dry rock geothermal energy development project: Los Alamos Scientific Laboratory Report LA-6972, $23 \mathrm{p}$.

Geology, Geotherma1, Geochemistry and geothermometry, Hydrology, Ecology, Tabulated data. 
562. Rea, K. H., and Gutschick, V., 1978, Environmental assessment of dissolved gasses in LASL's hot dry geothermal source demonstration project: Geothermal Resources Council Transactions, v. 2, p. 249-252. Geothermal, Geochemistry and geothermometry, Geophysics.

563. Reagan, A. B., 1903, Age of the lavas of the plateau region: American Geologist, v. 32, p. 170-177. Geology.

564 . 1903, Geology of the Jemez-Albuquerque region, New Mexico: American Geologist, v. 31, no. 2, p. 67-111. Geology, Geothermal, Geochemistry and geothermometry, Hydrology, Tabulated data.

565 . 1912 , Mineral resources of the Jemez-Albuquerque region: Mineral World, v. 36, p. 23 . Geology.

566. Reed, M. J., 1977, Geochemical comparison of deep geothermal waters in North America [abs.]: Geological Society of America Program with Abstracts, v. 9, no. 7 , p. 1138 . Geothermal, Geochemistry and geothermometry, Hydrology.

567. Reeves, H. V., Jr., 1967, New Mexico's big share of the National Park System, in Mosaic of New Mexico's scenery, rocks and history, 2nd edition: New Mexico Bureau of Mines and Mineral Resources Scenic Trips of the Geologic Past 8, p. 75-92. Geology, Ecology.

568. Reilinger, R. E., and York, J. E., 1979, Relative crustal subsidence from leveling data in a seismically active part of the Rio Grande Rift, New Mexico: Geology, v. 7 , no. 3, p. 139-143.

Geology, Geophysics. 
569. Reiter, Marsha11, and Hartman, Haro1d, 1971 , A new steady-state method for determining thermal conductivity: Journal of Geophysical Research, v. 76, no. 29, p. 7047-7051.

Geothermal, Geophysics, Tabulated data.

570. Reiter, Marsha11, Shaerer, C., and Edwards, C. L., 1978 , Geothermal anomalies along the Rio Grande Rift in New Mexico: Geology, v. 6, p. 85-88.

Geothermal.

571. Reiter, Marsha11, and others, 1975, Terrestrial heat flow along the Rio Grande Rift, New Mexico and southern Colorado: Geological Society of America Bulletin, v. 86, no. 6, p. 81l-818. Geology, Geothermal.

572 . 1976, Subsurface temperature data in Jemez Mountains, New Mexico: New Mexico Bureau of Mines and Mineral Resources Circular $151,16 \mathrm{p}$. Geothermal, Geophysics, Tabulated data.

573. Renick, B. C., 1926, Geology and artesian water prospects in the San Jose-Rio Puerco Valley in Sandoval County, in Seventh biennial report, State Engineer of New Mexico, 1925-1926: New Mexico State Engineer, p. 61-75. Geology, Hydrology.

574 . 1931, Geology and ground water resources of western Sandoval County, New Mexico: U.S. Geological Survey WaterSupply Paper 620, $117 \mathrm{p}$. Geology, Hydrology, Tabulated data.

575. Republic Geothermal, Inc., 1980, Proposal for producing well hydrologic fracture stimulation treatment, Baca project area - Geothermal reservoir well stimulation program: consultant report for U.S. Department of Energy under contract No. DE-AC32-79ALl0563, $94 \mathrm{p}$.

Geothermal, Hydrology, Geophysics, Tabulated data. 
576. Rice, L. F., and Garg, S. K., 1981, Interference test data and analysis for Baca Wells in the Redondo Creek area: System, Science and Software Reprint SSS-R-82-5325, consultant report for Union Geothermal of New Mexico (see Union 0il Company of California, Union Geothermal Division, Los Angeles, California). Geothermal, Geophysics.

577. Riecker, R. E., ed., 1979, Rio Grande Rift - Tectonics and magmatism (1979): American Geophysical Union, 438 p. Geology, Geochemistry and geothermometry, Geophysics, Tabulated data.

578. Rocky Mountain Geochemical Corporation, 1974, Mercury analysis - 1974 gradient holes: consultant report for Union 0il Company of California, Union Geothermal Division, Los Angeles, California, 2 p. Geochemistry and geothermometry, Hydrology, Tabulated data.

579. Roegiers, J. C., and Brown, D. W., 1974, Geothermal energy, A new application of rock mechanics: International Society of Rock Mechanics, v. 2, no. 3, part A, P. 674-680. Geology, Geothermal, Geophysics.

580. Roegiers, J. C., and Thill, R. E., 1976, Rock characterization at a geothermal site: Seventeenth U.S. symposium on rock mechanics, Snowbird, Utah, p. $505.1-505.6$. Geology, Geothermal.

581. Rogers Engineering Company, Inc., 1974, Geothermal power plant feasibility report: consultant report for Union 0il Company of California, Union Geothermal Division, Los Angeles, California, $108 \mathrm{p}$. Geothermal, Geophysics, Tabulated data.

582. Romer, A. S., 1960, The vertebrate fauna of the New Mexico Permian, in Guidebook of Rio Chama Country: New Mexico Geological Society, 11 th Field Conference, p. 48-54. Geology, Ecology. 
583. Ross, C. S., 1931, Valles Mountain, Volcanic center of New Mexico [abs.]: American Geophysical Union Transactions, $12 \mathrm{th}$ Annual Meeting, June 1931, p. 185-186. Geology, Geothermal.

584 .

1938, Vailes Volcano, New Mexico [abs.]: Washington Academy of Science Journa1, v. 28, no. 9, p. 417 . Geology, Geothermal.

585 . 1962, Valle Grande: New Mexico Magazine, v. 40, no. 1, p. 8-11. Geology, Geotherma1.

586. Ross, C. S., Smith, R. L., and Bailey, R. A., 1961, Outline of geology of the Jemez Mountains, New Mexico, in Guidebook of Albuquerque Country: New Mexico Geological Society, 12 th Field Conference, p. 139-143. Geology.

587. Rubin, Hille1, 1977, Thermal convection in a cavernous aquifer: Water Resources Research, v. 3, no. 11, p. 34-40. Geotherma1, Hydrology, Geophysics.

588 . 1981 , Thermal convection in a nonhomogeneous aquifer: Journal of Hydrology, v. 50, p. 317-331. Geology, Geotherma1, Hydrology, Geophysics.

589. Sageev, A., and others, 1980, The effect of temperature on the absolute permeability to distilled water of unconsolidated sand cores, in Proceedings, 6 th workshop, geothermal reservoir engineering, December 16-18, 1980: Stanford, Calif., Stanford University SPG-TR-50, p. 297-302.

Geothermal, Geophysics.

590. Sanford, A. R., Alplekin, Omer, and Toppozada, T. R., 1973, Use of reflection phases on microearthquake seismograms to map unusual discontinuity beneath the Rio Grande Rift: Bulletin of the Seismological Society of America, v. 63, no. 6, p. 2021-2034.

Geology, Geophysics, Tabulated data. 
591. Sanford, A. R., 01sen, K. H., and Jaksha, L. H., 1979, Seismicity of the Rio Grande Rift, in Rieker, R. E., ed., Rio Grande Rift tectonics and magnetism: Washington, D.C., American Geophysical Union, p. 145-168. Geology, Geophysics.

592. Sanford, A. R., and others, 1972 , Seismicity of the Rio Grande Rift in New Mexico: New Mexico Bureau of Mines and Mineral Resources Circular 120,19 p. Geology, Geophysics.

593. Sanyal, S. K., We11s, L. E., and Bickham, R. E., 1979 , Geothermal we11 log interpretation, Midterm report: Los Alamos Scientific Laboratory Report LA-7693, 178 p. Geothermal, Geophysics.

594. Sass, J. H., Lachenbruch, A. H., and Monroe, R. J., 1971 , Thermal conductivity of rocks from measurements of fragments and its application to heat-flow determinations: Journal of Geophysical Research, v. 76 , no. 14, p. $3391-3401$. Geotherma1, Geophysics, Tabulated data.

595. Sass, J. H., and others, 1971 , Heat flow in the Western United States: Journal of Geophysical Research, v. 76 , no. 26, p. 6376-6413. Geology, Geotherma1, Geophysics, Tabulated data.

596. Saucier, A. E., 1974, Stratigraphy and uranium potential of the Burro Canyon formation in the southern Chama Basin, New Mexico, in Guidebook of Ghost Ranch: New Mexico Geological Society, 25th Field Conference, p. 211-217. Geology.

597. Savage, W. U., E1y, R. W., and Tocher, D., 1977, Review of the Los Alamos seismic monitoring program in relation to the hot dry rock geothermal project: report for Los Alamos Scientific Laboratory by Woodward-Clyde Consultants, San Francisco, California, 30 p. Geology, Geothermal, Geophysics. 
598. Schiager, K. J., and Apt, K. E., 1974, Environmental surveillance at Los Alamos during 1973: Los Alamos Scientific Laboratory Report LA-5586, 57 p.

Geology, Hydrology, Ecology, Tabulated data.

599. Schubert, Gera1d, and Straus, J. M., 1981, Thermodynamic properties for the convection of steam-water-co2 mixtures: American Journal of Science, v. 281, no. 3, p. 318-334.

Geothermal, Geochemistry and geothermometry, Geophysics, Tabulated data.

600. Schwartz, G. M., 1959, Hydrothermal alteration: Economic Geology, v. 54, no. 2, p. 161-183.

Geology, Geothermal, Geochemistry and geothermometry, Hydrology, Geophysics, Tabulated data.

601. Sears, R. S., 1953, Geology of the area between Canjilon Mesa and Abiquiu, Rio Arriba County, New Mexico: Albuquerque, N. Mex., University of New Mexico, unpublished M.S. thesis. Geology.

602. Segar, R. L., 1974, Quantitative gravity interpretation, Valles Caldera area, New Mexico: Los Angeles, Calif., Union oil Company of California, Union Geothermal Division, $12 \mathrm{p}$.

Geotherma1, Geophysics.

603. Semprini, Lewis, and Kruger, Paul, 1980, Radon transect studies in vapor-and liquid-dominated geothermal reservoirs, in Proceedings, $6 \mathrm{th}$ workshop, Geothermal reservoir engineering, December 16-18, 1980: Stanford, Calif., Stanford University SPG-TR-50, p. 344-350.

Geothermal, Geochemistry and geothermometry, Tabulated data. 
604. Sestini, G., 1970, Superheating of geothermal steam, in Proceedings of the United Nations symposium on the development and utilization of geothermal resources, Pisa, Italy, September 22 - 0ctober 1, 1970: Geothermics International Journal of Geothermal Research, Special Issue 2, part 1, p. 622-648.

Geothermal, Geophysics.

605. Shafer, B. A., Marron, J. K., and Teilborg, J. R., 1979, Water supply outlook for Colorado and New Mexico and federal-state-private cooperative snow surveys as of March 1, 1979: U.S. Department of Agriculture and Soil Conservation Service, 2 sheets. Hydrology, Tabulated data.

606. Sherwood, P. B., and others, 1980, Executive summaries of reports leading to the construction of the Baca geothermal demonstration project: prepared by WESTEC Services, Inc. for Union Geothermal Company of New Mexico and Public Service Company of New Mexico, U.S. Department of Energy Contract ET-78-F-03-1717, 328 p. Geology, Geothermal, Geochemistry and geothermometry, Hydrology, Geophysics, Review articles, Collected technical articles, Tabulated data.

607. Sheu, J. P., Torrence, K. E., and Turcotte, D. L., 1980, 0n the structure of two-phase hydrothermal flows in permeable media: Journal of Geophysical Research, v. 84 , no. B 14, p. 7524-7532. Geothermal, Hydrology, Geophysics.

608. Sibbitt, W. L., 1979, Preliminary measurements of thermal conductivity of rocks from the LASL geothermal test holes GT-1 and GT-2: Los Alamos Scientific Laboratory Informal Report LA-6199-MS, 8 p.

Geology, Geothermal, Geochemistry and geothermometry, Tabulated data. 
609. Sibbitt, W. L., Dodson, J. G., and Tester, J.W., 1979, Thermal conductivity of crystalline rocks associated with energy extraction from hot dry rock geothermal systems: Journal of Geophysical Research, v. 84, no. 3 , p. $1117-1124$.

Geology, Geochemistry and geothermometry, Tabulated data.

610. Siciliano, C. L. B., ed., and Kaufman, E. L., compiler, 1979, Environmenta 1 analysis of the Fenton Hil1 hot dry rock geothermal site: Los Alamos Scientific Laboratory LA-7830, $57 \mathrm{p}$.

Geotherma1, Ecology

611. Siemers, C. T., Ca11ender, J.F., and others, 1975, Fie1d trips to central New Mexico: American Association of Petroleum Geologists, Rocky Mountain Section, Society of Economic Paleontologists and Mineralogists, June 1-4, 1975 , Albuquerque, New Mexico, 169 p.

Geology, Geothermal, Geochemistry and geothermometry, Hydrology, Collected technical articles, Tabulated data.

612. Siemers, C. T., King, N. R., and Mannhard, G. W., 1975 , Upper Jurassic and Cretaceous stratigraphy and sedimentology - eastern San Juan Basin, New Mexico, in Field trips to central New Mexico: American Association of Petroleum Geologists, Rocky Mountain Section, Society of Economic Paleontologists and Mineralogists, June 1-4, 1975 , A1buquerque, New Mexico, p. 1-102.

Geology, Geothermal, Geochemistry and geothermometry, Hydrology, Tabulated data.

613. Siemers, C. T., Woodward, L. A., and Callender, J.F., eds., 1974, Guidebook of Ghost Ranch: New Mexico Geological Society, $25 \mathrm{th}$ Field Conference, 404 p.

Geology, Geotherma1, Hydrology, Collected technical articles, Tabulated data.

614. Siems, P. L., 1964, Correlation of Tertiary strata in mountain basins, southern Colorado and northern New Mexico: Mountain Geologist, v. 1, p. 161-180.

Geology. 
615. Simmons, Gene, and Eddy, Andrea, 1976, Microcracks in GT-2 core [abs.]: American Geophysical Union Transactions, v. 57 , no. 4, p. 353 .

Geology, Geothermal, Geochemistry and geothermometry, Geophysics.

616. Slack, P. B., and Campbe11, J. A., 1976, Structural geology of the Rio Puerco fault zone and its relationship to central New Mexico tectonics, in Tectonics and mineral resources of Southwestern North America, 1976: New Mexico Geological Society Special Publication 6, p. 46-52. Geology, Geophysics.

617. Slemmons, D. B., 1975, Fault activity and seismicity near the Los Alamos Scientific Laboratory geothermal test site, Jemez Mountains, New Mexico: Los Alamos Scientific Laboratory Informal Report LA-5911-MS, 26 p. Geothermal, Geophysics.

618. Slodowski, T. R., 1976, Geothermal geology of the Redondo Creek area, Baca location, New Mexico: Los Angeles, Calif., Union $0 i l$ Company of California, Union Geothermal Division, $4 \mathrm{p}$. and 10 plates. Geology, Geothermal.

619. 1977, Geological resume of the Valles Caldera: Los Angeles, Calif., Union $0 i 1$ Company of California, Union Geothermal Division, 11 p. and 4 plates. Geology, Geothermal, Hydrology, Tabulated data.

620. Smith, C. T., 1951, Problems of Jurassic stratigraphy of the Colorado plateau and adjoining regions, in Guidebook of the south and west sides of the San Juan Basin, New Mexico and Arizona: New Mexico Geological Society, 2nd Field Conference, p. 99-102.

Geology.

621 . 1957 , Entrance road $10 g$, Albuquerque to Durango, in Guidebook of Southwestern San Juan Mountains (Colorado): New Mexico Geological Society, $8 \mathrm{th}$ Field Conference, p. 27-37.

Geology. 
622. Smith, C. T., and Mueh1berger, W. R., 1960, Road 1og, Taos to Chama via 0jo Caliente, E1 Rito, Canjilon, Cebolla, Cumbres Pass, and return to Chama, in Guidebook of Rio Chama Country: New Mexico Geological Society, 11th Field Conference, p. 11-24.

Geology.

623. Smith, C. T., Budding, A. J., and Pitrat, C. W., 1961 , Geology of the south-eastern part of the Chama Basin: New Mexico State Bureau of Mines and Mineral Resources Bu1letin 75, 57 p., 8 maps.

Geology.

624. Smith, C. T., and others, 1960, Road log, Chama to Parkview and return to Chama via Lumberton, Dulce, Yegua Canyon, E1 Vado and Parkview, in Guidebook of Rio Chama Country: New Mexico Geological Society, 11 th Field Conference, p. 25-34. Geology •

625 . 1960, Road 1 og, Chama to vicinity of Cuba via Ghost Ranch, Coyote and Regina, in Guidebook of Rio Chama Country: New Mexico Geological Society, $11 \mathrm{th}$ Field Conference, p. 35-44. Geology.

626. Smith, E. I., 1967, Criteria for the determination of flow direction in rocks: Albuquerque, N. Mex., University of New Mexico, unpublished M.S. thesis, 118 p. Geology, Geophysics.

627. Smith, E. I., and E1ston, W. E., 1967, Determination of flow direction of rhyolitic ash-flow tuffs, and andesitic lavas from fluidal textures [abs.], in Program, Geological Society of America meeting in New Orleans, 1967: Geological Society of America, p. 207. Geology.

628. Smith, J. L., Isse1hordt, C. F., and Mat1ick, J. S., 1978, Summary of 1977 geothermal drilling, Western United States: Geothermal Energy, v. 6, no. 5, p. 11-19. Geothermal. 
629. Smith, M. C., 1973, Geothermal energy: Los Alamos

Scientific Laboratory Informal Report LA-5289-MS, 31 p. Geothermal.

630 .

1974, Geothermal energy: article submitted to the

Subcomittee on Energy, Committee on Science and

Astronautics and U.S. House of Representatives: Los

Alamos Scientific Laboratory LA-UR-74-252, 9 p.

Geothermal.

631 .

1974 , Geothermal power: article submitted to the American Institute of Physics, American Physical Society Meeting, February 7, 1974: Los Alamos Scientific

Laboratory LA-UR-74-233, 11 p.

Geothermal, Hydrology, Geophysics.

632 .

1976, The LASL dry hot rock concept [abs.]: American Geophysical Union Transactions, v. 57, no. 4, p. 349. Geology, Hydrology.

633. Smith, M. C., Brown, D. W., and Pettitt, R. A., 1975, Los Alamos dry geothermal source demonstration project: Los Alamos Scientific Laboratory Mini-review 75-1, 4 p. Geology, Geothermal, Hydrology.

634. Smith, M. C., and others, 1975, The LASL dry hot rock geothermal project (LASL Group Q-22): Geothermics, v. 4, no. $1-4$, p. 27-39.

Geothermal.

635. Smith, R. L., 1960, Ash flows: Geological Society of America Bulletin, v. 71, no. 6, p. 795-842. Geology.

636. Smith, R. L., and Bailey, R. A., 1967, Stratigraphy, structure and volcanic evolution of the Jemez Mountains, New Mexico [abs.]: Geological Society of America, Rocky Mountain Section $12 t h$ Annual Meeting, p. 63-64.

Geology. 
637 . 1967, The Bandelier tuff, A study of ash-flow eruption cycles from zoned magma chambers: Bulletin of Volcanology, v. 29, p. 83-103.

Geology, Geophysics.

638 . 1968 , Resurgent cauldrons, in Studies in volcanology, A memoir in honor of Howel Williams: Geological Society of America Memoir 116, p. 613-662.

Geology, Geophysics.

639. Smith, R. L., and Shaw, H. R., 1973, Volcanic rocks as geologic guides to geothermal exploration and evaluation [abs.]: American Geophysical Union Transactions, v. 54 , no. 11, p. 1213 .

Geology, Geothermal.

640 .

1975, Igneous-related geothermal systems, in Assessment of geothermal resources of the United States-1975: U.S. Geological Survey Circular 726, p. 58-83.

Geothermal, Collected technical articles.

641. Smith, R. L., Bailey, R. A., and Ross, C. S., 1961, Structural evolution of the Valles Caldera, New Mexico, and its bearing on the emplacement of ring dikes, in Short Papers in the Geologic and Hydrologic Sciences, articles 293-435: U.S. Geological Survey Professional Paper 424-D, p. D145-D149.

Geothermal, Geophysics.

642 .

1970, Geologic map of the Jemez Mountains, New

Mexico: U.S. Geological Survey Miscellaneous Geologic Investigations Map I-571, scale 1:24,000, 1 sheet. Geology.

643. Somerton, W. H., 1974, Deformation moduli of water-bearing formations at elevated temperatures: Davis, Calif., California Water Resources Center, Contribution No. $146,66 \mathrm{p}$. Geothermal, Hydrology, Geophysics, Tabulated data. 
644. Sorensen, E. F., 1977, Water use by categories in New Mexico counties and river basins, and irrigated and dry cropland acreage in 1975: New Mexico State Engineer office Technical Report 41,34 p. Hydrology, Tabulated data.

645 . 1982 , Water use by categories in New Mexico counties and river basins, and irrigated acreage in 1980: New Mexico State Engineer Office Technical Report 44, 51 p. Hydrology, Tabulated data.

646. Sorey, M. L., 1971 , Measurement of vertical ground-water velocity from temperature profiles in wells: Water Resources Research, v. 7, no. 4, p. 963-969. Geothermal, Hydrology.

647 . 1978 , Numerical modeling of liquid geothermal systems: U.S. Geological Survey Professional Paper $1044-\mathrm{D}, 25 \mathrm{p}$.

Geothermal, Modeling methods and background.

648 . 1980 , Basic components of reservoir evaluation, Notes for introductory course in geothermal reservoir engineering: Geothermal Resource Council publication, 32 p.

Geothermal, Geochemistry and geothermometry, Hydrology, Modeling methods and background, Textbook.

649. Sorey, M. L., Grant, M. A., and Bradford, Elizabeth, 1980, Nonlinear effects in two-phase flow to wells in geothermal reservoirs: Water Resources Research, v. 16 , no. 4, p. 767-777.

Geothermal, Modeling methods and background.

650. Southwest Environmental Research and Development Corporation, 1974, The biota of Redondo Creek Canyon, Sandoval County, New Mexico, with emphasis on big game species and rare, endangered or threatened species: consultant report for Union 0il Company of California, Union Geothermal Division, Los Angeles, California, 71 p. Hydrology, Ecology, Tabulated data. 
651. Spence, William, Gross, R. S., and Jaksha, L. H., 1979 , $P$-wave velocity structure beneath the central Rio Grande Rift [abs.]: American Geophysical Union Transactions, v. 60 , no. 46, p. 953-954. Geology, Geophysics.

652. Spence, William, and others, 1982, P-wave velocity structure beneath the Jemez Lineament, New Mexico [abs.]: American Geophysical Union Transactions, v. 63, no. 45, p. $1117-1118$. Geology, Geophysics.

653. Spiegel, Z. E., 1957, Review of data available concerning water supplies near Cuba, Sandoval County, New Mexico: New Mexico State Engineer office open-file report, 5 p. Hydrology.

654 1961 , Late Cenozoic sediments of the lower Jemez River region, in Guidebook of Albuquerque Country: New Mexico Geological Society, 12 th Field Conference, p. $132-138$. Geology.

655 . 1961 , Domestic water supply for Santo Domingo (Pueblo), New Mexico: consultant report to U.S. Public Health Service, 8 p.

Hydrology.

656 .

1962 , Domestic water supply for Jemez (Sandoval County), New Mexico: consultant report to U.S. Public Health Service, 9 p. Hydrology.

657 . 1971 , Report on an alternate site for the Jemez weli, Española, New Mexico: consultant report to the City of Espanola, 4 p. and 2 appendices. Geology, Hydrology.

658. Stallman, R. W., 1960, Notes on the use of temperature data for computing ground-water velocity: U.S. Geological Survey Ground-Water Notes, Hydraulics, no. 39,17 p. Geothermal, Hydrology. 
659. State of New Mexico District Court, 1981, Pueblo of Santa Ana v. New Mexico State Engineer and Union Geothermal Company - Answers of Union Geothermal Company of New Mexico to interrogatories submitted by the Pueblo of Santa Ana: State of New Mexico District Court No. $\mathrm{SCV}-80-249,39 \mathrm{p}$.

Geothermal, Hydrology, Tabulated data.

660. Stearns, C. E., 1943, Galisteo formation of north-central New Mexico: Journal of Geology, v. 51, no. 5, p. 301-319. Geology.

661. Stearns, H. T., 1948, Ground-water supplies for Los Alamos, New Mexico: consultant report to Black and Veatch, Denver, Colorado, for the U.S. Atomic Energy Commission, $32 \mathrm{p}$. Geology, Hydrology.

662 . 1952, Collapse versus explosive origin of Valles Caldera, Sandoval County, New Mexico [abs.]: Geological Society of America, v. 63, no. 12, part 2, p. 1371-1372. Geology, Geophysics.

663. Stearns, N. D., Stearns, H. T., and Waring, G. A., 1937, Thermal springs in the United States: U.S. Geological Survey Water-Supply Paper 679-B, 206 p. Geothermal, Geochemistry and geothermometry, Tabulated data.

664. Stearns-Roger, Inc., 1975, Preliminary ground-level hydrogen suifide concentration estimates, Baca Location No. 1, New Mexico: consultant report for Union 0il Company of California, Union Geothermal Division, Los Angeles, California, 19 p. Geothermal, Geochemistry and geothermometry, Tabulated data.

665 1975, Preliminary investigation, hydrogen sulfide background levels, Baca Location No. 1, New Mexico: consultant report for Union Oil Company of California, Union Geothermal Division, Los Angeles, California, 162 . Geothermal, Geochemistry and geothermometry, Tabulated data. 
666.

1975, Second progress report, meteorological and

hydrogen sulfide monitoring programs, Baca Location No. 1 , New Mexico: consultant report for Union 0il Company of

California, Union Geothermal Division, Los Angeles, California, 375 p.

Geothermal, Geochemistry and geothermometry, Tabulated data.

667. 1975, Third progress report, meteorological and hydrogen sulfide monitoring programs, Baca Location No. 1 , New Mexico: consultant report for Union 0il Company of California, Union Geothermal Division, Los Angeles, California, $375 \mathrm{p}$.

Geotherma1, Geochemistry and geothermometry, Tabulated data.

668 . 1976, Annual report, meteorological and air quality monitoring programs, Baca Location No. 1, New Mexico: consultant report for Union $0 i l$ Company of California, Union Geothermal Division, Los Angeles, California, 199 p. Geotherma1, Hydrology, Tabulated data.

669. Steven, T. A., and Epis, R. D., 1968, 01igocene volcanism in south-central Colorado, in Cenozoic volcanism in the southern Rocky Mountains: Colorado School of Mines Quarter1y, v. 64, no. 3, p. 241-258.

Geology.

670. Stormer, C. J., Jr., 1972, Ages and nature of volcanic activity on the southern High Plains, New Mexico and Colorado: Geological Society of America Bulletin, v. 83 , p. 2443-2448.

Geophysics.

671. Stoy, Michae1, 1981, Project threatens water supp1y: Letter to the editor, Albuquerque Journal, January $13,1981$. Geothermal, Review articles, Correspondence.

672. Sudo1, G. A., Harris, R. F., and Ramey, H. J. Jr., 1979 , Annotated research bibliography for geothermal reservoir engineering: Lawrence Berkeley Laboratory LBL-8664 GREMP-1, 150 p. Geotherma1, Bibliography. 
673. Summers, W. K., 1965, A preliminary report on New Mexico's geothermal energy resources: New Mexico Bureau of Mines and Mineral Resources Circular 80,41 p.

Geothermal, Geochemistry and geothermometry, Hydrology, Tabulated data.

674 .

1965, Chemical characteristics of New Mexico's thermal waters, A critique: New Mexico Bureau of Mines and Mineral Resources Circular 83, 27 p. Geothermal, Geochemistry and geothermometry, Tabulated data.

675 . 1966, Distribution and occurrence of New Mexico's thermal waters - A statistical summary [abs.], in Guidebook of Taos-Raton-Spanish Peaks Country ( Mexico and Colorado): New Mexico Geological Society, 17 th Field Conference, p. 122 .

Geology, Geothermal, Geochemistry and geothermometry.

676 . 1968, Geothermics--New Mexico's untapped resource: New Mexico Bureau of Mines and Mineral Resources Circular $98,9 \mathrm{p}$. Geothermal.

677 . 1968, Scientists in hot water: New Mexico Magazine, v. 46, no. 5, p. 17-19. Geology, Geothermal, Hydrology.

678. Summers, W. K., compiler, 1971 , Annotated and indexed bibliography of geothermal phenomena: New Mexico Bureau of Mines and Mineral Resources, 673 p. Geothermal, Bibliography.

679. Summers, W. K., 1972, Approximation of thermal gradient in southeastern New Mexico using bottom hole temperatures from electric logs: America Association of Petroleum Geologists Bulletin, v. 56, no. 10, p. 2072-2074. Geothermal, Geophysics, Tabulated data. 
680 .

1976, Catalog of thermal waters in New Mexico: New Mexico Bureau of Mines and Mineral Resources Hydrologic Report 4, $80 \mathrm{p}$.

Geothermal, Hydrology, Tabulated data.

681 .

n.d., Geothermal prospects in New Mexico: New Mexico Bureau of Mines and Mineral Resources, Preprint, 23 p. Geology, Geotherma1, Hydrology, Tabulated data.

682. Sun, Ming-Shan, and Baldwin, Brewster, 1958, Volcanic rocks of the Cienega area, Santa Fe County, New Mexico: New Mexico Bureau of Mines and Mineral Resources Bulletin 54 , $80 \mathrm{p}$.

Geology •

683. Swanberg, C. A., 1978, Chemistry, origin and potential of geothermal resources in southwestern New Mexico and southeastern Arizona, in Guidebook of Land of Cochise (Southeastern Arizona): New Mexico Geological Society, $29 \mathrm{th}$ Field Conference, p. 349-351.

Geothermal, Geochemistry and geothermometry, Tabulated data.

684 .

1979, Chemistry of thermal and non-thermal

groundwaters in the Rio Grande Rift and adjacent tectonic provinces, in Rio Grande Rift - Tectonics and Magmatism: American Geophysical Union, p. 279-287.

Geothermal, Geochemistry and geothermometry, Hydrology.

685 .

1980 , Chemistry, origin, and geothermal potential of thermal and non-thermal ground waters in New Mexico: U.S. Geological Survey open-file report (in press).

Geology, Geotherma1, Hydrology, Tabulated data.

686 .

1980 , The correlation among water chemistry,

regional heat flow, and the geothermal potential of the Western United States: U.S. Geological Survey open-file report (in press).

Geotherma1, Geochemistry and geothermometry, Hydrology, Tabulated data. 
687 . 1983 , Heat flow at the Valles Caldera, New Mexico [abs.]: Geological Society of America Abstracts with Programs, v. 15, no. 5, p. 381 .

Geology, Geothermal.

688. Swanberg, C. A., and Alexander, Shari, 1978, The use of the random ground water data from WATSTORE in geothermal exploration, An example from the Imperial Valley, California: Geothermal Resources Council Transactions, v. 2, p. 635-638.

Geothermal, Geochemistry and geothermometry, Tabulated data.

689.

1979 , Use of the water quality file WATSTORE in geothermal exploration, An example from the Imperial Valley, California: Geology, v. 7, p. 108-111.

Geothermal, Geochemistry and geothermometry, Hydrology.

690. Swanberg, C. A., and Morgan, Paul, 1979, The linear relation between temperatures based on the silica content of groundwater and regional heat flow - A new heat flow map of the United States: Pure and Applied Geophysics, v. 117 , nos. 1/2 (1978/79), p. 227-241.

Geothermal, Geochemistry and geothermometry.

691. Swanberg, C. A., and Stoyer, C. H., 1976, Regional water chemistry studies as a geothermal reconnaissance tool: American Geophysical Union Transactions, v. 57, no. 4, p. 353 .

Geothermal, Geochemistry and geothermometry.

692. Swanberg, C. A., and others, 1980, Geothermal resources of New Mexico: New Mexico Energy Institute map, 1 sheet. Geothermal.

693. Terra Tek, Inc., 1979, Final report test on Phippipine basalt and Baca-17 tuff geothermal well cores: consultant report for Union 0il Company of California, Union Geothermal Division, Los Angeles, California.

Geology, Geothermal, Hydrology. 
694. Tester, J. W., and A1bright, J. N., 1979, eds., Hot dry rock energy extraction field test, 75 days of operation of a prototype reservoir at Fenton Hill, segment 2 of phase 1: Los Alamos Scientific Laboratory Informal Report LA-7771-MS, $104 \mathrm{p}$.

Geology, Geothermal, Geochemistry and geothermometry, Hydrology, Tabulated data.

695. Theis, C. V., 1938, Ground water in the middle Rio Grande Valley, New Mexico, in Regional planning, Part VI - The Rio Grande joint investigation in the upper Rio Grande Basin in Colorado, New Mexico, and Texas, 1936-1937. Volume I: National Resources Committee, p. 268-291.

Hydrology.

696. 1950. Geologic background of water and water-supply problems at Los Alamos, New Mexico, in Meeting of Atomic Energy Commission, Waste Processing Committee at Los Alamos, New Mexico: U.S. Atomic Energy Technical Information Service, TID-460, p. 1-8. Hydrology.

697. Theis, C. V., and Conover, C. S., 1962, Pumping test in the Los Alamos Canyon well field near Los Alamos, New Mexico: U.S. Geological Survey Water-Supply Paper 1619-I, 24 p. Hydrology, Tabulated data.

698. Theis, C. V., and Taylor, G. C., Jr., 1938, Ground-water conditions in the middle Rio Grande Valley, New Mexico, in Twelfth and thirteenth biennial reports of the state Engineer of New Mexico: Santa Fe, N. Mex., New Mexico State Engineer, p. 263-271.

Hydrology, Tabulated data.

699. Titus, F. B., Jr., 1961, Ground-water geology of the Rio Grande trough in north-central New Mexico, with sections on the Jemez Caldera and the Lucero Uplift, in Guidebook of Albuquerque Country: New Mexico Geological Society, $12 \mathrm{th}$ Field Conference, p. 186-192. Geology, Hydrology.

700. Toronyi, R. M., 1974, Two-phase, two-dimensional simulation of a geothermal reservoir and the wellbore system: State College, Pa., Pennsylvania State University, unpublished Ph.D. dissertation.

Geothermal, Modeling methods and background. 
701. Towle, J. E., 1980, New evidence for magmatic intrusion beneath the Rio Grande Rift, New Mexico: Geological Society of America Bulletin, v. 91, Part 1, p.626-630. Geology, Geophysics.

702. Trainer, F. W., 1974, Geothermal waters in the Jemez Mountains volcanic region, north-central New Mexico [abs.]: Geological Society of America Abstracts with Programs, v. 6, no. 7, p. 991 .

Geothermal, Geochemistry and geothermometry, Hydrology.

703 .

1974, Ground water in the southwestern part of the Jemez Mountains volcanic region, New Mexico, in Guidebook of Ghost Ranch: New Mexico Geological Society, 25 th Field Conference, p. 337-345.

Geology, Geothermal, Geochemistry and geothermometry, Hydrology, Geophysics, Tabulated data.

704. 1975, Mixing of thermal and nonthermal waters in the margin of the Rio Grande Rift, Jemez Mountains, New Mexico, in Guidebook of Las Cruces Country: New Mexico Geological Society, 26th Field Conference, p. 213-218. Geothermal, Geochemistry and geothermometry, Hydrology, Tabulated data.

705 . 1978 , Geohydrologic data from the Jemez Mountains and vicinity, north-central New Mexico: U.S. Geological Survey Water-Resources Investigations 77-131, $146 \mathrm{p}$. Geothermal, Geochemistry and geothermometry, Hydrology, Geophysics, Tabulated data.

706. Trainer, F. W., and Lyford, F. P., 1979, Geothermal hydrology in the Rio Grande Rift, north-central New Mexico, in Guidebook of Santa Fe Country: New Mexico Geological Society, 30th Field Conference, p. 299-306. Geothermal, Hydrology, Tabulated data.

707. Trainer, F. W., and others, 1975, Guidebook to a field trip through part of the Rio Grande Valley and Jemez Mountains of northern New Mexico: prepared for the U.S. Geological Survey, Water Resources Division, District Chiefs' Conference, September 28-0ctober 3, 1975, 61 p. Geology, Geothermal. 
708. Trexler, D. T., Be11, E. J., and Roquemore, G. R., 1978 ,

Evaluation of lineament analysis as an exploration

technique for geothermal energy, western and central

Nevada: report to the Nevada Bureau of Mines and Geology, U.S. Department of Energy Contract EY-76-S-08-0671, 78 p. Geology, Geothermal, Geophysics.

709. Truesde11, A. H., 1975, Geotherm, A geothermometric computer program for hot-spring systems, in Proceedings, Second United Nations symposium on the development and use of geothermal resources, San Francisco, California, USA, May 20-29, 1975: U.S. Government Printing Office, v. 1, p. 831-836. Geochemistry and geothermometry, Modeling methods and background, Tabulated data.

710. Truesde11, A. H., and Fournier, R. 0., 1977, Procedure for estimating the temperature of a hot-water component in a mixed-water by using a plot of dissolved silica versus enthalpy: U.S. Geological Survey Journal of Research, v. 5, no. 1 , p. 49-52.

Geothermal, Geochemistry and geothermometry.

711. Truesde11, A. H., and Frye, G. A., 1977, Isotope geochemistry in geothermal reservoir studies: Dallas, Tex., Society of Petroleum Engineers SPE 6533, 8 p.

Geothermal, Geochemistry and geothermometry, Hydrology, Geophysics, Tabulated data.

712. Truesde11, A. H., and White, D. E., 1973, Production of superheated steam from vapor-dominated geothermal reservoirs: Geothermics, v. 2, no. 3-4, p. 154-173. Geology, Geothermal, Geophysics.

713. Turner, D. L., and Forbes, R. B., 1976, K-Ar studies in two deep basement holes - A new geologic estimate of argon blocking temperature for biotite [abs.]: American Geophysical Union Transactions, v. 57, no. 4, p. 353. Geology, Geothermal, Geochemistry and geothermometry, Geophysics. 
714. Union Geothermal Company of New Mexico, 1980, Index of exhibits: Union Geothermal Company of New Mexico, (Union $0 i l$ Company of California, Union Geothermal Division, Los Angeles, Calif.), 58 p.

Geology, Geothermal, Geochemistry and geothermometry, Hydrology, Geophysics, Collected technical articles, Tabulated data.

715 1981 , Computer modeling of potential impacts of 50 MWe commercial development of the Redondo Creek geothermal field, New Mexico, upon geothermal fluids discharge into the Jemez River: Union Geothermal Company of New Mexico (Union Oil Company of California, Union Geothermal Division, Los Angeles, Calif.), 42 p.

Geology, Geothermal, Geophysics, Modeling methods and background, Modeling applications, Modeling evaluation and documentation, Tabulated data.

716. Union 0il Company of California, 1975, Baca well number 11 - Scale evaluation: Los Angeles, Calif., Union 0il Company of California, Union Geothermal Division, 90 p. Geology, Geothermal, Geochemistry and geothermometry, Hydrology, Geophysics, Tabulated data.

717 . 1978 , Historical cost data, reconciliation of summary schedules: Los Angeles, Calif., Union 0il Company of California, Union Geothermal Division, 6 p. Geothermal, Tabulated data.

718 n.d., Electric logs for Baca wells number 10 to 14: Los Angeles, Calif., Union 0il Company of California, Union Geothermal Division, 8 logs.

Geology, Geothermal, Geochemistry and geothermometry, Geophysics, Tabulated data.

719. n.d., Lithology logs, Baca wells number 4 to 16 : Los Angeles, Calif., Union 0il Company of California, Union Geothermal Division, 8 logs. Geology, Geothermal, Tabulated data. 
720 . n.d., Summary sheets for Baca wells number 4 to 16: Los Angeles, Calif., Union Oil Company of California, Union Geothermal Division, $3 \mathrm{p}$.

Geology, Geothermal, Hydrology, Tabulated data.

721 . n.d., Temperature and pressure surveys, Baca wells number 4 to 8 and 10 to 16: Los Angeles, Calif., Union oil Company of California, Union Geothermal Division, $888 \mathrm{p}$.

Geothermal, Geochemistry and geothermometry, Hydrology, Geophysics, Tabulated data.

722 . n.d., Temperature gradient hole data 1970, 1972-1974 and location map: Los Angeles, Calif., Union 0il Company of California, Union Geothermal Division, 69 p. Geothermal, Geophysics, Tabulated data.

723 . n.d., Well summary reports and drilling histories, Baca Wells number 4 to 16: Los Angeles, Calif., Union Oil Company of California, Union Geothermal Division, 113 p Geology, Geotherma1, Hydrology, Tabulated data.

724. Union 0il Company of California, and Public Service Company of New Mexico, 1978 , Geothermal demonstration power plant - Project description: submitted to U.S. Department of Energy in response to Program Opportunity Notice $\mathrm{EG}-77-\mathrm{N}-03-1717,27 \mathrm{p}$. Geology, Geothermal, Hydrology, Geophysics.

725 . 1978, Geothermal demonstration power plant - Volume I, Project abstract: submitted to U.S. Department of Energy in response to Program Opportunity Notice $\mathrm{EG}-77-\mathrm{N}-03-1717,46 \mathrm{p}$. Geology, Geothermal, Tabulated data.

726 . 1978 , Geothermal demonstration power p1ant - Volume II, Technical and management proposal: submitted to U.S. Department of Energy in response to program opportunity Notice EG-77-N-03-1717, $152 \mathrm{p}$.

Geology, Geothermal, Geochemistry and geothermometry, Hydrology, Geophysics, Tabulated data. 
1978, Geothermal demonstration power plant - Volume III, Business proposal: submitted to U.S. Department of Energy in response to Program Opportunity Notice EG-77-N-03-1717, 41 p. Geothermal, Tabulated data.

728 1978, Geothermal demonstration power plant - Volume IV, Cost proposal: submitted to U.S. Department of Energy in response to Program Opportunity Notice $\mathrm{EG}-77-\mathrm{N}-03-1717,126 \mathrm{p}$. Geothermal, Tabulated data.

729. 1978 , Geothermal demonstration power plant - Volume V, Economics information: submitted to U.S. Department of Energy in response to Program Opportunity Notice EG-77-N-03-1717, $5 \mathrm{p}$. Geotherma1.

730. University of New Mexico, 1979, Station and well site archaeological analysis. An investigation into high altitude adaptations for the proposed Baca geothermal project: prepared by University of New Mexico, Albuquerque, New Mexico, Archaeology Department, for Union Oil Company of California, Union Geothermal Division, Los Angeles, California, and Public Service Company of New Mexico, Albuquerque, New Mexico, 168 p. Geology, Geothermal, Ecology, Tabulated data.

731. U.S. Bureau of Indian Affairs, 1980, Geothermal hydrology at Jemez Mountains, Ion balance and flow depletion: U.S. Bureau of Indian Affairs, 16 p. Geothermal, Geochemistry and geothermometry, Hydrology, Modeling applications, Correspondence, Tabulated data.

732. U.S. Bureau of Reclamation, 1969, Reconnaissance report on Jemez Project, New Mexico (with appended reports): Amarillo, Tex., U.S. Bureau of Reclamation, Region 5, 57 p. and appended reports and memoranda. Geology, Geothermal, Hydrology. 
733. U.S. Department of Agriculture and New Mexico State Engineer office, 1968 , Water and related land resources, Chama-0towi sub-basin, Upper Rio Grande Basin, New Mexico: U.S. Department of Agriculture and New Mexico State Engineer office preliminary report, 110 p. and 1 appendix.

Geochemistry and geothermometry, Hydrology, Ecology, Tabulated data.

734 . 1969, Water and related land resources, Chama-otowi sub-basin, Upper Rio Grande Basin, New Mexico, Appendix II, Supplement to Chama-0towi sub-basin preliminary report: U.S. Department of Agriculture and New Mexico State Engineer office preliminary report, 93 p. Geology, Hydrology, Tabulated data.

735 . 1974, Upper Rio Grande Basin, Water and related land resources: U.S. Department of Agriculture and New Mexico State Engineer office, 219 p. Geochemistry and geothermometry, Hydrology, Tabulated data.

736. U.S. Department of Energy, 1979, Draft environmental impact statement, Geothermal demonstration program, 50 MWe power plant, Baca Ranch, Sandoval and Rio Arriba Counties, New Mexico: U.S. Department of Energy DOE/EIS-0049-D, 305 p. Geology, Geothermal, Geochemistry and geothermometry, Hydrology, Ecology, Tabulated data.

737 . 1979 , Final environmental impact statement, Geothermal demonstration program, 50 MW power plant: U.S. Department of Energy DOE/EIS-0049-F, $762 \mathrm{p}$. Geology, Geothermal, Geochemistry and geothermometry, Hydrology, Ecology.

738 . 1979, Geothermal energy: U.S. Department of Energy DOE/OPA-0051, $15 \mathrm{p}$. Geothermal. 
739.

1980 , Geothermal demonstration program 50 MWe power plant, Baca Location No. 1, New Mexico Record of Decision: U.S. Department of Energy, 11 p., 1 attachment. Geothermal, Administrative papers.

740 1982 , Summaries of physical research in the geosciences - September 1982: U.S. Department of Energy DOE/ER-0145, $104 \mathrm{p}$. Geology, Geothermal, Geochemistry and geothermometry, Hydrology, Geophysics, Modeling methods and background, Modeling applications, Modeling evaluation and documentation, Review articles, Collected technical articles, Tabulated data.

741. U.S. Energy Research and Development Administration, 1975 , A bibliography, geothermal resources exploration and exploitation: Springfield, Va., U.S. Department of Commerce and U.S. Energy Research and Development Administration TID-3354, $383 \mathrm{p}$.

Geothermal, Bibliography.

742. U.S. Forest Service, 1977, Environmental statement geothermal - for Santa Fe National Forest: Albuquerque, N. Mex., U.S. Forest Service, S.W. Region, 165 p. Geology, Geotherma1, Geochemistry and geothermometry, Hydrology, Ecology.

743. U.S. Forest Service, and Earth Environmental Consultants, 1979 , Soils information for the proposed Baca geothermal project: prepared by U.S. Forest Service and Earth Environmental Consultants for Union 0il Company of California, Union Geothermal Division, Los Angeles, California, and Public Service Company of New Mexico, Albuquerque, New Mexico, $93 \mathrm{p}$.

Geology, Geothermal, Ecology, Tabulated data.

744. U.S. Geological Survey, 1965, Mineral and water resources of New Mexico: New Mexico Bureau of Mines and Mineral Resources Bulletin $87,437 \mathrm{p}$.

Geology, Hydrology. 
745 .

1978, Index to topographic maps of New Mexico: U.S.

Geological Survey, 1 sheet.

Geology, Bibliography.

746 .

1978 , List of Geological Survey geologic and water-supply reports and maps for New Mexico: U.S. Geological Survey, 39 p.

Geology, Geothermal, Geochemistry and geothermometry, Hydrology, Geophysics, Modeling methods and background, Modeling applications, Modeling evaluation and documentation, Bibliography.

747 .

1980 , Geothermal resources operational orders issued under the Geothermal Steam Act of 1970, (draft) GRo order 5. Plans of operation, permits, reports, records and forms: U.S. Geological Survey, 42 p. Geothermal.

748. Vetter, 0. J., and Campbe11, D. A., 1979, Scale inhibition in geothermal operations, Experiments with Dequest 2060 Phosphonate in Republic's East Mesa Field: Lawrence Berkeley Laboratory LBL-9089 GREMP-5, 56 p. Geothermal, Geochemistry and geothermometry, Tabulated data.

749. Ward, S. H., Ross, H. P., and Nielson, D. L., 1981 , Exploration strategy for high temperature hydrothermal systems in Basin and Range Province: American Association of Petroleum Geologists Bulletin, v. 65, no. 1, p. 86-122. Geotherma1.

750. Waring, G. A., 1965, Thermal springs of the United States and other countries of the world, A summary: U.S. Geological Survey Professional Paper 492, 383 p. Geotherma1, Tabulated data.

751. Water Resources Associates, Inc., 1977, Appendices II and III to hydrology of the region surrounding the valles Caldera: consultant report for Union oil Company of California, Union Geothermal Division, Los Angeles, California, 2 appendices.

Geotherma1, Hydrology, Tabulated data. 
752 .

1977, Hydrology, Jemez Mountains, New Mexico: consultant report for Union oil Company of California, Union Geothermal Division, Los Angeles, Calif., 24 p., 3 appendices.

Geothermal, Hydrology.

753.

1977, Model of streamflow depletion of the Jemez

River by geothermal development in the Valles Caldera, New Mexico (addendum to Water Resources Associates, Inc., 1977, Hydrology, Jemez Mountains, New Mexico): consultant report for Union 0il Company of California, Union Geothermal Division, Los Angeles, Calif., 12 p. Geothermal, Geophysics, Modeling evaluation and documentation.

754. Water Well Journal, 1973, Drilling for energy: Water Well Journal, July 1973 , p. 32-35.

Geology, Geothermal, Hydrology.

755. Weir, J.E., Jr., 1958, Geology and hydrology of the Valles Caldera, Sandoval County, New Mexico [abs.], in Guidebook of Black Mesa Basin (Northeastern Arizona): New Mexico Geological Society, 9 th Field Conference, p. 205. Geology, Hydrology.

756. Wells, S. G., Grambling, J. A., and Callender, J. F., eds., 1982 , Guidebook of Albuquerque Country II: New Mexico Geological Society, 33 rd Field Conference, 350 p. Geology, Geothermal, Geochemistry and geothermometry, Hydrology, Geophysics, Collected technical articles.

757. Wells, S. G., Lambert, P. W., and Callender, J. F., eds., 1981 , Environmental geology and hydrology in New Mexico: New Mexico Geological Society Special Publication 10 , $152 \mathrm{p}$. Geology, Geothermal, Hydrology, Collected technical articles, Tabulated data.

758. West, F. G., 1973, Geohydrology of the Jemez Plateau: Los Alamos Scientific Laboratory LA-UR-74-119, 7 p . Geology, Geothermal, Hydrology. 
759.

1973, Geohydrology of the Jemez P1ateau [abs.]:

American Geophysical Union Transactions, v. 54, no. 11, p. 1214-1215.

Geology, Geothermal, Hydrology.

760 .

1973, Regional geology and geophysics of the Jemez Mountains: Los Alamos Scientific Laboratory Informal Report LA-5362-MS, 7 p.

Geology, Geotherma1, Geophysics.

761 .

1974 , Dry hot rock project, in Guidebook of Ghost

Ranch: New Mexico Geological Society, 25 th Field

Conference, p. 355-358.

Geology, Geothermal, Geochemistry and geothermometry, Hydrology, Geophysics, Tabulated data.

762. West, F. G., and Purtymun, W. D., 1976, Geology of the LASL Fenton Hill Site [abs.]: American Geophysical Union

Transactions, v. 57 , no. 4, p. 349.

Geology, Geothermal, Geophysics.

763. West, F. G., Kintzinger, P. R., and Laughlin, A. W., 1975, Geophysical logging in Los Alamos Scientific Laboratory geothermal test hole no. 2: Los Alamos Scientific Laboratory Informal Report LA-6112-MS, 12 p.

Geology, Geothermal, Geophysics.

764. West, F. G., Kintzinger, P. R., and Purtymun, W. D., 1975, Hydrologic testing geothermal test hole no. 2: Los Alamos Scientific Laboratory Informal Report LA-6017-MS, 8 p. Geotherma1, Hydrology, Geophysics.

765. WESTEC Services, Inc., n.d., The Baca 50MW geotherma1 demonstration project: Public Service Company of New Mexico, Union Geothermal Company of New Mexico, and United States Department of Energy, 8 p.

Geology, Geothermal, Geochemistry and geothermometry, Hydrology, Geophysics. 
766. White, D. E., 1957, Magmatic, connate, and metamorphic waters: Geological Society of America Bulletin, v. 68 , no. 12 , part 1, p. 1659-1682.

Geothermal, Geochemistry and geothermometry, Geophysics, Tabulated data.

767 .

1957 , Thermal waters of volcanic origin: Geological Society of America Bulletin, v. 68, no. 12, part 1 , p. $1637-1658$. Geothermal, Geochemistry and geothermometry, Hydrology, Geophysics, Tabulated data.

768 . 1960 , Summary of chemical characteristics of some waters of deep origin, in Short papers in the geological sciences, Geological Survey research 1960: U.S. Geological Survey Professional Paper 400-B, p. B452-B454. Geochemistry and geothermometry, Tabulated data.

769. 1970, Geochemistry applied to the discovery, evaluation and exploitation of geothermal energy resources: Pre-publication proof, United Nations symposium on the development and utilization of geothermal resources, Pisa, Italy, $24 \mathrm{p}$.

Geothermal, Geochemistry and geothermometry, Tabulated data.

770. White, D. E., and Wil11ams, D. L., eds., 1975, Assessment of geothermal resources of the United States--1975: U.S. Geological Survey Circular 726, 155 p. Geothermal, Tabulated data.

771. White, D. E., Muffler, L. I. P., and Truesde11, A. H., 1971 , Vapor dominated hydrothermal systems compared with hot water systems: Economic Geology, v. 66, no. 1, p. 75-97. Geothermal, Geochemistry and geothermometry, Modeling applications, Tabulated data. 
772. Whitford Ecological Consultants, 1975, Report on reconnaissance of Redondo Creek, Redondo Border, Sulfur Canyon, Alamo Canyon and Valle Seco areas with proposal and budget estimates for biological baseline studies: consultant report for Union 0il Company of California, Union Geothermal Division, Los Angeles, California, 15 p. Geothermal, Ecology.

773 . 1975, Studies of rare and/or endangered species on the Union-Baca geothermal lease and surrounding area with discussion of other species: consultant report for Union $0 i 1$ Company of California, Union Geothermal Division, Los Angeles, California, 15 p.

Geothermal, Ecology.

774 . 1975, The biota of the Baca geothermal site: consultant report for Union 0il Company of California, Union Geothermal Division, Los Angeles, California, 123 p. Geothermal, Ecology.

775 . 1975, Winter activity and habitat use by elk in the Redondo Creek area with comments on activities and relative abundance of other species: consultant report for Union 0il Company of California, Union Geothermal Division, Los Angeles, California, 37 p.

Ecology.

776 . 1979, Stream ecology inventory. The biota of Redondo Creek, Sandoval County, New Mexico, for the proposed Baca geothermal project: consultant report for Union $0 i 1$ Company of California, Union Geothermal Division, Los Angeles, California, and Public Service Company of New Mexico, Albuquerque, New Mexico, 72 p. Hydrology, Ecology, Tabulated data.

777. Wigley, T. M. L., and Plummer, L. N., 1976, Mixing of carbonate waters: Geochimica et Cosmochimica Acta [Pergamon Press, Great Britain], v . 40, p. 989-995. Geology, Tabulated data. 
778. Willison, McNeil and Associates, 1979, A time domain survey of the Los Alamos region, New Mexico: Los Alamos

Scientific Laboratory Informal Report LA-7657-MS, 32 p. Geophysics, Tabulated data.

779. Wirth Associates, 1979, Land use inventory for the proposed Baca geothermal project: consultant report for Union 0il Company of California, Union Geothermal Division, Los Angeles, California, and Public Service Company of New Mexico, $42 \mathrm{p}$. Geology, Geothermal.

780. Witherspoon, P. A., Neumann, S. P., Sorey, M. L., and Lippmann, M. J., 1975, Modeling geothermal systems: Lawrence Berkeley Laboratory LBL-3263, 68 p. Geothermal, Modeling methods and background, Modeling applications, Modeling evaluation and documentation.

781. Wo1tz, David, 1972, The chemistry of ground waters in the Jemez area and a magnetic survey of a potential source of magmatic fluids: Albuquerque, N. Mex., University of New Mexico, unpublished M.S. thesis, 90 p. Geochemistry and geothermometry, Hydrology, Tabulated data.

782. Wood, G. H., and Northrop, S. A., 1946, Geology of the Nacimiento Mountains, San Pedro Mountain, and adjacent plateaus in parts of Sandoval and Rio Arriba Counties, New Mexico: U.S. Geological Survey $0 i 1$ and Gas Investigations Map 0M-57, scale 1:95,040, 1 sheet. Geology.

783. Wooding, R. A., 1957, Steady state free thermal convection of liquid in a saturated permeable medium: Journal of Fluid Mechanics, v. 2, p. 273-285.

Geothermal, Hydrology, Modeling methods and background.

784. Woodward, L. A., ed., 1970, Guidebook of Tyrone-Big Hatchet Mountains-Florida Mountains region: New Mexico Geological Society, $21 \mathrm{st}$ Field Conference, 176 p. Geology, Collected technical articles. 
785. Woodward, L. A., 1974, Tectonics of centra1-northern New Mexico, in Guidebook of Ghost Ranch: New Mexico

Geological Society, 25th Field Conference, p. 131-135.

Geology.

786 .

1977, Rate of crustal extension across the Rio

Grande Rift near Albuquerque, New Mexico: Geology, v. 5,

p. 269-272.

Geophysics.

787 .

1982, Tectonic framework of Albuquerque Country, in Guidebook to Albuquerque Country II: New Mexico

Geological Society, 33rd Field Conference, p. 141-145.

Geology.

788. Woodward, L. A., and Northrop, S. A., eds., 1976, Tectonics and mineral resources of Southwestern North America: New Mexico Geological Society Special Publication 6, 218 p.

Geology, Geothermal, Hydrology, Collected technical articles.

789. Woodward, L. A., Duchene, H. R., and Martinez, Ruben, 1977 , Geology of Gilman Quadrangle, New Mexico: New Mexico

Bureau of Mines and Mineral Resources Geologic Map 45, scale $1: 24,000$, I sheet.

Geology.

790. Woodward, L. A., Gibson, G. G., and Mclelland, Douglas, 1976, Geology of Gallina Quadrangle, Rio Arriba County, New Mexico: New Mexico Bureau of Mines and Mineral Resources Geologic Map 39, scale 1:24,000, 1 sheet. Geology.

791. Woodward, L. A., and others, 1974, Precambrian rocks of the southern Sierra Nacimiento, New Mexico, in Guidebook of Ghost Ranch: New Mexico Geological Society, 25 th Field Conference, p. 95-99.

Geology. 
792 . 1975, Tectonic map of the Rio Grande region from New Mexico-Colorado border to Presidio, Texas, in Guidebook of Las Cruces Country: New Mexico Geological Society, 26 th Field Conference, p. 239. Geology, Geophysics.

793. Wright, H. E., Jr., 1946, Tertiary and Quaternary geology of the lower Rio Puerco area, New Mexico: Geological Society of America Bulletin, v. 57, p. 383-456, plate 10 . Geology.

794. Wunder, Rainer, and Murphy, Hugh, 1978, Thermal drawdown and recovery of singly and multiply fractured hot dry rock reservoirs: Los Alamos Scientific Laboratory Informa1 Report LA-7219-MS, 15 p.

Geothermal, Modeling methods and background, Modeling applications, Modeling evaluation and documentation.

795. Zienkiewicz, 0. C., 1971, The finite element method in engineering science: London, McGraw-Hi11, 521 p. Modeling methods and background, Modeling applications, Modeling evaluation and documentation, Tabulated data. 
SUBJECT INDEX

Geology

$1,2,3,4,5,6,11,12,15,16,17,19,20,21,22,23,25,28$, $29,30,31,32,35,36,37,38,39,40,41,43,44,46,47,48$, $49,50,51,54,55,56,57,58,59,60,62,63,64,69,70,72$, $76,77,78,79,85,86,88,89,90,92,94,96,98,100,101,102$, $103,104,106,109,110,111,112,113,116,117,118,119,120$, $124,126,127,128,129,135,137,139,141,142,143,144,147$, $148,150,153,154,155,157,158,159,160,161,162,164,167$, $168,169,170,171,173,176,177,178,179,180,181,182,183$, $184,185,186,189,190,191,192,193,201,202,203,217,222$, $223,224,225,226,227,231,232,233,234,235,236,237,239$, $240,241,242,243,245,246,249,250,251,252,253,255,256$, $261,263,265,266,268,269,271,281,284,285,287,288,290$, $291,295,296,299,300,303,306,307,308,309,311,312,313$, $314,315,316,317,320,322,323,324,325,327,328,329,330$, $331,332,333,335,336,337,339,340,341,342,345,346,347$, $348,349,351,352,356,357,359,360,361,368,372,373,374$, $379,380,381,383,385,388,389,390,391,392,393,394,395$, $396,400,401,403,405,406,407,408,409,410,414,415,416$, $417,420,423,424,437,438,442,444,445,446,447,450,455$, $456,458,464,466,468,470,471,472,473,474,475,478,479$, $480,482,483,487,488,489,490,498,500,501,502,503,504$, $505,510,511,512,513,515,517,518,520,523,528,529,530$, $535,537,546,547,549,550,554,557,558,561,563,564,565$, $567,568,571,573,574,577,579,580,582,583,584,585,586$, $588,590,591,592,595,596,597,598,600,601,606,608,609$, $611,612,613,614,615,616,618,619,620,621,622,623,624$, $625,626,627,632,633,635,636,637,638,639,642,651,652$, $654,657,660,661,662,669,675,677,681,682,685,687,693$, $694,699,701,703,707,708,712,713,714,715,716,718,719$, $720,723,724,725,726,730,732,734,736,737,740,742,743$, $744,745,746,754,755,756,757,758,759,760,761,762,763$, $765,777,779,782,784,785,787,788,789,790,791,792,793$. 
Geothermal

$2,3,7,9,10,14,16,18,23,26,28,29,33,34,38,40,42$, $45,48,51,53,61,65,70,72,74,75,76,83,84,86,87,89$, $90,91,92,93,95,97,99,105,108,118,119,120,121,122$, $123,124,125,129,132,133,134,137,138,145,146,148,149$, $152,154,157,158,159,162,163,166,168,173,174,175,176$, $177,180,183,184,185,186,187,188,194,195,196,197,198$, $204,205,206,207,208,209,210,211,212,213,214,215,216$, $220,223,224,225,226,227,232,233,234,235,236,237,238$, $239,240,241,242,243,244,245,247,248,249,251,252,253$, $254,257,258,259,261,264,265,266,268,270,271,272,273$, $274,275,276,277,278,279,284,286,290,291,293,294,296$, $299,300,302,304,305,306,307,309,310,311,312,313,315$, $318,320,321,322,323,324,338,341,342,344,345,346,347$, $349,353,354,355,359,362,363,364,365,366,369,370,371$, $372,375,376,377,378,380,381,382,383,384,386,387,388$, $389,397,401,402,404,406,407,408,411,412,419,421,422$, $425,426,427,428,434,435,439,440,441,442,443,448,449$, $450,451,452,453,454,455,457,459,460,465,468,469,476$, $477,478,479,481,483,484,490,491,492,493,494,495,497$, $500,501,502,503,504,505,506,507,508,509,510,528,538$, $540,541,544,549,551,552,553,554,559,560,561,562,564$, $566,569,570,571,572,575,576,579,580,581,583,584,585$, $587,588,589,593,594,595,597,599,600,602,603,604,606$, $607,608,610,611,612,613,615,617,618,619,628,629,630$, $631,633,634,639,640,641,643,646,647,648,649,658,659$, $663,664,665,666,667,668,671,672,673,674,675,676,677$, $678,679,680,681,683,684,685,686,687,688,689,690,691$, $692,693,694,700,702,703,704,705,706,707,708,710,711$, $712,713,714,715,716,717,718,719,720,721,722,723,724$, $725,726,727,728,729,730,731,732,736,737,738,739,740$, $741,742,743,746,747,748,749,750,751,752,753,754,756$, $757,758,759,760,761,762,763,764,765,766,767,769,770$, $771,772,773,774,779,780,783,788,794$. 
Geochemistry and Geothermometry

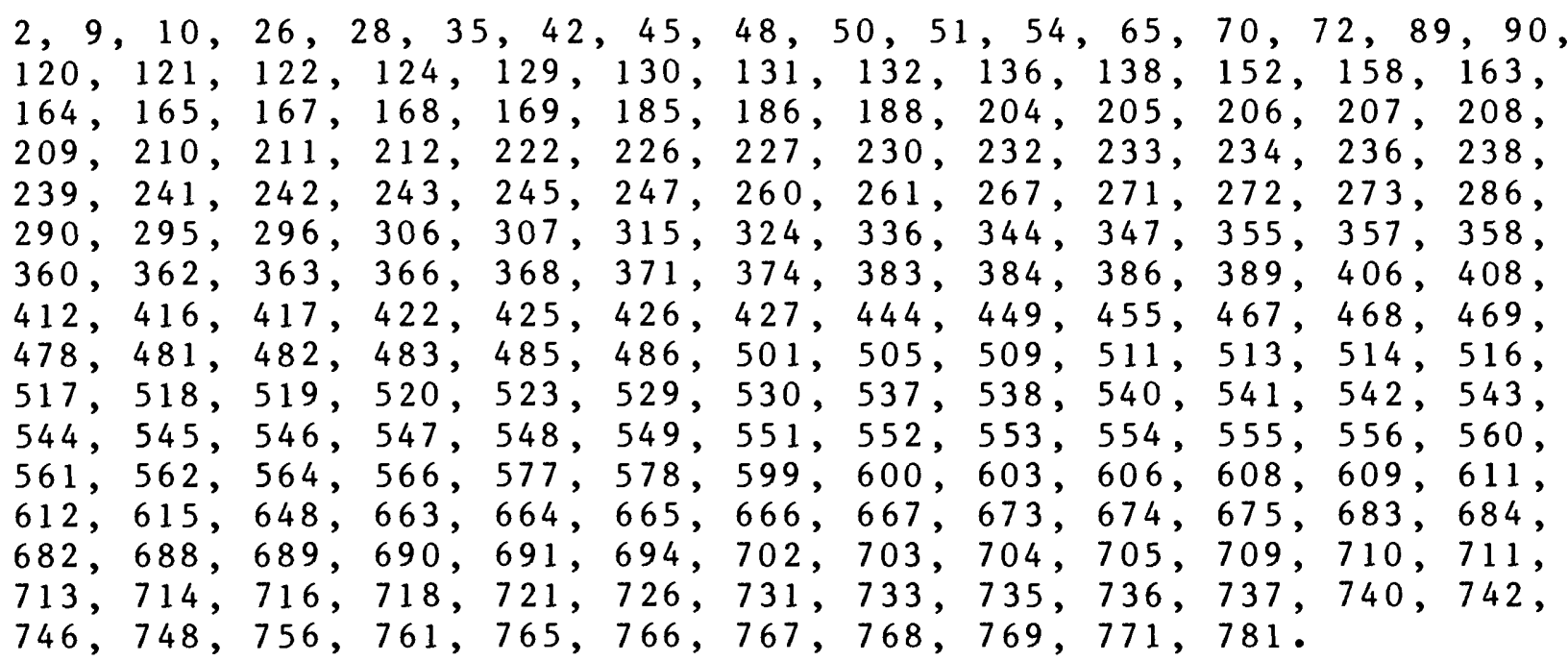

$1,2,3,5,6,13,22,24,26,27,28,29,33,38,42,45,47,48$, $50,51,52,66,67,68,70,71,72,73,77,78,79,80,81,82$, $83,84,92,100,102,106,114,119,121,122,123,124,130$, $131,132,134,135,148,150,151,154,156,158,164,165,176$, $180,185,186,188,194,198,199,203,224,225,230,232,233$, $234,236,237,238,239,240,241,242,243,245,247,249,251$, $252,254,256,257,258,259,262,265,267,268,270,271,272$, $273,274,281,282,283,286,289,290,292,295,299,306,314$, $315,316,319,320,324,334,336,337,340,341,343,347,348$, $350,359,366,367,375,395,396,399,400,403,405,406,411$, $412,413,418,420,426,427,429,436,437,438,439,444,449$, $455,457,461,462,463,464,465,467,470,478,483,485,486$, $488,490,498,499,500,501,503,505,506,510,511,513,514$, $516,517,518,519,520,521,522,523,524,525,526,527,528$, $529,530,531,532,533,534,535,537,538,539,540,541,542$, $543,544,545,546,547,548,549,550,551,552,553,554,555$, $556,561,564,566,573,574,575,578,587,588,598,600,605$, $606,607,611,612,613,619,631,632,633,643,644,645,646$, $648,650,653,655,656,657,658,659,661,668,673,677,680$, $681,684,685,686,689,693,694,695,696,697,698,699,702$, $703,704,705,706,711,714,716,720,721,723,724,726,731$, $732,733,734,735,736,737,740,742,744,746,751,752,754$, $755,756,757,758,759,761,764,765,767,776,781,783,788$. 
$13,22,24,27,47,70,112,114,136,200,214,224,225,226$, $230,260,289,290,298,323,335,343,350,366,395,396,398$, $399,400,403,405,407,443,491,496,561,567,582,598,610$, $650,730,733,736,737,742,743,772,773,774,775,776$.

\section{Geophysics}

$1,2,3,4,7,8,9,11,12,14,15,16,17,18,19,23,39,40$, $43,48,51,54,62,63,64,65,66,67,70,76,78,86,87,88$, $89,90,93,94,95,96,97,102,104,107,109,115,120,121$, $124,127,139,140,141,143,144,145,157,173,182,183,184$, $185,186,188,190,191,203,213,214,218,219,221,222,223$, $224,226,232,234,239,245,247,251,252,253,254,257,258$, $259,263,268,272,280,281,291,305,308,309,310,311,312$, $313,316,320,323,324,325,326,328,339,340,342,346,353$, $357,358,360,365,370,371,384,386,387,391,401,402,406$, $407,418,423,424,426,427,450,451,452,455,466,468,470$, $479,482,483,484,489,490,495,500,501,502,504,505,512$, $536,549,550,558,562,568,569,572,575,576,577,579,581$, $587,588,589,590,591,592,593,594,595,597,599,600,602$, $604,606,607,615,616,617,626,631,637,638,641,643,651$, $652,662,670,679,701,703,705,708,711,712,713,714,715$, $716,718,721,722,724,726,740,746,753,756,760,761,762$, $763,764,765,766,767,778,786,792$.

\section{Modeling Methods and Background}

$24,71,74,75,83,84,125,172,174,175,186,194,195,196$, $283,301,319,354,369,382,384,387,419,428,431,432,433$, $434,441,477,497,498,499,507,510,559,647,648,649,700$, $709,715,740,746,780,783,794,795$.

\section{Modeling Applications}

$24,71,75,83,86,99,108,120,174,175,186,187,194,229$, $244,282,283,321,341,345,346,369,384,428,430,431,432$, $433,435,452,498,499,510,559,560,715,731,740,746,771$, $780,794,795$. 
Modeling Evaluation and Documentation

$71,74,186,197,228,229,283,297,429,431,432,433,498$, $499,508,560,715,740,746,753,780,794,795$.

Bibliography

$29,80,81,82,227,286,302,354,383,505,672,678,741,745$, 746 .

Review Articles

$175,187,280,286,304,372,397,413,440,448,606,671,740$.

\section{Textbook}

$29,186,319,354,471,648$

\section{Collected Technical Articles}

$29,40,49,111,175,188,226,227,239,245,280,303,317$, $319,354,383,384,397,404,406,473,474,559,606,611,613$, $640,714,740,756,757,784,788$.

\section{Administrative Papers}

739.

Correspondence

671,731 
Tabulated Data

$5,15,16,18,19,27,28,29,35,47,50,52,53,60,62,63$, $64,65,66,67,70,71,72,76,78,79,87,88,101,102,106$, $108,112,115,121,124,129,130,131,135,136,144,146,148$, $149,150,151,152,154,155,156,162,164,165,171,176,180$, $186,194,198,199,205,206,207,208,210,212,213,214,220$, $223,224,225,227,230,236,238,239,242,243,245,254,256$, $257,258,259,262,267,268,271,272,273,274,275,278,279$, $282,283,289,290,295,296,302,305,307,309,310,312,314$, $315,320,321,322,323,325,332,334,337,344,345,348,354$, $358,361,362,363,366,368,383,386,389,391,392,395,396$, $397,399,400,401,403,405,406,408,420,422,425,426,436$, $437,443,444,449,461,462,464,465,467,469,476,477,478$, $482,483,485,487,488,490,496,498,499,509,510,511,513$, $514,515,516,517,518,519,520,521,522,523,524,525,526$, $527,528,529,530,531,532,533,534,537,538,539,540,541$, $542,543,544,545,546,547,548,549,550,551,552,553,554$, $555,558,560,561,564,569,572,574,575,577,578,581,590$, $594,595,598,599,600,603,605,606,608,609,611,612,613$, $619,643,644,645,650,659,663,664,665,666,667,668,673$, $694,679,680,681,683,685,686,688,694,696,698,703,704$, $705,706,709,711,714,715,716,717,718,719,720,721,722$, $723,725,726,727,728,730,731,733,734,735,736,740,743$, $748,750,751,757,761,766,767,768,769,770,771,776,777$, $778,781,795$. 
Aamodt, R. L.: 2, 3, 4 .

Abrahams, J. H., Jr.: 5, 6, 47 .

Adams, W. H.: $529,540,541,544,548$.

Ahearne, John: 7 .

Aiken, C. L. V.: 8 .

Albright, J . N . : 9, 10, 11, 12, 13, 346, 694 .

Albuquerque Journal: 14 .

Aldrich, M. J., Jr.: 15 .

Alexander, E. C., Jr.: 468 .

Alexander, Shari: 688,689 .

Alplekin, Omer: 590 .

Ander, M. E.: $16,17,18,19$.

Anderson, J . B . : 20, 21 .

Anderson, R. Y.: 22 .

Andrews, Bob: 23 .

Andrews, Charles: 24 .

Anonymous : 25 .

Anspach, E. V.: 334 .

Apley, W. J.: 132 .

Applied Geophysics, Inc.: 26 .

Apt, K. E.: 27,598 .

Armenta, Eddie: 28 . 
Armstead, H. C. H.: 29 .

Armstrong, A. K.: 30,31 .

Armstrong, R. L.: 32 .

Arnston, R. H.: 163 .

Atkinson, P. G.: 33,34 .

Bachman, G. $0 .: 35$.

Bailey, R. A.: $36,37,38,39,40,41,333,586,636,637$, $638,641,642$.

Balagna, J. C. R.: 42 .

Balagna, J . P .: 501 .

Baldridge, W. S.: 43,44 .

Ba1dwin, Brewster: 682 .

Ba11, J. W.: 45 .

Ballance, W. C.: $50,348,349$.

Ba1tz, E. H.: $6,46,47$.

Ba1tz, E. H., Jr.: 333 .

Barker, Colin: 48 .

Bas1er, J.A.: 165 .

Beaumont, E. C.: 49 .

Beck, A. E.: 387 .

Becker, N. M.: 50, 542, 543 .

Be11, E. J . : 708 .

Beltrame, R. J.: 51 .

Berger, L. R.: 52 .

Bernhardt, C. A.: 469 . 
Berry, G. W.: 53 .

Best, M. G.: 54 .

Beverage, J. P.: 262 .

Bickford, M. E.: 55 .

Bickham, R. E.: 593 .

Bingler, E. C.: $56,57,58,59,60$.

Birdseye, H. S.: 61 .

Birdwe 11 Division: $62,63,64,65,66,67$.

Black and Veatch Consulting Engineers: 68 .

Black, B. A.: $69,295$.

Blair, A. G.: 70 .

Blair, P. M.: 71 .

B1air, S. C.: 203 .

B 1ick, J. C.: 217 .

B1iss, J. D.: 72 .

Bloodgood, D. W.: 73 .

Bodvarsson, G. S.: $74,75,76$.

Bolivar, S. L.: 232,233 .

Borland, J. P.: 199 .

Borton, R. L.: $77,78,79,80,81,82$.

Bоуle, J. M.: 83 .

Bradford, E.: 649 .

Bredehoeft, J. D.: 84,498 .

Bridwe11, R. J .: 85,86 . 


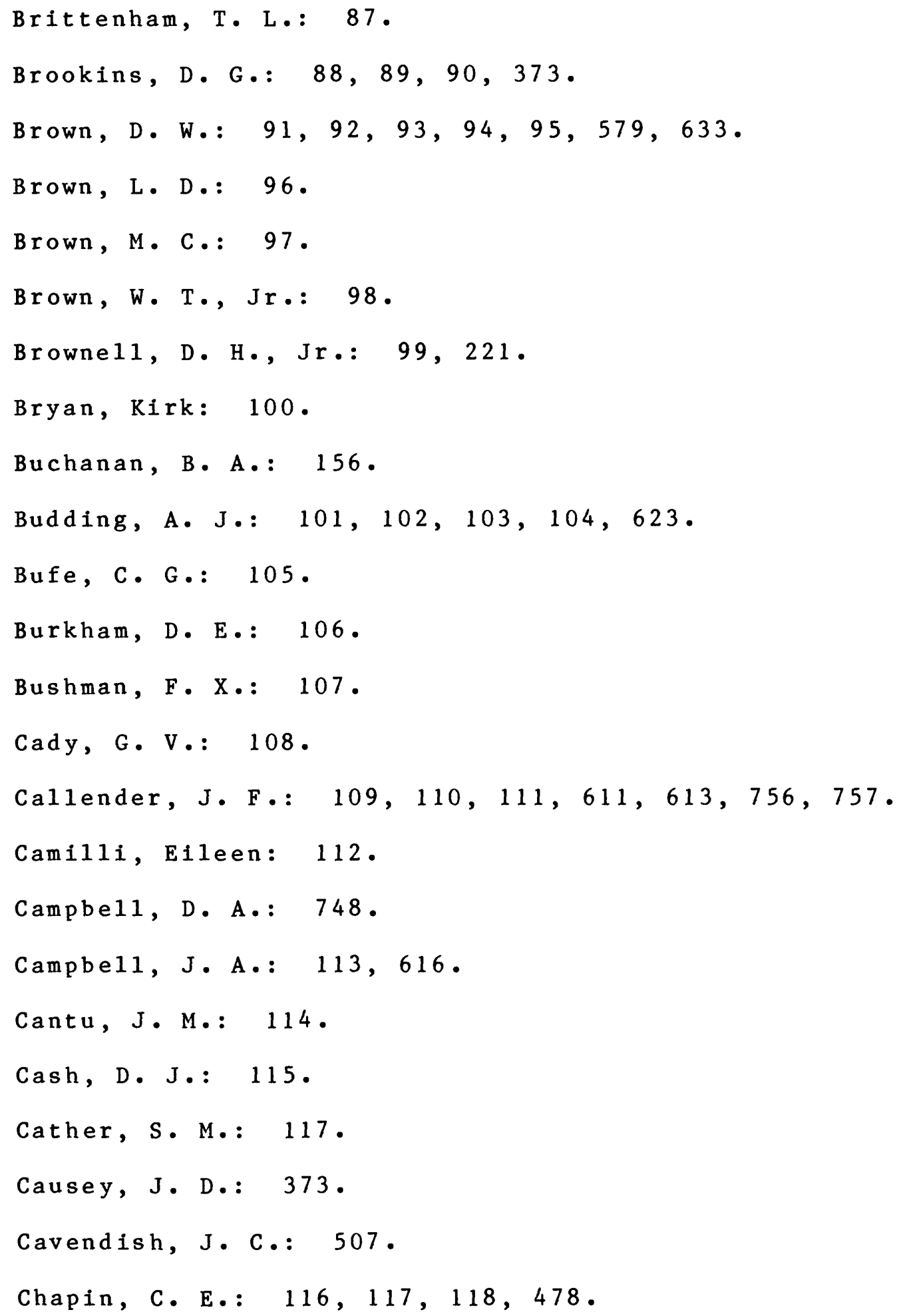


Charles, R. W.: 119, 120, 501 .

Chasteen, A. J.: 121 .

Chaturvedi, Lokesh: $122,123,124$.

Chau, W. C.: 125 .

Cheng, Ping: 125 .

Chenoweth, W. L.: 126 .

Christiansen, R. L.: 127,391 .

Church, F. S.: 128 .

C1ark, J. D.: 129, 130, 131 .

C1arke, J.: 218,219 .

C1iff, W. C.: 132 .

C1inton, N. J.: 331 .

Co11ie, M. J.: 133 .

Combs, Jim: 134 .

Conover, C. S.: 135,697 .

Controls for Environmental Pollution, Inc.: 136 .

Cook, F. A.: 137,558 .

Cooper, J. B.: 530 .

Coplen, T. B.: 138,449 .

Corde11, Lindrith: 139, 140, 141, 142, 143 .

Core Laboratory, Inc.: 144 .

Corwin, R. F.: 145 .

Costain, J. K.: 146 .

Cowan, M. J.: 147 . 
Creer, J.M.: 132 .

Crow, B. M.: 148 .

Cummings, R. G.: 149 .

Cushman, R. L.: 150,151 .

D'Amore, Franco: 152 .

Darton, N. H.: $153,154,155$.

Daugherty, L. A.: 156 .

Davis, A. H.: 324 .

Decker, E. R.: 157 .

Dellechaie, F. A.: 158 .

Dennis, B. R.: 159 .

Denny, C. S.: 160,161 .

Denton, R.: 162 .

Dickson, F. W.: 163 .

Dinwiddie, G. A.: 164,165 .

Dipippo, R.: 166 .

Dodson, J. G.: 609 .

Doe, B. R.: $167,168,169,170$.

Doe11, R. R.: 171 .

Domenico, P. A.: 172 .

Dona1dson, I. G.: 173, 174, 175, 435 .

Dondanville, R. F . : 176,177 .

Donne11y, J. M.: 234 .

Dorn, G. A.: 311 . 
Duchene, H. R.: $178,179,789$.

Dunigan Enterprises, Inc.: 180 .

Duschatko, R. W.: 181 .

Earth Environmental Consultants: 743 .

Eaton, G. P.: 182 .

Eddy, Andrea: $183,374,615$.

Edwards, C. L.: 184,570 .

Eichelberger, J. C.: 185 .

Elder, J. W.: 186 .

E11is, A. J.: 187 .

Elsner, D. B.: 188 .

Elston, W. E.: $189,190,191,192,627$.

Ely, R. W.: 597 .

Enyart, Eugene: 315.

Epis, R. D.: 669 .

Epstein, Samue1: 362,363 .

Fagadau, S. P.: 193 .

Faust, C. R.: 194, 195, 196, 197, 198,429,430,431,432,433, 434 .

Ferenbaugh, R. W.: 544 .

Fischer, E. E.: 199.

Fisher, D. W.: 485 .

Flavil, P.: 200 .

Flesch, G. A.: 201, 202 .

Fontes, J. C.: 214 . 
Foote, H. P.: 203 .

Forbes, R. B.: 455,713 .

Foster, F. W.: 107 .

Fournier, R. 0.: 204, 205, 206, 207, 208,209,210,211,212, 710 .

Friedman, Irving: 476 .

Friewa1d, D. A.: 213 .

Frind, E. $0 .: 499$.

Fritz, Peter: 214 .

Frye, G. A.: 711 .

Fuchs, R. L.: 215,216 .

Galati, M. S.: 34 .

Galusha, Ted: 217 .

Gambil1, D. T.: 386 .

Gamble, T. D.: 218,219 .

Gardner, J. N.: 235 .

Garg, S. K.: 99, 220, 221, 253, 576 .

Gelhar, L. W.: 301 .

Gentry, R. V.: 222 .

Geonomics Inc.: $223,224,225$.

Geothermal Resources Council: 226 .

Geothermics: 227 .

Geotrans, Inc.: 228, 229 .

Gibson, G. G.: 790 .

Gladney, E. S.: 44, 230 . 
Glover, Lynn, III: 146 .

Goff, F. E .: 231, 232, 233, 234, 235,236,237,238,239,240, $241,242,243,284,483$.

Golabi, Kamal: 244 .

Goldstein, N. E.: 245 .

Gottfried, David: 246 .

Goubeau, W. M.: 218,219 .

Gould, T. L.: 247 .

Goya 1, K. P . : 248,321 .

Grambling, J.A.: 756 .

Granger, H. C.: 249 .

Grant, Keith: 250 .

Grant, M. A.: 251, 252, 253, 254, 649.

Griggs, R. L •: $135,255,256$.

Grigsby, D. $0 .: 236$.

Grim, P. J.: 53 .

Gross, R. S.: 651 .

Group Seven, Inc.: 257,258 .

Gulati, M. R.: 259 .

Gustafson, E. P.: 312 .

Gutschick, Vincent: 260,562 .

Haas, J. L., Jr.: 261, 505 .

Hack, J. T.: 128 .

Haenel, R.: 20 .

Hale, W. E.: 262 . 
Hamilton, Warren: 263 .

Hammond, A: 264 .

Hano1d, R. J.: 12 .

Hansen, W. R.: 545 .

Hardee, H. C.: 265 .

Harder, Vicki: 266 .

Hare, R. F.: 267 .

Harlow, F. H.: 268 .

Harrington, E. R .: 269, 270 .

Harris, R. F.: 672 .

Hartman, Haro1d: 569.

Hartz, J. D.: $271,272,273,274$.

Harvey, D. J.: 275 .

Hatton, K. S.: $276,277,278,279$.

Hawley, J. W.: 280 .

Hea1y, F. G.: 281 .

Hearne, G. A.: 282,283 .

Heiken, Grant: $284,353$.

Helmick, Catherine: 285 .

Hemley, J. J.: 286 .

Henbest, L. G.: 287 .

Henderson, Janius: 288 .

Herceg, J. E.: $289,290,531,532,533,534$.

Hermance, J. F.: 291 . 
Herrick, C. C.: 120 .

Hershman, A.: 183 .

Hicks, J. D.: 292 .

Hightower, M. M.: 293 .

Hildenbrand, T. G.: 143 .

Hill, J. H.: 294 .

Hiss, W. L.: 295.

Holland, H. D.: 296.

Holman, W. R.: 245.

Hoover, D. B.: 145 .

Horne, R. N.: 297 .

Howard W. Henry and Company: 298, 299.

Huestis, S . P . 17 .

Hulen, J. B.: 300 .

Huttrer, G. W.: 215, 216 .

Huyakorn, P. S.: 301 .

Icerman, Larry: 28, 302 .

Ike $1 \mathrm{man}, \mathrm{J} . \mathrm{A} .: 53$.

Ingersol1, R. V.: 303 .

Isselhordt, C. F.: 628 .

Jackson, D.: 481 .

Jaffe, F. C.: 304 .

Jaksha, L. H.: 591, 651 .

James, Russe11: 305 . 
Jensen, M. L.: 306,307 .

Jiracek, G. R.: $308,309,310,311,312,313$.

Jobin, D. A.: 314 .

Johansen, Steven: 535 .

John, E. C.: 315 .

Johnson, A. I.: 316 .

Johnson, R. B . : 317 .

Johnson, Tom: 318 .

Jordon, H. S.: 536 .

Kaczmarek, Zdzislaw: 319 .

Kappelmeyer, $0 .: \quad 320$.

Kassoy, D. R.: 321 .

Kaufman, Alvin: 322 .

Kaufman, E. L.: 323,610 .

Ke11er, C. E.: 324 .

Keller, G. R.: 143 .

Keller, M. D.: 325,326 .

Kelley, V. C.: $327,328,329,330,331,332,333$.

Ke11y, C1yde: 334 .

Ke11y, P. P.: 335 .

Ke11y, T. E.: 336 .

Kennedy, W. R.: 537,538 .

Kennon, F. W.: 337 .

Kerr, R. A •: 338 . 
Keys, W. S . : 339 .

King, N. R.: 612 .

Kintzinger, P. R : $340,341,342,763,764$.

Kirkpatrick, T. $0 .: 343$.

Koenig, J. B.: 344 .

Kolstad, C. D.: $345,346,347$.

Koopman, F. C.: 348,349 .

Koster, W. J.: 350 .

Kottlowski, F. E.: 142, 351, 352 .

Kron, Andrea: 237,353 .

Kruger, Paul: $354,355,559,603$.

Kudo, A. M.: $98,332,356$.

Kunkler, J. L.: 357,358 .

Kutina, Jan: 359 .

Lachenbruch, A. H.: 594 .

Lakatos, Stephen: 360 .

Lambert, P. W.: 361,757 .

Lambert, S. J.: 362,363 .

Lamers, M. D.: 364 .

Lane, M. E.: 415 .

Laney, Randy: 365 .

Langhorst, G. J.: 366 .

Lanphere Reporting Service: 367 .

Larsen, E. S., III: 368 . 
Larson, D. W.: 265 .

Lasseter, T. J .: 369 .

Lattanner, A. V.: 370 .

Laughlin, A. W.: $8,89,90,183,347,365,371,372,373,374$, $375,376,377,378,379,380,381,763$.

Laumbach, D. D.: 382 .

Lawrence Berkeley Laboratory: 383,384 .

Lee, V. J : : 27 .

Lee, W. T.: 385 .

Levitte, D.: 386 .

Lewis, T. J.: 387 .

Lindgren, Waldemar: 388,389 .

Linville, B.: 12 .

Lipman, P. W.: $127,390,391$.

Lippmann, M. J : $\quad 369,780$.

Long, P. E.: 392 .

Lookingbi11, J. L . : 393,394 .

Los Alamos National Laboratory: $395,396,397$.

Los Alamos Scientific Laboratory: $398,399,400,401,402,403$, $404,405,406,407$.

Lovering, T. G.: 408 .

Luedke, R. G.: 409 .

Lyford, F. P.: 706 .

Machette, M. N.: 410 .

Maddox, J. D.: 411 . 
Maes, Max: 539, 542, 543 .

Mahon, W. A. J.: 412 .

Mamet, B. L.: 31 .

Mangold, D. C.: 413 .

Manley, Kim: 414,415 .

Mannhard, G. W.: 612 .

Mansfield, G. R.: 416,417 .

Mansure, A. J .: 418 .

Marron, J. K.: 605 .

Martin, J. C.: 419 .

Martinez, Ruben: 789 .

Matlick, J. S.: 628 .

Mauger, Harry: 130 .

Maxwe11, B. W.: 420 .

Maxwe11, J. C.: $240,421$.

Mazor, E.: 422 .

McGetchin, T. R.: $345,346,347,423,424$.

McKenzie, W. F.: 425 .

McLe1land, Douglas: 790 .

McPhar Geophysics: 426,427 .

Mehnert, H. H.: 35 .

Mercer, James W.: 194, 195, 196, 197, 198,428,429,430,431, $432,433,434,435$.

Mercer, Jerry W.: $436,437,438$.

Miller, D. W.: 248 . 


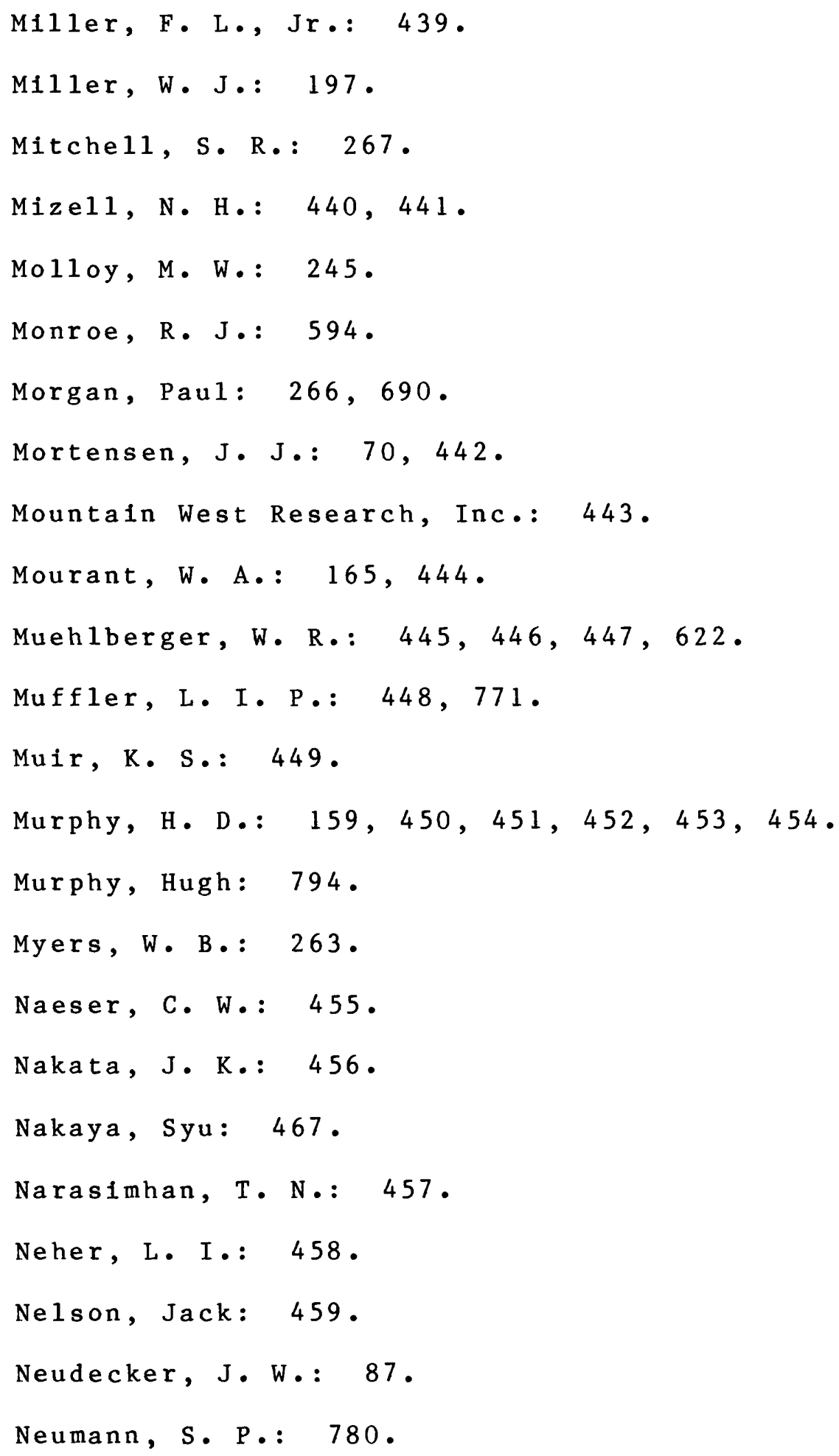


New Mexico Energy Institute: 460 .

New Mexico Interstate Stream Commission: 461, 462 .

New Mexico State Engineer Office: 461, 462, 463, 464, 465, 733, 734,735 .

Newton, C. A.: 466 .

Nielson, D. L.: 300,749 .

Nishimura, Masakichi: 467 .

Norman, D. I.: 468,469 .

North American Rockwell Corporation: 470 .

Northrop, S. A.: $471,472,473,474,475,782,788$.

Norton, D. R.: 476 .

O'Sullivan, M. J.: 74,477 .

$01 \mathrm{mstead}$, F. H.: 476 .

01sen, K. H.: 478, 479, 591 .

Otte, Care1: 354 .

Owen, D. E.: 250,480 .

Owen, L. B.: 481 .

Owens, J.W.: 540,546 .

Ozima, M.: 482 .

Palciauskas, V. V.: 172 .

Pallister, J. S.: 390 .

Papadopulos, I. S.: 84 .

Papadopulos, S. S.: 499 .

Parker, M. D.: 312 .

Pearson, Chris: 483,484 . 
Pearson, F. J., Jr.: 485,486 .

Perkins, P. C.: 487 .

Perry, F. V.: 44 .

Peters, R. J.: $545,546,547$.

Peterson, H. V.: 488 .

Pettitt, R. A.: $376,377,489,490,491,492,493,494,495$, 549,633 .

Pilz, W. R.: 496 .

Pinder, G. F.: 434, 435, 497, 498, 499 .

Pitrat, C. W.: 623 .

Plummer, L. N.: 485,777 .

Posson, D. R.: 295 .

Potter, J. M.: 500, 501 .

Potter, R. M.: 4, 93, 94, 95, 453, 502, 503, 504.

Potter, R. W., II: 206, 505 .

Pracht, W. E.: 268 .

Prats, M.: 506 .

Price, H. S.: 507 .

Priest, K. F.: 131 .

Pritchett, J.W.: 99, 220, 221, 508, 509.

Prostka, H. J.: 391 .

Pruess, Karsten: 510 .

Public Service Company of New Mexico: 724, 725, 726, 727, 728, 729 . 
Purtymun, W. D.: 5, 6, 47, 50, 151, 315, 511,512,513, 514, $515,516,517,518,519,520,521,522,523,524,525,526,527$, $528,529,530,531,532,533,534,535,536,537,538,539,540$, $541,542,543,544,545,546,547,548,549,550,551,552,553$, $554,555,762,764$.

Rainwater, F. H.: 556 .

Ramberg, I. B . : 557,558 .

Ramey, H. J •, Jr .: 559, 672 .

Rapport, Amy: 560 .

Rea, K. H.: 260,561, 562.

Read, C. B.: $49,287,317,474$.

Reagan, A. B.: 563,564, 565 .

Reed, M. J.: 566 .

Reeves, H. V., Jr.: 567 .

Reiland, L. J.: 262 .

Reilinger, R. E.: 568 .

Reiter, Marsha11: 418,569,570,571, 572 .

Renick, B. C.: 573,574 .

Republic Geothermal, Inc.: 575 .

Rice, L. F.: 576 .

Rice, M. H.: 509 .

Riecker, R. E.: 577 .

Rightmire, C. T.: 486 .

Riney, T. D.: 509 .

Rocky Mountain Geochemical Corporation: 578 .

Roegiers, J.C.: 579,580 . 
Rogers Engineering Company, Inc.: 581 .

Romer, A. S.: 582 .

Roquemore, G. R.: 708 .

Ross, C. S.: 41, 583, 584, 585, 586,641,642.

Ross, H. P.: 749 .

Rowe, J . J.: 207 .

Rowley, J. C.: 87 .

Rubin, Hille1: 587,588 .

Sabo, D. G.: 496 .

Sageev, A.: 589 .

Saleem, B. A.: 83 .

Sanford, A. R.: 590, 591, 592 .

Sanyal, S. K.: 593 .

Sargent, K. A.: 390 .

Sass, J. H.: 594, 595 .

Saucier, A. E.: 596 .

Savage, W. U.: 597 .

Sawkins, F. J.: 468 .

Sayer, Suzanne: 238 .

Schiager, K. J.: 598 .

Schubert, Gerald: 599 .

Schwartz, G. M.: 600 .

Sears, R. S.: 601 .

Segar, R. L.: 602 . 
Semprini, Lewis : 603 .

Sestini, G.: 604 .

Shaerer, C.: 570 .

Shafer, B. A.: 605 .

Shaw, D. R.: 505 .

Shaw, H. R.: 639,640 .

Sherwood, P. B.: 606 .

Sheu, J. P.: 607 .

Sibbitt, W. L.: 608,609 .

Siciliano, C. L. B.: 323,610 .

Siemers, C. T.: 611, 612, 613 .

Siems, P. L.: 614 .

Simmons, Gene: 615 .

Sinha, A. K.: 146 .

S1ack, P. B.: 616 .

Slemmons, D. B.: 617 .

Slodowski, T. R.: 618,619 .

Smith, C. T.: $620,621,622,623,624,625$.

Smith, Christian: 310,311 .

Smith, E. I.: 626,627 .

Smith, J. L.: 628 .

Smith, M. C.: 95, 629, 630,631,632,633,634.

Smith, R. L.: $40,41,409,586,635,636,637,638,639,640$, 641,642 .

Smithson, S. B.: 557,558 . 
Somerton, W. H.: 643 .

Sorensen, E. F.: 644,645 .

Sorey, M. L.: $254,646,647,648,649,780$.

Southwegt Environmental Research and Development Corporation: 650 .

Spence, William: 651,652 .

Spiege1, Z.E.: $653,654,655,656,657$.

Stallman, R. W.: 658 .

Starkey, Arlene: 28 .

State of New Mexico District Court: 659.

Stearns, C. E.: 660 .

Stearns, H. T.: $661,662,663$.

Stearns, N. D.: 663 .

Stearns-Roger, Inc.: $664,665,666,667,668$.

Steven, T. A.: 669 .

Stewart, B. S.: 240 .

Stoker, A. K.: $355,541,547$.

Stormer, C. J., Jr.: 670 .

Stoy, Michae1: 671 .

Stoyer, C. H.: 691 .

Straus, J. M.: 599 .

Sudo1, G. A.: 672 .

Summers, W. K.: 673, 674, 675,676,677,678,679,680,681 .

Sun, Ming-Shan: 682 . 
Swanberg, C. A.: $266,683,684,685,686,687,688,689,690$, 691,692 .

Tanaka, Kazuhiko: 467 .

Taylor, G. C., Jr.: 698 .

Teilborg, J.R.: 605 .

Terra Tek, Inc.: 693 .

Tester, J. W.: $70,452,453,609,694$.

Thatcher, L. L.: 556 .

Theis, C. V.: $135,695,696,697,698$.

Thil1, R. E.: 580 .

Thomas, S. D.: 198 .

Titus, F. B., Jr.: 699 .

Tocher, D.: 597 .

Toppozada, T. R.: 590 .

Toronyi, R. M.: 700 .

Torrence, K. E.: 607 .

Towle, J.E.: 701 .

Trainer, F. W.: 295, 702, 703, 704, 705, 706, 707 .

Trexler, D. T.: 708 .

Truesde11, A. H.: 152, 208, 209, 210, 211, 425, 510,709,710, $711,712,771$.

Ts ang, C. F.: 74 .

Turcotte, D. L.: 607 .

Turner, D. L.: 713 .

Umana, A.: 355 .

Union Geothermal Company of New Mexico: 714, 715 . 
Union 0il Company of California: $716,717,718,719,720,721$, $722,723,724,725,726,727,728,729$.

University of New Mexico: 730 .

U.S. Bureau of Indian Affairs: 731 .

U.S. Bureau of Reclamation: 732 .

U.S. Department of Agriculture: $733,734,735$.

U.S. Department of Energy: $736,737,738,739,740$.

U.S • Energy Research and Development Administration: 741 .

U.S. Forest Service: 742,743 .

U.S. Geologica1 Survey: $744,745,746,747$.

Varga, R. S.: 507 .

Vetter, 0. J.: 748 .

Vidale, Rosemary: 42 .

Wagner, W. L.: 496 .

Ward, S. H.: 749 .

Waring, G. A.: 663,750 .

Water Resources Associates, Inc.: 751, 752, 753 .

Water We11 Journa1: 754 .

Waters, A. C.: 239 .

Weinaug, C. F.: 71 .

Weir, J. E., Jr.: 5, 755 .

We11s, L. E.: 593 .

We11s, S. G.: 756,757 .

West, F. G.: $8,375,376,377,548,549,758,759,760,761$, $762,763,764$.

WESTEC Services, Inc.: 765 . 
Westrich, H. R.: 185 .

Wetheril1, G. W.: 55 .

White, D. E.: 211, 448,712,766,767,768,769,770,771.

Whitford Ecological Consultants: $772,773,774,775,776$.

Whitford, W. G.: 200 .

Wigley, T. M. L.: 777 .

Wilbur, A. C.: 411 .

Wi11iams, D. L.: 770 .

Williams, R. E.: 87 .

Willison, McNeil and Associates: 778 .

Wilson, M. D.: 202 .

Wirth Associates: 779 .

Witherspoon, P. A.: $369,457,780$.

Wo1tz, David: 781 .

Wood, G. H.: 475,782 .

Wooding, R. A.: 783 .

Woodward, L. A.: $613,784,785,786,787,788,789,790,791$, 792 .

Wright, H. E., Jr.: 793 .

Wukelic, G. E.: 203 .

Wunder, Rainer: 794 .

York, J. E.: 568 .

Zienkiewicz, 0. C.: 795 .

Zilinski, R. E., Jr.: 110 .

Zimmerman, D. E.: 439 . 